UNIVERSidAde de SÃo PAUlo

FACULDAdE DE FILOSOFIA, LETRAS E CiênCIAS HumanaS

\title{
As Viagens de Gulliver e a ascensão do romance inglês
}

ROGER MAIOLI DOS SANTOS

\author{
Dissertação de mestrado apresentada ao \\ Programa de Pós-Graduação na área de \\ Estudos Lingüísticos e Literários em Inglês \\ do Departamento de Letras Modernas \\ da Faculdade de Filosofia, Letras e Ciências Humanas \\ da Universidade de São Paulo
}



UniVersidade de São PaUlo

Faculdade de Filosofia, Letras E CiênCias Humanas

\section{Roger Maioli dos SANTOS \\ As Viagens de Gulliver \\ e a ascensão do romance \\ inglês}

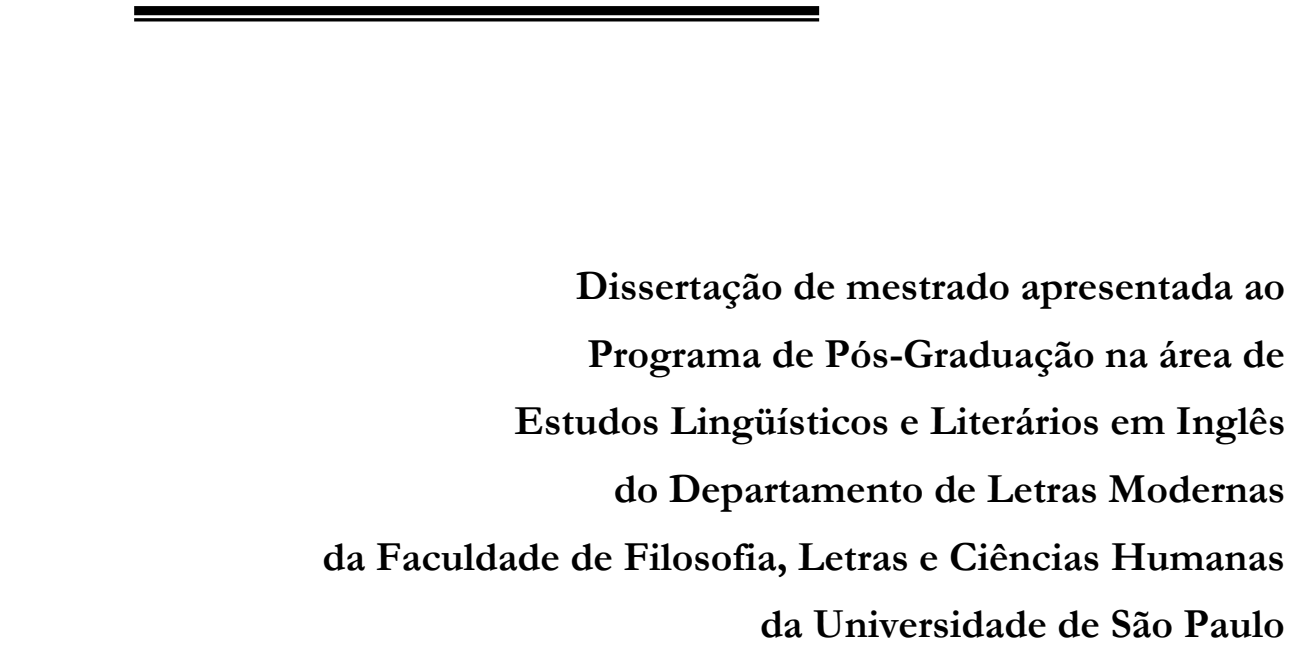

Orientador: Prof. Dr. Marcos César de Paula Soares

SÃO PAULO

2006 


\section{Resumo}

Este é um estudo das relações entre As Viagens de Gulliver e o romance inglês em sua fase de formação.

Em 1726, quando Gulliver foi originalmente publicado, o romance inglês não era ainda um gênero consolidado, mas os elementos formais que o caracterizariam já circulavam em outras formas literárias. Esses elementos formais - como a contemporaneidade, a probabilidade, a ênfase na realidade quotidiana, a rejeição de enredos tradicionais, a linguagem referencial e o individualismo - associavam-se então a correntes literárias e valores progressistas inaceitáveis para Swift.

Em As Viagens de Gulliver, Swift se apropriou dessas exatas convenções para atacar por dentro tais correntes e tais valores. Em outras palavras, Gulliver constituiu (entre muitas outras coisas) uma paródia intermitente das tendências formais que com o tempo viriam a caracterizar o romance moderno. E no ato mesmo de se apropriar das convenções que combatia, Swift contribuiu para o estabelecimento de uma via alternativa para autores mais tradicionais.

Palavras-chave: Swift; Gulliver; literatura inglesa; romance; paródia. 


\section{Abstract}

This is a study of the relationships between Gulliver's Travels and the English novel in its formative stage.

When Gulliver was originally published in 1726, the English novel was not yet a consolidated genre, but the formal elements that would eventually characterise it were already circulating via other literary forms. Such formal elements - e.g. contemporaneity, probability, emphasis on daily reality, the rejection of traditional plots, referential language and individualism — were then associated with literary trends and progressive values deemed unacceptable by Swift.

In Gulliver's Travels, Swift appropriated these very conventions in order to attack from within such trends and values. In other words, Gulliver amounted (among many other things) to an intermittent parody of the formal trends that would in time characterise the modern English novel. And in the very act of appropriating the conventions he were fighting against, Swift furthered the establishment of an alternative avenue for more traditional writers.

Keywords: Swift; Gulliver; English literature; novel; parody. 


\section{Índice}

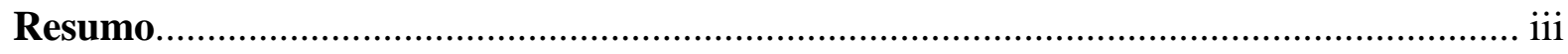

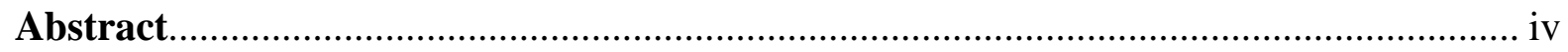

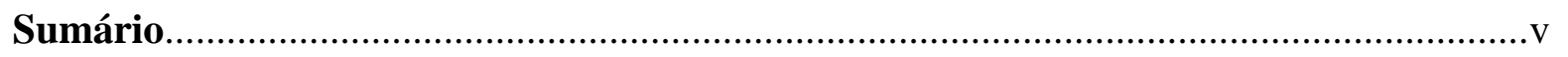

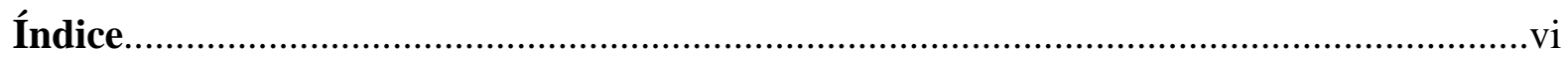

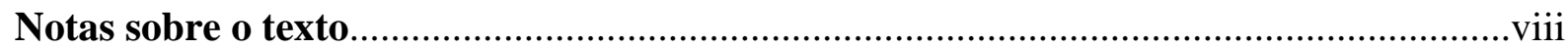

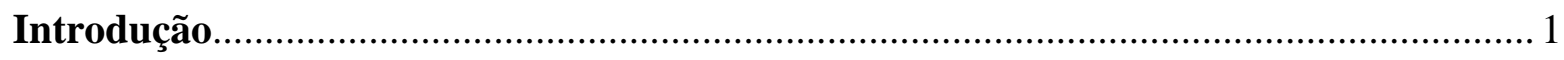

PARTE 1: NORMAS E EXCEÇÕES....................................................................

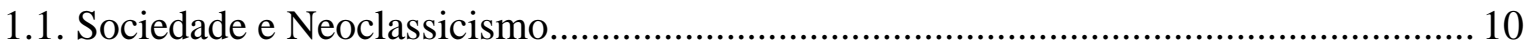

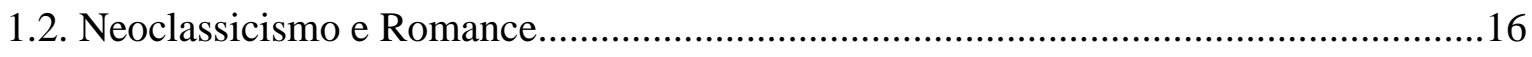

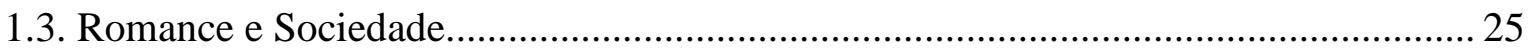

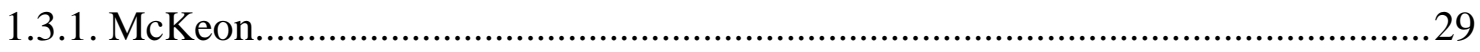

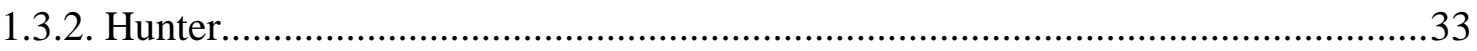

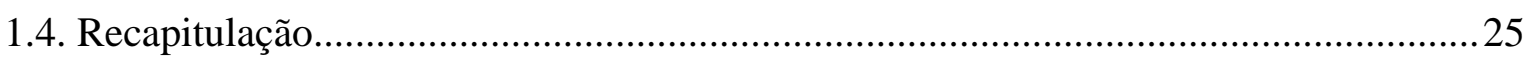

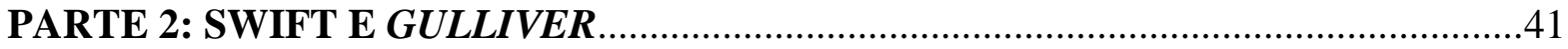

2.1. As Raízes de Gulliver.................................................................................. 42

2.1.1. Raízes Políticas.......................................................................................... 43

2.1.2. Raízes Literárias...................................................................................... 49

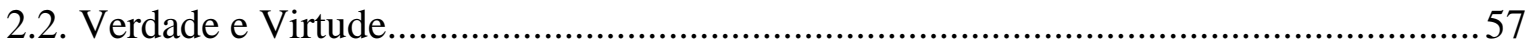

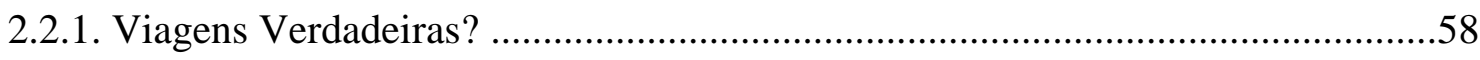




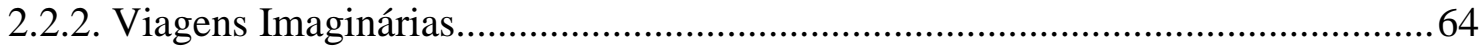

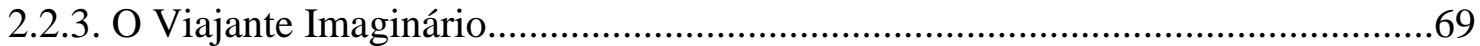

2.2.4. A Alternativa Conservadora....................................................................... 76

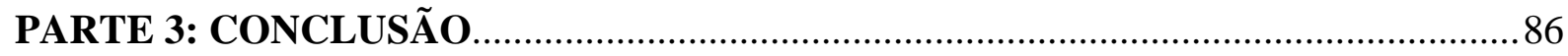

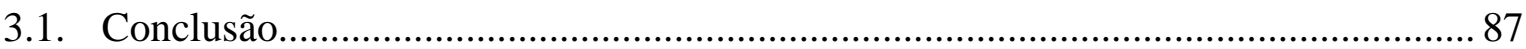

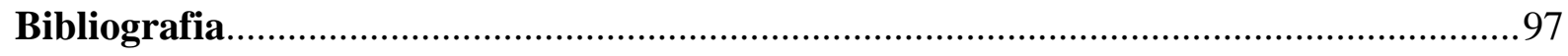




\section{Notas sobre o texto:}

a) Evitei citar em outros idiomas. As citações serão traduzidas e terão seu original registrado no rodapé.

b) Adotei as seguintes abreviaturas para as notas de rodapé (ver dados completos na Bibliografia):

CCJS: The Cambridge Companion to Jonathan Swift, edição de Christopher Fox

CCEN: The Cambridge Companion to the Eighteenth-Century Novel, edição de John Richetti

EECE: Eighteenth-Century Critical Essays, edição de Scott Elledge

GGT: The Genres of Gulliver's Travels, edição de Frederik N. Smith

GT: $\quad$ Gulliver's Travels, edição crítica de Albert J. Rivero

MMS: The Memoirs of the Extraordinary Life, Works, and Discoveries of Martinus Scriblerus, edição crítica de Charles Kerby-Miller

TCH: Swift: The Critical Heritage, coletânea de textos de época editada por Kathleen Williams

WJS: The Writings of Jonathan Swift, edição crítica de Robert A. Greenberg e William Bowman Piper 


\section{Introdução}

Desde que passei a me ocupar com estudos sobre a origem do romance inglês, tornou-se comum que as pessoas me perguntem: e Gulliver, como fica nessa história? Em algum momento observei que a resposta exigiria todo um volume. Este é o volume.

Publicadas em 1726, As Viagens de Gulliver já ganharam muitíssimas classificações: romance, sátira narrativa, conto picaresco, viagem imaginária, utopia, antiutopia — e a lista prossegue $^{1}$. A incerteza resulta não somente da falta de estabilidade taxonômica que caracterizou a prosa de ficção na primeira metade do século XVIII, mas também da variedade de modelos a que Swift recorreu na composição do livro. Em Gulliver confluem elementos, por exemplo, de Sir Thomas More, Rabelais, William Dampier e Daniel Defoe — escritores com intenções e métodos tão distintos que dificilmente poderíamos abrigá-los sob um toldo comum. A reunião dessas fontes fez de Gulliver um livro de muitas faces, desafiando a classificação categórica e relegando a obra a um estado de flutuação genérica que perdura até hoje. Ao passo que a posterior distinção dos gêneros concedeu a Robinson Crusoé um lugar assegurado na gênese do romance moderno, Gulliver ainda erra pelas margens da história literária, e tão cedo não promete lançar âncora.

A promiscuidade genérica de Gulliver é também a de seu autor. Jonathan Swift (16671745) não se notabilizou pela prática de nenhuma forma consagrada. Membro da esfera culta numa época em que a tradição neoclássica começava a dar mostras de esgotamento e as novas opções formais eram pouco convidativas para o escritor de formação, Swift descobriu-se sem modelos certos a seguir. Seu primeiro biógrafo, o conde de Orrery, observou que ele “escrevera miscelaneamente, e optara antes por parecer um cometa errante que uma estrela fixa. Houvesse aplicado as faculdades de sua mente numa obra grande e útil, e ele teria

\footnotetext{
${ }^{1}$ Para uma relação mais completa, ver Frederick N. Smith, “Introduction”. GGT, P. 20.
} 
decerto brilhado com mais glória”². Não bastasse as formas disponíveis na época parecerem desgastadas ou vis, Swift, por sua conta, parece haver duvidado cronicamente da virtude intrínseca das obras de imaginação. Se chegou a aplicar a sério as faculdades de sua mente, não foi na literatura imaginativa: ele era acima de tudo um escritor político que punha a escrita a serviço de uma causa ulterior, e que via pouco valor autônomo nos frutos literários dessa campanha, aos quais raramente apunha seu nome. Se algum gênero lhe parecia sobressair aos demais, era a história. Ele almejou destacar-se como historiador da Inglaterra e especialmente do reinado de Ana, mas seus ocasionais esforços historiográficos não lograram êxito. Seus demais escritos são amiúde efemeridades em que se reconhece a voz do historiador e comentarista político. Assim também As Viagens de Gulliver: longe de revelarem uma eventual crença no valor artístico da prosa de ficção, elas constituíram a adoção de um modelo socialmente significativo que permitiria a Swift dar vazão a seus interesses centrais nos planos simultâneos da forma e do conteúdo. Com o tempo a motivação política do livro esmaeceria e seria obscurecida pelo mero interesse narrativo, em resultado do que Swift entraria para a história da literatura inglesa como um ficcionista malgré lui. O público em geral não estranharia ver Robinson Crusoé e As Viagens de Gulliver ombreando em séries juvenis e coleções de romances famosos. A crítica especializada, porém, não perderia de vista a atitude de Swift para com a prosa de ficção — uma atitude a um só tempo de adoção e repúdio - , nem a complexa relação de As Viagens de Gulliver com o emergente romance inglês.

O leitor, com boa razão, desejará saber o que tenho em mente ao me referir ao "romance”. Por motivos que ficarão claros mais adiante, não pretendo adotar uma definição restritiva do termo, que rotule impecavelmente o universo de obras. Por enquanto apresento uma definição sucinta, que será complementada na Parte 1 por uma descrição operacional do gênero. Tanto a definição como a descrição são de J. Paul Hunter. O romance

\footnotetext{
2 "[Swift has written miscellaniously, and has chosen rather to appear a wandering comet, than a fixed star. Had he applied the faculties of his mind to one great, and useful work, he must have shined more gloriously." Remarks on the Life and Writing of Dr. Jonathan Swift, Dean of St. Patrick's, Dublin (1752) TCH, P. 116.
} 
é uma espécie distinta (e então bastante inovadora) de prosa de ficção — denotando a preocupação com a subjetividade e a consciência de pessoas comuns, com a linguagem comum e com eventos quotidianos e contemporâneos - que emergiu na Europa em vários pontos dos séculos XVI e XVII e começou a dominar o mercado popular na Inglaterra no início do século XVIII, pouco antes de Swift escrever As Viagens de Gulliver. ${ }^{3}$

Essa definição, a princípio bastante ampla, é também suficientemente precisa para dar ao gênero fronteiras mais ou menos definidas. Tais fronteiras podem parecer arbitrárias, sobretudo para nós, leitores de nosso tempo e idioma. Isso se deve a um problema terminológico que sempre se impõe aos que escrevem em português sobre o romance de língua inglesa. O tipo de obra narrativa que atualmente chamamos de romance - digamos, Mrs. Dalloway ou O Complexo de Portnoy — é designado em inglês pela palavra novel. Esse termo, entretanto, não tem o sentido amplo de sua contrapartida em português. Em seu uso substantivo, o nosso "romance" pode se aplicar tanto a poemas do círculo arturiano, ao Roman de la Rose e às longas narrativas heróicas de Madelleine de Scudéry como a obras de Dickens, Flaubert ou Dostoiévski. A palavra novel, se usada com rigor, só vale para o segundo grupo, e exclui de antemão composições em verso e o mundo maravilhoso da lenda. Quando discorremos em português — ou mesmo em francês ou italiano — sobre a ascensão inglesa do romance, roman ou romanzo, precisamos qualificar nossos termos. Podemos fazêlo pelo recurso a um epíteto: a versão italiana de The Rise of the Novel, por exemplo, se intitula Le Origini del Romanzo Borghese. Eu preferi utilizar pura e simplesmente "romance”, ressalvando porém que o termo deve ser entendido o tempo todo como uma tradução literal de novel, com as restrições de sentido que isso implica: “a preocupação com a subjetividade e a consciência de pessoas comuns, com a linguagem comum e com eventos quotidianos e contemporâneos".

\footnotetext{
3 "[The novel] is a distinctive (and then quite innovative) kind of prose fiction - featuring a concern with subjectivity and the consciousness of ordinary people, ordinary language, and everyday contemporary events that emerged in Europe at various points in the sixteenth and seventeenth centuries and that began to dominate the popular market in England in the early eighteenth century, shortly before Swift wrote Gulliver's Travels.” J. Paul Hunter, “Gulliver's Travels and the later writings”. In: CCJS, p. 238, n. 18.
} 
A especificidade do termo na Inglaterra é um resultado dos esforços críticos que se fizeram desde o final do século XVII para diferenciar a novel de um outro gênero bastante amplo que, para o nosso infortúnio, os ingleses chamam de romance. A palavra designa sobretudo o que conhecemos como o romance heróico ou idealista da França, com seu recurso ao maravilhoso, seu decoro cortesão e seus heróis nobres, em nítido contraste com a realidade mais prosaica da novel. Também designa a atitude anti-realista que voltaria a ter vigência com o movimento gótico e o Romantismo. Já se vê que problemas isso cria para o tradutor: textos como o prefácio de Nathaniel Hawthorne em A Casa das Sete Torres, no qual o autor faz distinções entre novel e romance, chegam ao português empregando os cognatos "novela” e “romance”. A leitura fica mais fluente, mas o sentido padece. Um estudo crítico não pode correr esse risco. Como já reduzi a abrangência do português "romance” para criar um equivalente instrumental de novel, adotarei como tradução do inglês romance a expressão “estória romanesca” ou a forma reduzida "romanesco”, seguindo nisso o exemplo de Sandra Vasconcelos ${ }^{4}$.

Na primeira metade do século XVIII a distinção entre romance e estória romanesca ainda não se assentara, e as expressões eram usadas sem nenhum critério consensual, sendo por vezes intercambiáveis. Pior: a elas vinham somar-se muitas outras designações, como “história”, “memória” e “epopéia”. Esses termos eram aliás preferíveis: na virada do século XVII para o XVIII o termo romance (novel) estava por demais associado ao escândalo de autoras malvistas como Aphra Behn e Mary Delariviere Manley para que escritores de ambição o adotassem. No pós-escrito a Clarissa, Richardson tratou de desenganar os que vissem em seu livro "um mero romance ou estória romanesca”5. Fielding, por seu turno, conclamou para si o campo do "épico cômico em prosa” e da "história (...), diferente do enxame de tolos romances e monstruosas estórias romanescas”. Entre os romancistas canônicos anteriores a 1770, somente Smollett admitiu em algum momento escrever romances, na dedicatória de The Adventures of Ferdinand Count Fathom (1753). E todavia o mesmo Smollett considerava The Adventures of Roderick Random (1748) uma estória

\footnotetext{
${ }^{4}$ Sandra Guardini Vasconcelos, Dez lições sobre o romance inglês do século XVIII, p. 35.

5 “(...) a mere novel or romance”. Clarissa, p. 1498.

${ }^{6}$ Cf. prefácio a Joseph Andrews e Tom Jones, IX, I (“Swarm of foolish Novels, and monstrous Romances” ).
} 
romanesca, apesar de a estrutura dos dois livros ser muito similar.

Essa confusão terminológica não era apenas má vontade: antes de a noção do romance coalescer na segunda metade do século XVIII, os romancistas ingleses não se viam necessariamente numa empreitada comum. “[L]onge de estarem prontos a aceitar as variadas obras como 'romances', eles não parecem ter chegado nem mesmo ao consenso de que obras como Robinson Crusoé, Pamela, Joseph Andrews, Clarissa, Tom Jones, Peregrine Pickle e Tristram Shandy eram todas da mesma espécie”7 . Em outras palavras, o romance inglês não nasceu de um projeto formal elaborado em comunhão por um conjunto de autores de vanguarda. A teorização neste caso, como em muitos outros, foi posterior à prática: o conceito do gênero só se estabilizou após um elevado grau de experimentação por parte de autores que seguiam por trilhas paralelas mas distintas. Nossos esforços por conferir maior nitidez às fronteiras genéricas esbarram no fato de que livros muito diferentes se consagraram como romances numa época em que os termos vinham se assentando mas o gênero era relativamente amorfo. A menos que estejamos dispostos a rejeitar uma parte dessas obras digamos, Tom Jones ou Tristram Shandy —, as definições que propusermos precisam ser suficientemente flexíveis para acomodar toda a gama de experimentação que precedeu a estabilização terminológica. Eis por que evitei adotar uma definição restritiva de romance: nenhum modelo rígido de formulação posterior poderá dar conta da instabilidade e da fluidez genérica então prevalecentes.

Uma conseqüência dessa abordagem mais maleável à origem do romance é que teremos de renunciar à idéia de obra fundadora. Tal idéia, especialmente grata ao jornalismo cultural, é de qualquer modo pouco criteriosa. A eleição de um primeiro romance costuma ser influenciada por preferências pessoais ou nacionais, e decidida graças a definições genéricas elaboradas com o fito de excluir predecessores. Isso ocorre porque à classificação como romance apega-se usualmente um juízo de valor: numa época que prefere a inovação ao tradicionalismo, ser o primeiro romance significa sobressair na grande corrente literária e prenunciar o futuro. Mais que isso: o julgamento da primazia é feito quase sempre com base

\footnotetext{
7 “[F]ar from being ready to accept the various works as 'novels,' they do not appear to have arrived at a consensus that works such as Robinson Crusoe, Pamela, Joseph Andrews, Clarissa, Tom Jones, Peregrine Pickle and Tristram Shandy were even all of the same species”. Geoffrey Day, From Fiction to the Novel, p. 7.
} 
no cânone, como se o primeiro fosse necessariamente o famoso. Os candidatos a romance fundador incluem invariavelmente obras canônicas: Satyricon, O Asno de Ouro, Filocolo, Pantagruel, A Celestina, Lazarillo de Tormes, Dom Quixote, A Princesa de Clèves, Robinson Crusoé, Pamela, Joseph Andrews. Temos aí uma confusão entre precedência e preeminência, e ela é prejudicial ao estudo sério de origens. O cânone é um instrumento útil na medida em que permite ao crítico manusear um corpus universal vasto demais para ser abarcado em sua inteireza. Em Mimesis, por exemplo, Erich Auerbach optou conscientemente por trabalhar com autores canônicos (salvo algumas exceções), em razão do imenso intervalo histórico que lhe coube por objeto. Mimesis, em sua busca pela "unificação da quotidianidade com a

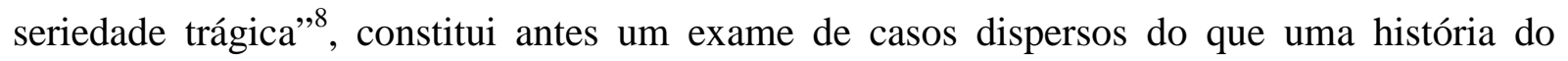
realismo europeu ${ }^{9}$, já que Auerbach deixa de lado não somente autores de menor vulto (como Robert Challe e George Lillo), mas também figuras importantes como Samuel Richardson, tratando sumariamente de outros como Calderón e Lope ${ }^{10}$. Essa opção, válida para a proposta de Mimesis, é menos justificável num estudo de origens. Nesse caso devemos ter em mente que o cânone representa um recorte seleto de um universo muito mais amplo, e que nesse processo de redução ele agiganta a singularidade das obras, conferindo uma nitidez enganosa às fronteiras formais da história e favorecendo o estabelecimento da precedência em tal ou qual gênero. É evidente que se limitarmos nosso exame a Shakespeare, Donne, Milton e Defoe, este último será o fundador do romance. A certeza desaparece quando trazemos à mesa a grande e multifária produção que acompanhou Robinson Crusoé e que partilhou em muitos momentos de suas características formais, por vezes antecipando-as. A eleição segura de um primeiro romance, portanto, só pode ocorrer com a simplificação do processo histórico. Os dois críticos com quem minha presente dívida é maior — J. Paul Hunter e Michael McKeon — - em que pesem suas divergências, coincidem na proposta de expandir o leque de estudo e considerar obras não canônicas e até mesmo "extraliterárias”, no esforço por resgatar a real complexidade da gênese do romance.

Como se vê, nosso território é bravio. Ele não possui fronteiras marcadas nem

\footnotetext{
${ }^{8}$ Erich Auerbach, Mimesis, p. 246.

${ }^{9}$ Idem, p. 493.

${ }^{10}$ Ibidem, p. 296.
} 
compartimentos estanques. Ao longo das páginas seguintes, o início do século XVIII será visto como um momento literário prolífico e genericamente instável, em que as narrativas em prosa podem participar simultaneamente de muitos gêneros - do romance, do romanesco, da utopia, das biografias criminais, das alegorias religiosas, da viagem imaginária — sem se deixarem reduzir a nenhum deles; e não haverá um teste de DNA que lhes determine a pureza de sangue, nem identifique o primeiro romance genuíno. O risco de que esse ofuscamento das fronteiras ponha em dúvida o processo mesmo de ascensão de um novo gênero é ilusório. Nas palavras de Hunter:

[O] moderno romance inglês, como o conhecemos, ganha existência em algum momento no início do século XVIII, e eu afirmaria que a quantidade explosiva de ficção narrativa na época, juntamente com mudanças distintas e definíveis na natureza da narrativa extensa, significam que podemos especificar a emergência de um gênero mesmo que não a possamos fixar numa tarde qualquer de sexta-feira. ${ }^{11}$

Após essas considerações preliminares, o leitor já terá previsto que meu objetivo aqui não será restituir As Viagens de Gulliver ao seio do romance, problema que se poderia resolver com uma definição do gênero desenvolvida especificamente para esse fim. Isso equivaleria, no entanto, a mudar o idioma da discussão crítica e impossibilitá-la na prática. Meu interesse está antes em estudar as relações entre As Viagens de Gulliver e esse gênero cujos contornos ainda eram incertos mas cujas tendências particulares já se revelavam. O estudo se dividirá em duas partes, com uma conclusão ao final. A Parte 1, que tratará muito pouco de Swift em si, procurará retratar a posição do romance no início do século XVIII, como um gênero sem regra e sem prestígio numa época de normas neoclássicas e preponderância de escritores pertencentes ou vinculados à aristocracia. A Parte 2 inserirá

\footnotetext{
11 " [T] $]$ he modern English novel as we know it comes to exist sometime around the beginning of the eighteenth century, and I would argue that the exploding amount of narrative fiction then, together with distinctive and definable changes in the nature of extended narrative, mean that we can specify the emergence of a genre even if we cannot pin it down to a particular Friday afternoon." J. Paul Hunter, “Gulliver's Travels and the Novel”, p. 70 .
} 
Swift no contexto descrito na Parte 1, estabelecendo relações entre As Viagens de Gulliver e o romance em formação; entre Swift e os novos romancistas; e entre a esfera conservadora daquele e a esfera progressista a que estes freqüentemente pertenciam.

Se Swift percebia os rumos que a prosa de ficção vinha tomando, de que maneira suas inclinações se espelham em sua única incursão prolongada por esse terreno? Em outras palavras, “e Gulliver, como fica nessa história?” Veremos como esse livro reflete e incorpora problemas mais gerais da história literária e social de seu tempo, ilustrando toda uma atitude de classe e de época com relação a um notório arrivista. 
PARTE 1

Normas e exceções 


\subsection{Sociedade e neoclassicismo}

A estória romanesca cujo espaço o romance viria pouco a pouco a ocupar não era senão um nicho menor da literatura aristocrática. O momento que testemunhou a publicação de As Viagens de Gulliver pertencia não à “Era do Romance”, nem à “Era do Romanesco”, e sim ao que desde há muito se convencionou chamar de Era Augustana - um período histórico e cultural que se espelhava na pujança do Império Romano na época de Augusto e no prestígio de luminares das letras como Virgílio, Horácio e Cícero; uma fase em que a política e a literatura eram regradas por princípios de ordem maior — uma aristocracia ilustrada no primeiro caso e normas neoclássicas no segundo. Essa, ao menos, é a definição estereotípica; não lhe faltam problemas, como veremos em seguida.

O período que a expressão "Era Augustana” designa é a primeira incerteza. O clássico estudo de Arthur Humphreys traz uma delimitação no subtítulo: The Augustan World-Life and Letters in Eighteenth-Century England. Humphreys se concentra no século XVIII mais exatamente até seus meados — e deixa de lado o intervalo entre 1660 e 1702 (respectivamente a Restauração e a ascensão da rainha Ana). Scott Elledge, em sua antologia de ensaios críticos da época, cita a que lhe parece a menção mais antiga da expressão num texto de Leonard Welsted datado de 1720: "vejo elevar-se uma nova Era Augustana”12. A. C. Ward buscará uma fonte posterior, mas com uma conseqüência interessante: a seu ver a idéia de "augustanismo" tem origem numa passagem da biografia de Dryden escrita por Johnson: “O que se disse de Roma, adornada por Augusto, pode aplicar-se mediante uma fácil metáfora à poesia inglesa embelezada por Dryden: lateritiam invenit, marmoream relinquit, ele a encontrou tijolos e a deixou mármore”13. Isso faria recuar a Era Augustana ao século XVII, de modo a englobar a obra de Dryden e de outros autores que instauraram a "correção" poética após a exuberância desregrada dos poetas metafísicos. E, de fato, encontramos uma passagem

\footnotetext{
12 “I see arise a new Augustan Age”. Welsted, “An Epistle to the Duke of Chandos”. In ECCE, p. 548, n. 1.

13 "What was said of Rome, adorned bu Augustus, may be applied by an wasy metaphor to English poetry embellished by Dryden, lateritiam invenit, marmoream relinquit, he found it brick, and he left it marble." Life of Dryden. V. A. C. Ward, Illustrated History of English Literature, v. II, p. 77.
} 
anterior à de Welsted num texto de 1690 escrito por Francis Atterbury, bispo de Rochester: “[Waller] ocupa sem dúvida o primeiro lugar na lista de refinadores e, até onde sei, também o último; pois pergunto-me se no reinado de Carlos II o inglês não atingiu sua plena perfeição e não teve sua Era Augustana, como a teve o latim”14. A delimitação da Era Augustana é assim variante: ela é ora situada no período 1660-1700, ora no período 1700-1740. Resolver a inconsistência cabe naturalmente a especialistas na área. Eu, por prudência - e também porque pretendo tratar do credo neoclássico que regrou grande parte da produção augustana —, optei por trabalhar com os extremos $1660-1740^{15}$.

A Era Augustana, comecei dizendo, representa não somente um período cultural, mas também uma fase da história política e social da Inglaterra. A estratificação entre aristocratas, capitalistas e pobres parecia corresponder a uma tripartição romana similar, e a grandeza da nova Inglaterra queria refletir a de Roma. Mas a justiça do paralelo foi desde cedo posta em dúvida. Voltaire lhe aplicaria sua usual verve: “Há um senado em Londres cujos membros são em parte suspeitos - embora seguramente por engano — de vender ocasionalmente suas vozes, como se fazia em Roma; eis aí toda a semelhança” ${ }^{16}$. A coincidência de estratos sociais era ademais irrelevante, sendo característica “de todas as sociedades mais avançadas onde ainda não teve início o processo de igualização” ${ }^{17}$. Ainda mais problemática é a suposta visão de Augusto como ideal de governante e patrono das letras. Howard D. Weinbrot coligiu todo um volume de evidências de que os “augustanos” viam em Augusto um tirano da pior espécie: covarde, traiçoeiro, opressivo e depravado, responsável por solapar o equilíbrio constitucional da república. O mito de um Augusto sábio e virtuoso - mito que tinha suas altas e baixas conforme oscilava o prestígio do rei - seria uma ficção invocada por poetas com finalidades retóricas ou em busca de patronato régio. Para Weinbrot, o rótulo “augustano” (que deveria aliás ser descartado) é enganoso até mesmo no campo da literatura. A reputação dos luminares

\footnotetext{
${ }^{14}$ [Waller] undoubtedly stands first in the List of Refiners, and for ought I know, last too; for I question whether in Charles the Second's Reign, English did not come to its full perfection; and whether it has not had its Augustan Age, as well as the Latin." Francis Atterbury, "Preface to The Second Part of Waller's Poems". In David Womersley (ed.), Augustan Critical Writing, p. 121.

${ }^{15}$ Sigo o exemplo de Bonamy Dobrée. English Literature in the Early Eighteenth Century, p. 17.

16 “Il y a un sénat à Londres dont quelques membres sont soupçonnés, quoique à tort sans doute, de vendre leurs voix dans l'occasion, comme on faisait à Rome; voilà toute la ressemblance.” Voltaire, Lettres Philosophiques, VIII, p. 63.

${ }^{17}$ Hauser, História Social da Arte e da Literatura, p. 536.
} 
clássicos, sobretudo Virgílio, sofreu em razão dos elogios que haviam feito a Augusto. A Eneida foi vista por muitos como um poema político que preconizava a monarquia. Horácio sofreu críticas similares, e Cícero foi tido como um cego que não percebera nutrir seu futuro executor $^{18}$. Por tudo isso, cumpre usar com certa reserva o nome "Era Augustana”; ele é conveniente, mas não é preciso. E contudo, apesar das imperfeições, ele é muito revelador se dele depreendermos uma relação estreita entre literatura e alta sociedade.

Raramente na história da literatura inglesa a corte exerceu tamanha influência sobre os autores como na época de Carlos II. O interesse sincero do monarca pelo assunto (especialmente pelo drama) incentivou o desenvolvimento de círculos letrados no seio da aristocracia, e é notável o número de nobres então capacitados a escrever com distinção e elegância - como o duque de Buckingham e o conde de Roscommon. Com ocasionais exceções (como Bunyan e Milton), os grandes autores da Restauração foram membros da alta sociedade ou integrantes da classe média cuja educação refinada lhes permitiu o acesso às camadas superiores $^{19}$. O circuito fechado da produção e consumo da literatura palaciana foi muito propício para o desenvolvimento do etos refinado que notabilizou a época. Por um lado, os patronos permitiam aos autores dedicar-se à criação poética sem se preocupar com questões mundanas como a vendagem; por outro, os autores estavam em contato direto com um público composto por connoisseurs cujas expectativas conheciam e cujas críticas ouviam em primeira mão. Essa reciprocidade tinha como resultado uma censura informal, que excluía do escopo da literatura tudo o que fosse ofensivo às altas camadas — sobretudo as camadas baixas. A vida quotidiana (esse reduto de artesãos, vielas urbanas, rixas de família, ambições burguesas e aromas indóceis) só poderia figurar na literatura como objeto de ridículo, não merecendo tratamento sério de autores que tinham na polidez uma de suas máximas. Ilustração literal disso é a passagem de Absalom and Achitophel em que Dryden se recusa a nomear os rebeldes rasteiros: “Tampouco a turba abjeta terá aqui lugar / A quem reis não deram títulos, e nem Deus graça”20. A Restauração, vista como um retorno à ordem política depois dos anos atrozes de Guerra Civil e Commonwealth, seria associada também à

\footnotetext{
${ }^{18}$ Weinbrot, Augustus Caesar in “Augustan” England, p. 50, 126 e 12.

${ }^{19}$ Ver James Sutherland, English Literature of the Late Seventeenth Century, pp. 25-31.

20 "Nor shall the rascal rabble here have place, / Whom kings no title gave, and God no grace.” Dryden, Absalom and Achitophel, 579-580. In Hammond (ed.), Restoration Literature: An Anthology, p. 55.
} 
reordenação literária. Dryden, para quem uma das causas da impolidez elisabetana fora justamente a distância entre escritores e nobres, referiu-se aos elisabetanos como "a raça gigante anterior ao dilúvio"21 — expressão que sugere grandeza mas também grosseria. Recorde-se que os dramaturgos elisabetanos escreviam tanto para a fina flor como para a gente de poucas letras que ia buscar algum regalo nos teatros, e tinham de servir a ambas. Os augustanos só serviriam à primeira. Preservar a grandeza mas refinar o tom foi seu projeto maior. E seu manual de etiqueta foi o neoclassicismo.

A corte que se formou em torno de Carlos II após a Restauração incluía muitos ingleses que se haviam instalado na França durante os anos da Guerra Civil e se imbuído da cultura e dos valores franceses; também incluía franceses pertencentes ao séquito da rainha-mãe Henriqueta Maria. O pensamento crítico francês, então numa fase de intensa atividade, trasladou-se com eles para a Inglaterra e aí ganhou corrência. A literatura nacional seria medida de acordo com princípios que ferventaram na França entre 1630 e 1660 e ganharam sistematização durante o reinado de Luís XIV. Esses princípios, que só muito mais tarde seriam chamados de "neoclássicos”, teriam vasta influência nos séculos XVII e XVIII e serviriam por muito tempo como pedra de toque da boa poesia. Durante o Renascimento, intérpretes italianos e franceses da poética clássica se haviam incumbido de preencher as lacunas dos textos antigos (sobretudo o de Aristóteles) e formular regras abrangentes para a composição e o julgamento da poesia. A França do século XVII sistematizou essas regras e tornou-se o centro difusor do pensamento neoclássico. O princípio supremo desse pensamento era a função moralizante da poesia, que se sobrepunha a seu valor como objeto de deleite; em termos modernos, a função didática das obras era mais importante que sua função estética. Outros princípios gerais eram a linguagem clara, o conteúdo decoroso, a verossimilhança da fábula, a unidade de concepção e a consistência na caracterização dos personagens. Para tudo isso a imitação dos antigos — ou da “natureza” — era essencial. A tragédia clássica, conforme descrita por Aristóteles e Horácio e normatizada pela crítica renascentista, seria o

\footnotetext{
21 “(...) the giant Race before the Flood”. “To my dear friend Mr. Congreve, on his comedy called The Double Dealer" (1694). Ver também o tratamento dado a Shakespeare e Jonson em Of Dramatick Poesie: An Essay (1668).
} 
grande modelo a ser seguido nos misteres da caracterização ${ }^{22}$ e da unidade ${ }^{23}$, com o resultado de que todo detalhe secundário seria visto como excrescência. O importante, segundo esse sistema, era tratar de verdades universais, e não de particularidades geográficas ou históricas. Shaftesbury observaria: “O mero retratista, com efeito, tem pouco em comum com o poeta; antes, como o mero historiador, ele copia o que vê e traça minuciosamente toda feição e marca abstrusa; não é assim com homens de invenção e engenho”24. Depois dessas regras gerais, a doutrina neoclássica apresentava outras, mais específicas, que regravam os diversos tipos poéticos, especialmente a comédia, a tragédia e a epopéia. A violência explícita da tragédia elisabetana, por exemplo, seria banida para os bastidores, e toda ação extravagante deveria ser narrada em vez de encenada ${ }^{25}$. Descontadas ocasionais divergências, tal era a essência do pensamento neoclássico que os ingleses receberam da França ${ }^{26}$.

Grande parte dos princípios neoclássicos parecia aos augustanos saudável e conforme ao bom senso. De fato, após sua sistematização no último quartel do século, o neoclassicismo se tornou o credo ortodoxo. Mas a intransigência das regras menores (e especialmente das unidades de ação, tempo e lugar) era vista como um obstáculo à inventividade. Essa objeção já vinha sendo feita na própria França por autores como La Bruyère, Saint-Évremond e o Corneille da fase final, de modo que o neoclassicismo que desembarcou na Inglaterra foi logo acompanhado de sua crítica. O crescente interesse por Longino, cujo tratado Do Sublime se difundiu na tradução de Boileau, favoreceu uma atitude mais liberal no julgamento poético. “[D]evemos preferir uma grandeza com alguns defeitos, ou uma mediocridade correta, em tudo sã e impecável?” Os ingleses, que tinham sempre presente a obra de Shakespeare como prova de que era possível ser grande sem ser exato, se dispuseram à tolerância. “[A] precisão

\footnotetext{
22 "Quando se experimenta assunto nunca tentado em cena, quando se ousa criar personagem nova, conserve-se ela até o fim tal como surgiu de começo, fiel a si mesma.” Horácio, op. cit., p. 59. (As citações da poética antiga provêm do volume A Poética Clássica, em que Roberto de Oliveira Brandão reuniu os textos de Aristóteles, Horácio e Longino.)

23 “Em suma, o que quer que se faça seja, pelo menos, simples, uno.” Horácio, Arte Poética, p. 55. Ver também Aristóteles, Poética, VIII, p. 28.

24 "The mere face painter, indeed, has little in common with the poet but, like the mere historian, copies what he sees and minutely traces every feature and odd mark. It is otherwise with the men of invention and design.” Shaftesbury, "Sensus Communis", in Characteristics of Men, Manners, Opinions, Times (1711). In ECCE, p. 174.

${ }^{25}$ Horácio, op. cit., p. 60.

${ }^{26}$ Atkins, English Literary Criticism: $17^{\text {th }}$ and $18^{\text {th }}$ Centuries, pp. 11-12.
} 
em tudo acarreta o risco da mediania, e nos grandes gênios, assim como na excessiva riqueza, alguma coisa se há de negligenciar.”27 Essa idéia seria ecoada em muitos ensaios de autores da época. Por isso é necessário que evitemos a associação não qualificada entre augustanos e neoclassicismo. Mesmo na rara fase em que o ânimo naturalmente indômito dos ingleses se deixou atrair pelo clássico, nenhum dos autores mais influentes acolheu a doutrina sem restrições. Butler, Dryden, Addison, Pope, Johnson — todos os grandes nomes deixaram pronunciamentos contra a servil obediência às regras. O autor que mais se destacou como defensor da ortodoxia neoclássica, Thomas Rymer, acabou estigmatizado como exemplo do mau crítico, sobretudo em razão de seus ataques a Shakespeare. No período que mais nos interessa (o primeiro terço do século XVIII), o que havia era uma aceitação superficial da doutrina de Boileau, Rapin e Le Bossu, com pouco interesse nas regras mais estritas. Mantinham-se os princípios gerais (como o propósito moral da poesia e a imitação dos antigos e suas formas) mas o julgamento de acordo com regras vinha dando lugar ao julgamento de acordo com o gosto. "Em meio a contracorrentes conflitantes já havia um despertar para a necessidade de algo mais que regras, a constatação de que o apelo poético não se dirigia somente ao intelecto, mas também às emoções; e métodos de apreciação, em oposição a métodos de composição, tornaram-se então a consideração principal.”28 Já existiam, portanto, em forma embrionária as tendências estéticas que em meados do século renovariam o interesse no medievalismo e em outras avenidas artísticas e seriam responsáveis por rejeitar até mesmo a face menos restritiva do credo neoclássico. Um exemplo germinal é a série de ensaios sobre os “prazeres da imaginação” publicados no Spectator por Addison — autor que, com seu propósito de tirar a filosofia das universidades e levá-la para os cafés, pode ser visto como uma ponte entre o alto mundo augustano e um outro mundo menos polido e mais prosaico, a cuja expressão literária dedico o próximo capítulo ${ }^{29}$.

\footnotetext{
${ }^{27}$ Longino, Do Sublime, XXXIII, 1-2. Esse tratado, composto na primeira metade do século I, é na verdade de autoria incerta. Ele foi uma réplica a um tratado de Cecílio de Calacte em que este exaltava o valor da correção e da pureza gramatical (o chamado aticismo). É, portanto, um manifesto nato contra a intransigência das normas.

28 "Amid conflicting cross-currents there was already an awakening to the need for something more than rules, a realization that the poetic appeal was not to the intellect alone, but to the emotions as well; and methods of appreciation, as distinct from methods of composition, became now the main consideration.” Atkins, op. cit., 185.

${ }^{29}$ Para os ensaios “On the pleasures of the imagination”, ver os números 411 a 421 do Spectator. A proposta de popularização do conhecimento é feita no Spectator No 10.
} 


\subsection{Neoclassicismo e romance}

Sir Fopling: (...) Tenho intrigas para contar-te, mais agradáveis do que jamais leste num romance.

Harriet: Escreve-as, meu senhor, e apraz a nós mulheres; nossa língua carece de tais estorietas.

Sir Fopling: Escrever, madame, é uma parte mecânica do espírito; um cavalheiro jamais deve ir além de uma canção ou um bilhete. ${ }^{30}$

Sir George Etherege, The Man of Mode, IV, i

Conceitos abrangentes como Era Augustana ou neoclassicismo são decerto úteis, mas não devemos perder de vista suas limitações. No capítulo anterior procurei discuti-las brevemente e evitar a adoção estereotípica dos conceitos, sem entretanto pôr em dúvida o fundo de verdade que eles contêm. No restante do texto usarei o termo “augustano” para designar escritores cultos que pertenciam aos círculos da elite e seguiam uma versão diluída do neoclassicismo. Por isso mesmo não o aplicarei a autores “excluídos” como John Dunton ou mesmo Daniel Defoe ${ }^{31}$.

No início do século XVIII notamos duas mudanças importantes com relação ao augustanismo da Restauração: a progressiva remoção dos nobres do rol de autores e a decadência do patronato, sobretudo após 1714. Com o crescimento do mercado livreiro, a prática profissional da literatura vai se assemelhando a um ofício como qualquer outro, sendo aviltante para o nobre. Mais adiante isso seria fatal para os círculos palacianos, mas em princípios do século a literatura continuava dominada por escritores cultos ligados às altas esferas, e esses escritores se empenhavam em defender a hierarquia dos gêneros neoclássicos.

\footnotetext{
30 "Sir Fopling: I have intrigues to tell thee more pleasant than ever thou read'st in a novel.//Harriet: Write'em, sir, and oblige us women; our language wants such little stories.//Sir Fopling: Writing, madam, 's a mechanic part of wit; a gentleman should never go beyond a song or a billet.” In Lawrence (ed.), Restoration Plays, p. 171.
} 
A tragédia, a comédia e a ode são as formas privilegiadas, e a elas vêm somar-se outras igualmente exigentes em bagagem clássica — como o poema herói-cômico e a "imitação" (a reescritura de poemas antigos com ambientação moderna, como as imitações de Horácio feitas por Pope ou as de Juvenal feitas por Johnson).

É hora então de nos perguntarmos: se os augustanos dominaram de tal forma a cena literária da época, como se explica que tão poucos deles sejam lidos com freqüência pelo público atual? A resposta tem menos a ver com questões elusivas de mérito artístico do que com os imprevisíveis rumos da história da literatura. O prestígio que o romance granjeou a partir do século XIX converteu a prosa de ficção na forma literária por excelência, e é natural que os leitores de nosso tempo procurem nos séculos passados aquilo que mais se assemelhe às preferências modernas. Um autor como Voltaire é mais lido por seus contos filosóficos do que por sua obra poética e histórica, a que ele atribuía muito mais valor. Os títulos dos séculos XVII e XVIII que costumam figurar hoje em dia em coleções populares são, quase que sem exceções, narrativas ficcionais em prosa: O Progresso do Peregrino, Robinson Crusoé, As Viagens de Gulliver, Tom Jones, A História de Rasselas, O Vigário de Wakefield e outros e outros. Nos círculos augustanos, porém, prevalecia a poesia, esteio do neoclassicismo. Antes de 1740, era muito raro que autores de formação clássica praticassem a prosa de ficção; e se o fizessem, faziam-no em escritos de mão sinistra.

Uma das razões para a falta de prestígio dessa forma era a inexistência de um texto autorizador proveniente da Antigüidade. Mesmo na Grécia antiga a prosa de ficção foi um gênero tardio, e não recebeu a mesma atenção crítica que a épica, o drama e a poesia lírica. A Poética de Aristóteles, cuja ênfase em características formais a punha numa posição minoritária em meio à crítica antiga, foi tida não obstante como a autoridade suprema no Renascimento, e seu silêncio sobre a prosa de ficção teve grandes conseqüências ${ }^{32}$. Como vimos, os críticos italianos que acolheram o texto e preencheram-lhe as lacunas converteram as descrições de Aristóteles em prescrições a serem observadas para a prática da real poesia, que foi compartimentada em gêneros com sanção “aristotélica”. Quando um gênero não tinha

\footnotetext{
${ }^{31}$ É comum, contudo, encontrar Defoe listado entre os augustanos. Minha opção de estreitar a aplicação do termo (feita também por J. Paul Hunter e outros) destina-se somente a dar maior clareza ao argumento.

${ }^{32}$ Daniel Javitch, “The Assimilation of Aristotle’s Poetics in sixteenth-century Italy”. In Glyn P. Norton (ed.). The Renaissance, pp. 53-65.
} 
essa sanção nas fontes originais — a exemplo da comédia, cuja descrição mais extensa por Aristóteles possivelmente se perdeu —, autores como Robortello, Castelvetro ou Giraldi a “deduziam” da Poética, aduzindo regras para a composição do gênero. (Desse debate é que surgiram as três unidades da dramaturgia, cuja origem moderna era desconhecida por muitos augustanos.) A dedução de regras, no entanto, se tornava mais difícil no caso de gêneros desconhecidos na Antigüidade, como o romanzo e sobretudo a novella. O romanzo era a princípio uma forma escrita em verso, e as discussões a seu respeito tinham como vórtice o Orlando Furioso de Ariosto. O mundo heróico do Orlando acabaria transplantado para obras compostas em prosa, e o enfoque cavalheiresco seria sucedido posteriormente pelo pastoral e pelo histórico. A busca de aceitação para esse tipo de ficção resultou em tentativas de preservar seu estatuto de poesia. $\mathrm{O}$ argumento era o de que um poema podia perfeitamente ser escrito em prosa — idéia sustentada por autores da expressividade de Tasso (Discorsi del poema eroico) e reformulada posteriormente por Fielding no prefácio de Joseph Andrews. A consagração dos romances bizantinos, e sobretudo da Etiópica de Heliodoro, como grandes poemas em prosa da Antigüidade proporcionou às narrativas romanescas uma genealogia respeitável e uma fase de aceitação crítica, e não foi por acaso que Cervantes viu nos Trabajos de Persiles y Sigismunda seu texto imortalizador. Na França (trajeto lógico da crítica italiana rumo à Inglaterra), as pretensões do roman à posição de epopéia em prosa eram bem conhecidas, e foram sustentadas num tratado seminal: a Lettre-traité sur l'origine des romans (1670), do bispo Pierre-Daniel Huet. Huet afirmava que o roman, como uma espécie de épico, devia observar as regras intrínsecas do gênero; ele conseguiu reconciliar a estrutura episódica do roman com o requisito neoclássico de unidade, e sua idealização com o requisito de verossimilhança. Seu tratado, que foi logo traduzido para o inglês ${ }^{33}$, contribuiu para justificar o prestígio que a estória romanesca desfrutava no século XVII como a variedade de prosa de ficção mais aceita nos meios aristocráticos ${ }^{34}$. Mas a composição do gênero romanesco na Inglaterra foi escassa: o único exemplo de considerável destaque (se excetuarmos o precedente de Sir Philip Sidney) foi a Parthenissa de Roger Boyle (1651-1656/1669). Em geral o interesse dos leitores por esse tipo de ficção era satisfeito por traduções de autores

\footnotetext{
${ }^{33}$ A Treatise of Romance and Their Originals (1672).

${ }^{34}$ Cf. Lionel Stevenson, The English Novel. A Panorama, capítulo II.
} 
franceses como Mlle. de Scudéry e La Calprenède ${ }^{35}$. Depois de 1670 mesmo a produção francesa definhou, e entre os augustanos a forma não parece ter sido praticada. Eu, pelo menos, não sei de nenhum caso.

Menos afortunado que o destino do romanzo foi o da novella italiana. Embora elogios às virtudes poéticas da prosa de Boccaccio não fossem incomuns, a aproximação dessa forma com os gêneros consagrados mostrou-se mais problemática. O tratamento crítico mais organizado que a novella teve no Cinquecento, embora a julgasse em moldes aristotélicos, não procurou reabilitá-la como forma artística ${ }^{36}$. Por retratar a experiência diária de pessoas comuns em tons de ridículo, a novella não poderia recorrer à linguagem elevada da tragédia ou da epopéia, o que dificultava sua classificação como poesia. Na França seiscentista a prosa de ficção que retratava o quotidiano careceria igualmente de apreço crítico, não merecendo grande atenção dos autores que reformularam o projeto literário de seu país, como Du Bellay e Ronsard ${ }^{37}$. No século seguinte ela ganharia finalmente a atenção dos críticos, mas o tratamento dado a gêneros como o roman comique e a nouvelle (mais fincados na realidade do que as estórias romanescas) não procurava reconciliá-los com a poética clássica: eles eram vistos como formas arrivistas, estranhas à província do neoclassicismo. Essa atitude se transplantou para a Inglaterra seiscentista, onde o debate sobre a prosa de ficção, carente de teorização nativa, era ainda dominado pelo pensamento francês.

Ora, na França a desavença entre os círculos letrados e a prosa de ficção ia além da falta de precedentes antigos. Entravam em jogo questões de moralidade e verossimilhança. Durante algum tempo a estória romanesca conseguiu atender a esses requisitos neoclássicos com seu retrato idealizado de episódios históricos e figuras reais, como Ciro, o Grande ${ }^{38}$. Seus

\footnotetext{
${ }^{35}$ Cf. Zuber e Cuénin, Le Classicisme, p. 151; Salzman, “Theories of prose fiction in England: 1558-1700”, In Glyn P. Norton (ed.). The Renaissance, pp. 301-302; e Sutherland, English Literature of the Late Seventeenth Century, pp. 202-3.

${ }^{36}$ Trata-se das Lezione sopra il comporre delle novelle (1574), de Francesco Bonciani , texto que até o século XVIII só foi lido em forma manuscrita por círculos restritos. Glyn P. Norton e Marga Cottino-Jones, “Theories of prose fiction and poetics in Italy: novella and romanzo (1525-1596)”. In Glyn P. Norton (ed.). The Renaissance, pp. 322-335.

37 Glyn P. Norton, “Theories of prose fiction in sixteenth-century France”. In Glyn P. Norton (ed.). The Renaissance, pp. 305-313.

${ }^{38}$ G. J. Mallinson, “Seventeenth-century theories of the novel in France”. In Glyn P. Norton (ed.). The Renaissance, pp. 315-6.
} 
defensores invocavam a distinção entre vrai (verdadeiro) e réel (real): o verdadeiro (donde verossímil) se baseava numa recriação moralmente correta da história, ao passo que o real deixava de lado a censura prévia e apresentava o mundo em forma bruta, sendo intrinsecamente imoral $^{39}$. O roman, com seus heróis e heroínas modelares (porém históricos), conseguia ser a um só tempo verossímil e edificante. Mas essa solução não perdurou. O artificialismo do mundo romanesco constituía um obstáculo para a validade das lições morais: como esperar que um bon vivant se emendasse com exemplos tão afastados da vida comum? A saída seria retificar o verdadeiro sem incorrer na indecência do real. Insinua-se aqui o dilema característico da prosa de ficção francesa dessa época: os autores oscilavam entre um idealismo tido por mentiroso e um realismo tido por imoral ${ }^{40}$.

Uma solução para o dilema foi oferecida pelo roman comique, forma que almejava os mesmos fins morais que o grand roman sem omitir a realidade quotidiana. O Roman Bourgeois (1666), de Furetière, será “bourgeois” a um só tempo por evitar a ficção aristocrática e pôr na ribalta o mundo prosaico da burguesia. "Cumpre para isso que a natureza das histórias e os caracteres das pessoas se apliquem de tal modo a nossos costumes que creiamos reconhecer neles a gente que vemos todos os dias.”41 Pintura da realidade? Sim, mas com uma demão de escárnio. A esse respeito, Ronald Paulson observou:

O escritor do período que desejasse expressar a experiência comum da vida quotidiana, como oposta ao alto mundo aristocrático do romanesco ou ao mundo religioso do combate espiritual, tinha de recorrer, como modelos, à comédia ou à sátira. Ele não encontraria tal tipo de relato nos gêneros trágico, épico ou romanesco, em que isso romperia as regras do decoro, bem como as premissas do gênero; desde que Aristóteles fez a distinção de que a comédia lidava com uma imitação do homem como inferior ao que é, e a tragédia do homem como superior ao que é,

\footnotetext{
${ }^{39}$ English Showalter, “Prose fiction: France”. In Nisbet e Rawson (ed.). The Eighteenth Century, p. 219.

${ }^{40}$ Pomeau e Ehrard, De Fénelon à Voltaire, p. 176. O principal estudo a esse respeito é o de Georges May, Le Dilemme du roman au XVIII siècle, ao qual infelizmente ainda não tive acesso.

41 “Il faut pour cela que la nature des histoires et les caractères des personnes soient tellement appliqués à nos moeurs, que nous croyons y reconnaître les gens que nous voyons tous les jours.” Furetière, “Avertissement” de Le Roman Bourgeois, p. 24.
} 
poucos tentaram violá-la. O real era o baixo e o baixo era o cômico. ${ }^{42}$

O retrato da vida quotidiana, visto como frívolo ou imoral, era justificado pelo argumento típico dos comediógrafos: a exibição de vícios não seria degradante, desde que feita com finalidades reformadoras. Os personagens desse tipo de narrativa - cujo pilar é a Histoire Comique de Francion (1623), de Sorel — costumavam caracterizar-se por um hábito aviltante que caberia à sátira condenar. O enfoque era portanto oposto ao do roman, cujos protagonistas eram espelhos de virtude. No Roman Comique (1651) de Scarron vemos a confluência desses dois mundos: os personagens de perfil romanesco, como Mademoiselle de L’Étoile e Le Destin, são retratados com simpatia pelo narrador, ao passo que figuras mais realistas, como Ragotin e La Rancune, são flagelados a cada página. Esse é um bom método para recomendar a virtude e destratar o vício, mas ele impunha duras limitações ao realismo, sobretudo em matéria de caracterização. Isso fica bastante visível num romance como Le Diable Boiteux (1707), de Le Sage, em que o diabo manco Asmodeu levanta os telhados de Madri para que Dom Cleofas possa testemunhar as intrigas domésticas de seus compatriotas. Essa visão instantânea dos madrilenses — um "quadro dos costumes do século"43 — dificulta em muito o desenvolvimento psicológico. Os personagens tornam-se necessariamente unidimensionais. Nos termos de Paulson, são personagens “legalistas” (definindo-se por uma dada ação), como opostos aos personagens “orgânicos” do romance (que se desenvolvem no tempo e recebem um tratamento mais empático $)^{44}$. O que o roman comique fazia, na prática, era submeter a realidade a um outro tipo de filtro, novo mas igualmente limitador.

É na tentativa de evitar tanto o idealismo do grand roman como o realismo insatisfatório do roman comique que uma outra forma surge em meados do século: a nouvelle.

\footnotetext{
42 "The writer of the period who wished to express the ordinary experience of day-to-day life, as opposed to the high aristocratic world of romance or the religious world of spiritual combat, had to go for his models to comedy or satire. He could not find such an account in the tragic, epic, or romantic genres, where it would have broken the rules of decorum as well as the assumptions of the genre; once Aristotle had made the distinction that comedy dealt with an imitation of man as less than he is and tragedy with man as more than he is, few attempted to violate it. The real was the low and the low was the comic." Paulson, Satire and the novel in eighteenthcentury England, p. 14.

${ }^{43}$ Le Sage, Le Diable Boiteux, p. 272. O livro é uma adaptação de El Diablo Cojuelo, de Velez de Guevara (1641).

${ }^{44}$ Paulson, op. cit., p. 3.
} 
Em suas Nouvelles françoises (1656), Segrais professará a intenção de “expor as imagens das coisas como ordinariamente as vemos ocorrer"45. A obra-prima do gênero - A Princesa de Clèves (1678), de Madame de Lafayette — , apesar do ambiente palaciano, se destacará pela verossimilhança e pela complexidade psicológica, distando em muito do universo exaltado do roman. O problema é que, com a tentativa da nouvelle de emular mais fielmente a história, a censura romanesca sai de cena e materiais vistos anteriormente como perniciosos voltam ao escopo dos escritores. Mesmo a relativamente correta Princesa de Clèves se tornou objeto de acalorada discussão crítica, prenunciando a grande polêmica moralista da década de 1730 .

Todos os três gêneros acima ganharam circulação na Inglaterra em traduções ou imitações, promovendo entre os ingleses o mesmo debate que já fremia na França. Os pecados da inverossimilhança ou da imoralidade seriam apontados com igual afinco e iguais furores. $\mathrm{O}$ grand roman, como vimos, perdeu o apreço dos autores pouco depois da Restauração, mas manteve-se caro aos leitores, que com o tempo seriam censurados em razão de seu gosto pelo maravilhoso. O roman comique não exerceria grande influência na Inglaterra até que autores sofisticados como Fielding e Smollett aproveitassem sua mistura entre sátira e realismo. Essa forma, que com sua ótica intelectualista era mais condizente com as inclinações augustanas, pecava porém por sua estrutura episódica, ofensiva ao requisito neoclássico de unidade ${ }^{46}$. A nouvelle, com seu realismo sem decoro, seria a mais ofensiva das formas: muito imitada na Inglaterra em fins do século XVII, ela seria alvo da maioria das acusações de imoralidade, já que seus temas usuais eram intrigas de amor e galanteria, dificilmente justificadas pelas breves sabatinas morais ao final. Caracteristicamente, uma figura comum na literatura inglesa do século XVIII seria a jovem desencaminhada por esse tipo de leitura ${ }^{47}$. Ademais, a associação da prosa de ficção com o escândalo, a calúnia, a corrupção, a alienação ou a mera irrelevância só se reforçava com a corrência de gêneros como as histórias secretas, as memórias, as falsas cartas de amor, as biografias de criminosos e os relatos de viagens a terras fantásticas. Uma prática comum a várias dessas formas era a pretensão à absoluta veracidade,

\footnotetext{
45 “donner les images des choses comme d’ordinaire nous les voyons arriver”. Citado por English Showalter, op. cit., p. 210.

${ }^{46}$ Segundo Aristóteles: “Das fábulas e ações simples, as episódicas são as mais fracas”, Poética, IX, p. 29.

47 Alguns exemplos são Manley, The New Atalantis, I, p. 83; Smollett, Roderick Random, XXII, p. 119; Mackenzie, The Man of Feeling, XXVIII, p. 42; e Sheridan, The Rivals, I, ii.
} 
ofensiva à separação aristotélica entre história e poesia. (Sobre isso terei mais a dizer na Parte II.) E havia um último problema, que não se configurara de todo nos três gêneros franceses: a mistura de estilos. Horácio condenara expressamente o tratamento sério de temas baixos ${ }^{48}$, e era isso o que vinha caracterizando boa parte da prosa de ficção na virada do século XVII. Some-se esse último pecado aos anteriores, e a conclusão será esta: num ambiente em que a boa literatura era julgada (ainda que liberalmente) segundo critérios neoclássicos, a prosa de ficção só poderia ser uma forma marginal, desdenhada por literatos ciosos de sua reputação.

O último problema que mencionei (a mistura de estilos) merece uma consideração final. É interessante notar que o poema herói-cômico — forma de MacFlecknoe e The Rape of the Lock, obras centrais da poesia augustana - cometia igualmente esse pecado. Haveria algo que tornasse a violação especialmente perniciosa no caso da prosa de ficção realista? Sem dúvida. Como já vimos, até essa época era incomum que as classes inferiores figurassem na literatura sem um viés depreciativo. Algumas exceções inglesas eram as obras de Thomas Deloney, que procuravam exaltar os artesãos e cujo principal personagem, “cujas terras são seus teares"49, desdenha um título de fidalguia que lhe oferece Henrique VIII; e The Shoemaker's Holiday (1599), de Thomas Dekker, comédia cujo protagonista, filho de um sapateiro, trazia como divisa "Não sou nenhum príncipe, mas nasci principescamente” ${ }^{\text {. Em }}$ ambos os casos está implícito um conceito de respeitabilidade independente do sangue ou do status nobiliárquico. Isso também transparece em tragédias domésticas elisabetanas como $A$ Woman Killed with Kindness (1603), de Thomas Heywood, e a anônima Arden of Faversham (1587-92), que se encerra com uma justificação de sua crueza: "Porquanto a simples verdade é assaz graciosa / E dispensa outros toques de lustrosa matéria” ${ }^{51}$. O que vemos neste caso é o vínculo entre a vida diária e a seriedade trágica (o assunto de Auerbach) e a equiparação

\footnotetext{
48 “A um tema cômico repugna ser desenvolvido em versos trágicos.” Arte Poética, p. 57.

${ }^{49}$ (...) “whose lands are his looms”. Jack of Newbury, 2. In Paul Salzman (ed.), An Anthology of Elizabethan Prose Fiction, p. 339.

50 “Prince am I none, yet am I princely born.” The Shoemaker's Holiday, III, iv. In Dunn (ed.), Eight Famous Elizabethan Plays, p. 94. A peça de Dekker foi baseada em The Gentle Craft, de Deloney. Simon Eyre fora um negociante de tecidos que se elegera prefeito de Londres em 1419 (ou 1446).

51 "For simple truth is gracious enough, / And needs no other points of glozing stuff." Arden of Faversham, Epílogo, p. 103.
} 
implícita dos problemas do sangue plebeu aos do sangue azul. A mistura de estilos, como já podemos notar nesses exemplos remotos, não era um simples dilema estético. Quando envolvesse a elevação do homem comum a objeto de tratamento sério, ela era socialmente perniciosa. E se tornaria mais freqüente com o passar do tempo. Seu ápice seria a Clarissa (1747-8) de Richardson, mas a tendência já se fazia visível em textos como The History of the Nun (1689), de Aphra Behn, e a coletânea Delightful Novels Exemplified in Eight Choice and Elegant Histories (1686). No primeiro terço do século XVIII ela teria em Daniel Defoe um destacado cultor, em cujas obras o marinheiro, o soldado raso, a ladra e o mercador assumiriam o centro do palco, com dignidade não inferior à de um duque ou marquês. $\mathrm{O}$ próximo capítulo tratará mais extensamente das implicações socioeconômicas do novo gênero, tomando como ponto de partida a distinção entre romance e romanesco. 


\subsection{Romance e sociedade}

Um dos poucos augustanos a deixar atrás de si um espécime bem acabado de prosa de ficção foi o dramaturgo William Congreve, que antes de enveredar pelo teatro compôs Incognita; Or, Love and Duty Reconciled; A Novel, publicando-a sob pseudônimo em 1692. Semelhante em muitos sentidos a uma comédia da Restauração em forma narrativa, a obra é mais conhecida hoje por seu "Prefácio ao leitor”, em que Congreve esboça uma distinção precoce entre novel e romance. Sua idéia de novel é ainda influenciada pela nouvelle francesa, mas os termos do prefácio são sugestivos:

Estórias romanescas [romances] consistem geralmente nos amores constantes e coragens invencíveis de heróis, heroínas, reis e rainhas, mortais de primeira grandeza e assim por diante. Nelas a linguagem exaltada, incidentes milagrosos e feitos impossíveis deslumbram e surpreendem o leitor em irrefletido deleite (...) Romances [novels] são de natureza mais familiar; aproximam-se mais de nós, representando intrigas na prática. Deleitam-nos com incidentes e eventos singulares, mas não a ponto de serem totalmente incomuns ou inauditos eventos de tal natureza que, por não distarem do crível, tornam o prazer igualmente mais próximo. $^{52}$

Essa tentativa de definição dos termos, que não sanará a ambigüidade persistente no século XVIII, prefigura pronunciamentos futuros como o de Horace Walpole ${ }^{53}$ e especialmente o de Clara Reeve, em The Progress of Romance (1785):

\footnotetext{
52 "Romances are generally composed of the constant loves and invincible courages of heroes, heroines, kings and queens, mortals of the first rank, and so forth; where lofty language, miraculous contingencies and impossible performances elevate and surprise the reader into a giddy delight (...) Novels are of a more familiar nature; come near us, and represent to us intrigues in practice; delight us with accidents and odd events, but not such as are wholly unusual or unprecedented - such which, not being so distant from our belief, bring also the pleasure nearer us." Incognita, "Preface to the reader". In Salzman (ed.), An Anthology of Seventeenth-Century Fiction, p. 474.

${ }^{53}$ Cf. o prefácio à segunda edição de The Castle of Otranto (1764).
} 
O romance é um retrato da vida real e seus modos, e dos tempos em que ele é escrito. O romanesco, em linguagem altiva e elevada, descreve o que nunca ocorreu nem provavelmente ocorrerá. O romance faz um relato familiar daquelas coisas que transcorrem todos os dias diante de nossos olhos, que podem ocorrer a nosso amigo ou a nós mesmos; e sua perfeição está em representar cada cena de modo tão simples e natural, e fazer com que elas pareçam tão prováveis, que nos deixemos persuadir (ao menos enquanto lemos) de que tudo é real, a ponto de sermos afetados pelas alegrias ou angústias das pessoas na estória, qual fossem as nossas próprias. $^{54}$

A prática de definir o romance por oposição ao romanesco tornou mais visível a transição que vinha sofrendo a prosa de ficção inglesa nos tempos de Congreve. Para isso contribuiu a estabilização taxonômica em fins do século XVIII, facilitada pela arte assumidamente romanesca dos escritores góticos. Na França, por exemplo, o termo roman, após um período de rejeição ${ }^{55}$, voltaria a vigorar com um sentido absolutamente diverso do seiscentista, e como resultado a mudança genérica seria menos visível, embora igualmente real. Em The Progress of Romance a distinção entre os gêneros já é exposta com suficiente nitidez, e a fórmula de Clara Reeve se tornaria canônica, ressurgindo em versões mais recentes. Lennard Davis, por exemplo, enumera nove diferenças fundamentais entre romanesco e romance, como as de ambientação antiga ou recente, tratamento idealizado ou realista e profissão de ficção ou veracidade. Especialmente interessante é a quarta distinção de Davis: "O romanesco retrata a vida da aristocracia e destina-se a um leitor de alta classe; o romance tende a ser mais classe média em escopo e volta-se a um público menos

\footnotetext{
54 "The Novel is a picture of real life and manners, and of the times in which it is written. The Romance in lofty and elevated language, describes what never happened nor is likely to happen. The Novel gives a familiar relation of such things, as pass every day before our eyes, such as may happen to our friend, or to ourselves; and the perfection of it, is to represent every scene, in so easy and natural a manner, and to make them appear so probable, as to deceive us into a persuasion (at least while we are reading) that all is real, until we are affected by the joys or distresses, of the persons in the story, as if they were our own." Citado por Paulson, op. cit., p. 12.

${ }^{55}$ De 900 narrativas em prosa publicadas na França entre 1700 e 1750, somente cerca de meia dúzia assumiram a classificação como roman. Pomeau e Ehrard, op. cit., p. 176.
} 


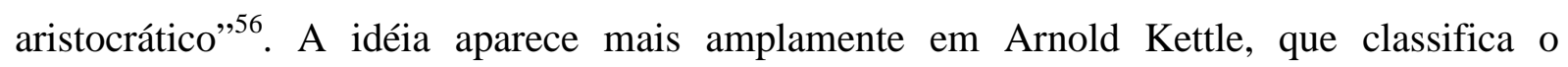
romanesco (excluída sua variedade em verso) como

a literatura não realista e aristocrática do feudalismo. Ela era não realista no sentido de que seu propósito subjacente não era ajudar as pessoas a lidar de maneira positiva com o ofício de viver, e sim transportá-las a um mundo diferente, idealizado, melhor que o delas. Era aristocrática porque as atitudes que expressava e recomendava eram precisamente as atitudes que a classe governante desejava incentivar (muitas vezes inconscientemente, sem dúvida) para que sua posição privilegiada pudesse ser perpetuada. ${ }^{57}$

Já o romance, para Kettle, é o gênero em que a burguesia replica ao universo romanesco da aristocracia:

Para o burguês, como vimos, a sociedade feudal não era satisfatória, mas frustrante. E ele não sentia impulsos de defender essa sociedade, e tampouco simpatia por uma literatura destinada a recomendar seus valores e ocultar suas limitações. Pelo contrário, suas necessidades e instintos o exortavam a expor e solapar as normas e convenções feudais. Diversamente da classe governante feudal, ele não se sentia imediatamente ameaçado por revelações da verdade sobre o mundo, e por isso não tinha medo do realismo. ${ }^{58}$

\footnotetext{
${ }^{56} \mathrm{O}$ estudo de Davis procura a origem do romance no discurso a que ele chamou news/novel — ou "narrativa em prosa impressa" (p. 44) —, cujo desmembramento faz surgir de um lado a história e o jornalismo, e de outro o romance. A tese é de considerável interesse, mas parece-me demasiado restritiva. Eis o original: "The romance depicts the life of the aristocracy and it designed for an upper-class reader; the novel tends to be more middle class in scope and is geared to a slightly less aristocratic readership.” Davis, Factual Fictions: The Origins of the English Novel, p. 40.

57 "Romance was the non-realistic, aristocratic literature of feudalism. It was non-realistic in the sense that its underlying purpose was not to help people cope in a positive way with the business of living but to transport them to a world different, idealized, nicer than their own. It was aristocratic because the attitudes it expressed and recommended were precisely the attitudes the ruling class wished (no doubt usually unconsciously) to encourage in order that their privileged position might be perpetuated.” Kettle, An Introduction to the English Novel, V. 1, p. 31.

58 "To the bourgeois man, as we have seen, feudal society was not satisfying but frustrating. And he felt no impulse to defend that society and no sympathy with a literature designed to recommend its values and conceal its limitations. On the contrary his every need and instinct urged him to expose and undermine feudal standards and sanctities. Unlike the feudal ruling class he did not feel himself immediately threatened by revelations of the truth about the world and so he was not afraid of realism.” Kettle, op. cit., p. 38.
} 
Aos dois modelos de prosa de ficção, portanto, correspondem dois universos distintos de produção e consumo da literatura. A oposição usual entre romanesco e romance (haja ou não descendência direta entre ambos) traz em seu bojo a oposição entre duas realidades sociais distintas, de modo que a transição dos gêneros literários vincula-se necessariamente a transformações socioeconômicas. É essa a premissa básica do já clássico A Ascensão do Romance, de Ian Watt, publicado originalmente em 1957. O propósito de Watt foi diferenciar o romance das formas anteriores de ficção em prosa - como o romanesco e a picaresca - e apresentar as razões para que tais diferenças se produzissem na Inglaterra do século XVIII. O que distinguiria a obra de autores como Defoe e Richardson era

a premissa, ou convenção básica, de que o romance constitui um relato completo e autêntico da experiência humana e, portanto, tem a obrigação de fornecer ao leitor detalhes da história como a individualidade dos agentes envolvidos, os particulares das épocas e locais de suas ações detalhes que são apresentados através de um emprego da linguagem muito mais referencial do que é comum em outras formas literárias. ${ }^{59}$

A expressão narrativa dessa premissa é o “realismo formal”, caracterizado pela rejeição dos enredos tradicionais, pela apresentação de pessoas e circunstâncias específicas, pela individualização dos personagens, por maior precisão no tratamento de tempo e espaço, e pela linguagem referencial. Cada uma dessas características formais vinculava-se a tendências filosóficas e processos sociais concomitantes. Entre as primeiras, Watt enfatiza sobretudo as investigações de Locke sobre o conhecimento humano, que despertaram grande atenção para problemas ligados ao individualismo. Entre as últimas, ele destaca o aumento da alfabetização e a conseqüente consolidação de um novo público leitor; a progressiva importância de capitalistas e comerciantes; e a secularização da sociedade. ${ }^{60} \mathrm{O}$ resultado é um elo simbiótico entre a ascensão do romance e a mentalidade de classe média, entre forma literária e processo social. A influência dessa tese deu grande alento aos estudos historicistas da gênese do

\footnotetext{
${ }^{59}$ Watt, A Ascensão do Romance, p. 31.

${ }^{60}$ Idem, capítulos 2 e 3.
} 
romance, e desde então tornou-se difícil escrever sobre o assunto sem mencionar o precedente de Watt. O conceito de realismo formal seria objeto de críticas e reformulações por parte de teóricos posteriores, mas a relação entre literatura e sociedade manteve-se uma premissa comum desse campo. Isso se evidencia em dois estudos recentes de grande fôlego, que partem de Watt mas reformulam seu argumento: The Origins of the English Novel-1660-1740 (1988), de Michael McKeon, e Before Novels: The Cultural Contexts of Eighteenth-Century Fiction (1990), de J. Paul Hunter. São dois estudos fundamentais para meu exame de Gulliver, e merecem seções à parte.

\subsubsection{McKeon}

McKeon critica em Watt a diferenciação categórica entre romanesco e romance, já que o romance do século XVIII preservava elementos romanescos e traços da ideologia aristocrática. Ele também aponta a falta de evidências de que o espírito de classe média e o individualismo moderno surgiram na época em que, segundo Watt, o romance ascendeu. O objetivo de McKeon é justificar a complexidade do gênero em sua fase de formação e reformular o vínculo entre a ascensão do romance e a da classe média. O ponto de partida é a idéia de que o romance, como gênero, constitui uma abstração simples, "uma categoria enganosamente monolítica que encerra um complexo processo histórico"61 — categoria que só pode ser formulada depois de uma longa preexistência. É essa preexistência que interessa a McKeon. Ele retrocede da rivalidade crucial entre Richardson e Fielding (momento em que o romance atinge sua identidade canônica) e se concentra no período entre 1600 e 1740.

Essa é uma época marcada pela instabilidade em categorias genéricas e sociais — pela incerteza sobre como dizer a verdade nas narrativas e estimar a virtude dos indivíduos. Até o fim do século XVI, verdade e virtude eram determinadas univocamente pela idéia de linhagem, que pressupunha a veracidade dos textos por sua filiação à tradição e a virtude dos indivíduos por sua ancestralidade genealógica. No século XVII, o prestígio da linhagem foi abalado nos dois campos. A nova filosofia havia desacreditado as antigas autoridades, de modo que invocá-las não era visto como garantia de verdade. E com a dissolução do conceito de honra e a concessão abusiva de títulos nobiliárquicos sob os Stuarts, o status não era visto

\footnotetext{
${ }^{61}$ McKeon, The Origins of the English Novel, p. 20.
} 
como garantia de virtude. Deixou por conseguinte de haver um princípio que atendesse simultaneamente a problemas epistemológicos e sociais, e eles acabaram se cindindo em campos distintos, qual fossem questões sem relação mútua.

A instabilidade das categorias genéricas registra uma crise epistemológica, uma acentuada transição cultural nas atitudes sobre como dizer a verdade na narrativa. Por conveniência, chamarei ao conjunto de problemas associados com essa crise epistemológica "questões de verdade”. A instabilidade das categorias sociais registra uma crise cultural nas atitudes sobre como a ordem social externa se relaciona ao estado moral interno de seus membros. Por conveniência, chamarei ao conjunto de problemas associados com esta crise social e ética “questões de virtude". ${ }^{6}$

As origens do romance, para McKeon, consistem "no estabelecimento de uma forma suficiente para a investigação simultânea de problemas epistemológicos e sociais análogos”63. Em outras palavras, o romance vem resgatar o vínculo entre questões de verdade e questões de virtude, o qual se desfizera com a obsolescência da idéia de linhagem. No período 16001740 esses dois conjuntos de questões foram tratados a princípio como pertencentes a universos estanques; com o tempo e com muita experimentação os escritores finalmente se deram conta da analogia existente entre os dois universos.

Inicialmente, os conflitos paralelos decorrentes da crise epistemológica e da crise social geram soluções autônomas para as questões de verdade e de virtude. No primeiro caso, surgem novos modos de dizer a verdade na narrativa; no segundo, novos critérios para avaliar a virtude íntima dos indivíduos. Tanto em um como em outro caso, a solução proposta não é única. O que ocorre é uma dupla negação: a postura original A é negada por uma postura B, e esta, por sua vez, é negada por uma postura C, que retoma ligeiramente os valores de $\mathrm{A}^{64}$.

\footnotetext{
62 "The instability of generic categories registers an epistemological crisis, a major cultural transition in attitudes toward how to tell the truth in narrative. For convenience, I will call the set of problems associated with this epistemological crisis 'questions of truth.' The instability of social categories registers a cultural crisis in attitudes toward how the external social order is related to the internal, moral state of its members. For convenience, I will call the set of problems associated with this social and ethical crisis 'questions of virtue.”' Idem, p. 20.

${ }^{63}$ Ibidem, p. 410.

${ }^{64} \mathrm{O}$ esquema ABC não está em McKeon. Emprego-o para facilitar a explicação.
} 
Em questões de verdade, a postura A é o que McKeon chama de "idealismo romanesco", que afirma a veracidade dos textos pelo recurso à tradição e às antigas autoridades. A postura B, denominada “empirismo simplório”, refuta os princípios do idealismo romanesco, denunciando as invenções da tradição e preferindo emular a história. Surgem daí as afirmações de que narrativas ficcionais são a exposição de fatos absolutamente reais - um meio de convencer os leitores de que a obra diz a verdade. A postura C, chamada de “ceticismo extremo", ataca a falsa historicidade dos empiristas e defende a busca não de simulacros históricos, e sim da verossimilhança. As narrativas podem assumir-se ficcionais e continuar dizendo a verdade, desde que tratem de questões ligadas à realidade. Ao adotar uma crítica menos entusiástica, o ceticismo extremo fatalmente retoma algumas das características do idealismo romanesco, sem deixar contudo de refutá-lo. Isso o situa a meio caminho entre as duas outras posturas.

Em questões de virtude, a postura A é o que McKeon chama de “ideologia aristocrática”, que defende a virtude de nascença e a respeitabilidade como acessório do status. A postura B, denominada “ideologia progressista”, refuta a ideologia aristocrática em prol da meritocracia, sustentando que a virtude não é apanágio do berço e deve ser medida de acordo com o sucesso pessoal do indivíduo. Ocorre aqui o avanço da classe (respeitabilidade socioeconômica) sobre o terreno do status (respeitabilidade de nascimento, ou honorífica). A postura C, chamada de “ideologia conservadora”, acusa a ideologia progressista de simplesmente substituir o nascimento pelo dinheiro, a medida mais comum do sucesso - e por conseguinte do "mérito" - individual. Para os conservadores, o status costuma, sim, proporcionar virtude, não pelo berço nobre, e sim pela educação esmerada que ele proporciona a seus membros — educação de que os novos-ricos careciam. Ao adotar uma crítica menos entusiástica, a ideologia conservadora fatalmente retoma algumas das características da ideologia aristocrática, sem deixar contudo de refutá-la. Isso a situa a meio caminho entre as duas outras posturas.

Essa breve exposição basta para sugerir a simetria existente entre questões de verdade e questões de virtude. Um diagrama pode deixá-la mais clara. 


\section{Questões de Verdade}

A Idealismo romanesco

B Empirismo simplório

C Ceticismo extremo

\section{Questões de Virtude}

Ideologia aristocrática

Ideologia progressista

Ideologia conservadora

As duas colunas se espelham: a filiação ao empirismo simplório tende a acompanhar a filiação à ideologia progressista, e o mesmo vale para as outras posturas. "No contexto da primitiva narrativa moderna, escolhas epistemológicas têm relevância ideológica, e uma dada explicação do significado da mobilidade social provavelmente implicará um certo procedimento e compromisso epistemológico.”65 Com o tempo, os escritores se deram conta disso e perceberam que dificuldades relativas a questões de verdade podiam ser iluminadas por reflexões sobre questões de virtude. A investigação simultânea desses dois campos passou a ser empreendida tanto pela postura B como pela postura C. O romance assume sua identidade "quando a confluência passa a ser feita com tal mestria que o conflito entre empirismo simplório e ceticismo extremo, entre as ideologias progressista e conservadora, pode ser incorporado numa controvérsia pública entre escritores que empregam consabidamente métodos antitéticos para escrever o que se reconhece ainda assim como a

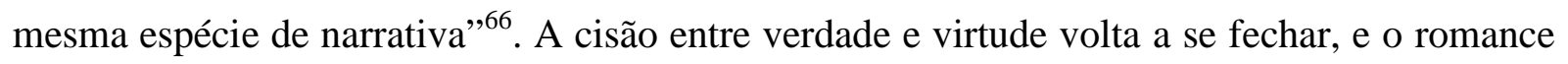
é seu elemento mediador.

É assim que McKeon procura resolver os problemas que apontara em Watt. A permanência de elementos romanescos no século XVIII deve-se ao fato de que o ceticismo extremo retoma certas características do idealismo romanesco, como a aceitação da ficcionalidade. E a analogia entre problemas epistemológicos e socioéticos resgata e sofistica a relação entre a ascensão do romance e a da classe média, pois esta é igualmente uma abstração simples "cujas origens modernas mascaram uma considerável preexistência"67. O espírito de classe média está por trás da crítica à tradição empreendida pela postura B, mas

\footnotetext{
${ }^{65}$ Ibidem, p. 266.

66 “ $(. .$.$) when the conflation comes to be made with such mastery that the conflitct between naive empiricism and$ extreme skepticism, between progressive and conservative ideologies, can be embodied in a public controversy between writers who are understood to employ antithetical methods of writing what is nonetheless recognized as the same species of narrative.” Ibidem, p. 266.

${ }^{67}$ Ibidem, p. 22.
} 
com o advento da postura C a ascensão do romance passa a incluir também autores conservadores vinculados à aristocracia e amiúde avessos a esse espírito.

\subsubsection{Hunter}

Ao descartar o realismo formal e sugerir como denominador comum do romance a analogia entre problemas epistemológicos e socioéticos, McKeon estabelece a continuidade entre romanesco e romance e alarga o leque de obras que participaram das origens do gênero. J. Paul Hunter será ainda mais eclético na variedade de obras estudadas, mas divergirá de McKeon quanto à genealogia comum de romance e romanesco. "Se o romance precisa ser diferenciado do romanesco, e se surgiu para proporcionar, na prática, uma alternativa ao romanesco, não se segue necessariamente que ele descendeu do romanesco.”68 Os propósitos de Hunter, expostos extensamente na página xix de seu livro, incluem oferecer uma descrição operacional do romance; reafirmar sua condição de gênero novo; incluir em seu processo de formação autores não canônicos e até mesmo obras não ficcionais; evitar a idéia de romance fundador" ${ }^{69}$; e "mostrar como os leitores conquistam o poder de criar textos comunicando, embora não necessariamente de modo consciente ou direto, suas necessidades e desejos àqueles em condições de produzir livros" ${ }^{\text {70 }}$. Com tudo isso ele pretende situar o romance emergente no contexto mais amplo da história cultural, avaliando a influência, em sua formação, de jornais, guias de conduta, materiais didáticos, elementos da cultura oral e outras fontes.

Para definir aquilo cujas origens está buscando, Hunter elabora uma ampla descrição do romance, retomando elementos do realismo formal de Watt mas complementando-os com uma série de outras características. Estas se dividem em dois grupos: as comumente aceitas pela crítica e as mais polêmicas ou menos comentadas. As primeiras são: contemporaneidade; credibilidade e probabilidade; familiaridade (existência quotidiana e personagens comuns); rejeição de enredos tradicionais; linguagem liberta da tradição; individualismo e

\footnotetext{
68 "If the novel needs to be distinguished from romance, and if the novel came to provide, in effect, an alternative to romance, it does not necessarily follow that the novel descended from romance.” J. Paul Hunter, Before Novels: The Cultural Contexts of Eighteenth-Century Fiction, p. 28.

${ }^{69}$ Nisso ele coincide com McKeon. Ver The Origins of the English Novel, p. 267.

70 "show how readers gain the power to create texts by communicating, though not necessarily consciously or directly, their needs and desires to those in a position to make books”. Hunter, op. cit., p. xix.
} 
subjetividade; empatia e vicariedade; coerência e unidade de concepção; inclusividade, digressividade e fragmentação; e autoconsciência quanto à inovação e à novidade. As características do último grupo, que a crítica costuma evitar por serem comprometedoras para a visão estável do gênero, mas que aparecem nele com freqüência, são o maravilhoso; o tabu; a vida privada; o teor individualista; a mediação com o público; a epistemologia; as estórias internas; as interpolações discursivas; e o tom didático ${ }^{71}$. Para Hunter, essa descrição operacional, que não procura ser uma definição essencialista do gênero, deve ser levada em conta em qualquer teoria de origens que pretenda fazer jus à complexidade do romance em seus primórdios. O problema que se impõe, então, é o seguinte: de que maneira essas características ganharam forma e convergiram num novo gênero literário significativo e duradouro? Hunter procura retratar esse processo recriando a consciência cultural dos leitores da época e explorando outras espécies de escritos em que tais características vinham se formando gradualmente, em resposta aos interesses e desejos do novo público — escritos que constituem fontes negligenciadas da origem do romance.

Na linha de Ian Watt, Hunter reapresenta com cifras atualizadas o fenômeno do crescimento do público leitor nos séculos XVII e XVIII. Segundo estimativas recentes, 25\% dos homens adultos na Inglaterra sabiam ler em 1600; e entre 70\% e 80\% em 1800. Em 1675 entre dois terços e três quartos da evolução já haviam ocorrido. Uma vez que as altas camadas já eram alfabetizadas, esses novos leitores encontravam-se em maioria na classe média ${ }^{72}$, e vinham proporcionar uma audiência para formas literárias com pouca penetração nos corredores da elite. Os diferentes desejos desse público - e por “desejo” Hunter entende um

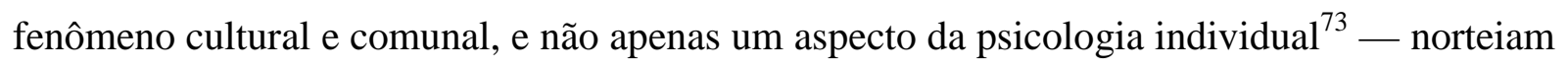
os rumos da escrita. Autores com inclinações inovadoras se empenharam em sondar as expectativas dos leitores e deixaram que elas influíssem em sua produção literária. Boa parte dos novos leitores, por exemplo, eram jovens provindos do campo para mudar de vida após gerações de existência rural, ou filhos alfabetizados de pais analfabetos. Entre os fatores que determinavam seus desejos estavam a perda dos elos afetivos da vida do campo, o

\footnotetext{
${ }^{71}$ Muitas dessas características pediriam elucidações inevitavelmente longas. Sugiro ao leitor interessado que as consulte na fonte; ver p. 30 e seguintes.

${ }^{72}$ Idem, p. 66.

${ }^{73}$ Idem, p. xix.
} 
desaparecimento dos contos de fadas e o rompimento com o passado tradicional ${ }^{74}$. Em sua busca por desvendar o mundo das pessoas adultas e saber como agir frente às expectativas sociais, eles recorriam a uma variedade de formas literárias de conteúdo orientador — guias de conduta, retóricas didáticas, livros de providência e finalmente romances ${ }^{75}$. Em outra parte, Hunter observa:

Muitos leitores de romances eram decerto jovens; a maioria dos romances era sobre jovens prestes a tomar decisões importantes na vida sobre a carreira, o amor ou ambos, e parecia voltada a leitores em situações similares. (...) [O]s romances se tornaram, para dezenas de milhares de rapazes e moças na Inglaterra setecentista, guias para muitas decisões práticas na vida, equivalentes das estórias familiares e da tradição oral em gerações anteriores, e de filmes e livros de auto-ajuda em gerações posteriores. ${ }^{76}$

Como resultado das novas tendências, Hunter identifica duas ondas de inovação literária, em 1690 e em 1740. “O movimento da virada do século não legou muito coisa de mérito duradouro, embora a maioria das obras literárias celebradas do início do século XVIII tenha sido escrita em reação a ele.”77 O contra-ataque augustano e a falta de concepção, por parte dos inovadores, de como devia ser uma nova literatura, minimizaram os efeitos dessa onda. A segunda onda, mais decisiva, é a que inclui Fielding e Richardson. Entre ambas, surgiram quatro tipos de textos em que as características do romance se fermentariam: textos jornalísticos, com sua preocupação com eventos correntes; textos didáticos, com sua ênfase no aconselhamento; escritos privados e pessoais, em que os autores se empenhavam em estabelecer a integridade das vidas individuais; e narrativas em perspectiva destinadas a tornar

\footnotetext{
${ }^{74}$ Ibidem, p. 161.

${ }^{75}$ Ibidem, p. 92.

76 “Certainly many readers of novels were young; most novels were about young people on the verge of making important life decisions about love or career or both, and most seem aimed at readers in similar situations (...) $[\mathrm{N}]$ ovels became, for tens of thousands of young men and woman in eighteenth-century England, guides to many practical decisions about life, the equivalent of family stories and oral tradition in earlier generations and os selfhelp books and films in later ones.” J. Paul Hunter, “The Novel and Social/Cultural History”. In CCEN, p. 20.

77 "Not much of enduring merit came from the turn-of-the-century claim, although most of the celebrated literary works of the early eighteenth century were written in reaction to it.” Hunter, Before Novels, p. 11.
} 
coerentes eventos ou fatos aparentemente sem sentido ${ }^{78}$. Os quatro tipos se manifestavam na forma de tratados religiosos, poemas, peças, panfletos, narrativas curtas e longas, antologias, coletâneas e periódicos. Os romancistas, embora não tenham desenvolvido sua arte pela mera reunião das características dessas formas, escreviam para um público que havia encontrado nelas seu primeiro material de leitura ${ }^{79}$. Eles respondiam, portanto, a um contexto cultural determinado por mudanças socioeconômicas e dominado por textos não necessariamente literários. Hunter dedica um espaço considerável a explorar a relevância de algumas dessas formas — os diários pessoais, as autobiografias, a história, a biografia e os relatos de viagens — para a consolidação das características enumeradas em sua descrição operacional.

O contexto cultural incluía decerto a literatura polida, a que muitos dos novos escritores tentavam se alçar. Mas os augustanos se opuseram às expectativas do grande público, vendo nelas, com justiça, uma ameaça aos valores tradicionais em termos literários e sociais. Rejeitando a oportunidade que o novo mercado apresentava, autores como Dryden e Pope atacaram com virulência os escritores do submundo - que, para Hunter, representavam o futuro literário.

É entre esses excluídos que uma nova concepção, conducente a novas formas, pode se desenvolver. Nem sempre é fácil defender as realizações de gente como Flecknoe, Wotton ou Theobald (embora uma amostra bastante boa da inovação moderna possa ser reunida em Shadwell, Dunton, Defoe, Haywood e Cibber), mas eles estavam ajudando a definir direções que representariam uma nova sensibilidade para a nova era, e que significariam em última instância um espaço para os romances. ${ }^{80}$

\footnotetext{
${ }^{78}$ Idem, p. 86.

${ }^{79}$ Ibidem, p. 217.

80 "It is among these outcasts that a new outlook, conducive to new forms, can develop. It is not always easy to defend the accomplishment of the likes of Flecknoe, Wotton, or Theobald (although a pretty good representation of modern novelty might he assembled from Shadwell, Dunton, Defoe, Haywood, and Cibber), but they were helping to define directions that meant a new sensibility for the new age and that ultimately meant a place for novels.” Idem, p. 163.
} 
McKeon via na prosa de ficção anti-realista uma das faces da exploração simultânea de problemas epistemológicos e sociais que caracterizou, em seu entender, a gênese do romance. Hunter reduz consideravelmente o papel dessa forma no processo de constituição do gênero, mas enfatiza igualmente seu caráter reacionário diante da literatura progressista. Pertençam ou não à genealogia do romance, obras como A História de John Bull são uma réplica a tendências populares que não apenas ameaçavam uma tradição literária já frágil, mas punham em risco valores aristocráticos que vinham sendo abalados pelo fortalecimento de uma nova classe de capitalistas e homens de negócios. Nas palavras de John Richetti:

Muitos romances não apenas representam indivíduos das classes ou fileiras médias da sociedade; eles retratam, na maioria dos casos, tentativas de alcançar status (ou riqueza ou poder) por intermédio da virtude e da ação isoladas e individuais, como opostas à herança ou ao envolvimento coletivo. (...) Nesse mundo, o investidor e empreendedor ousado e versátil é um grande herói, (...) e alguns se converteram, por meio do trabalho duro, da sorte ou amiúde do suborno e da corrupção, em grandes lordes e aristocratas. Nessa emergente ordem socioeconômica, o status está à venda (...). ${ }^{81}$

Em muitos casos o herói dos romances passará bem ainda que sem títulos nobiliárquicos. Nas páginas iniciais de Robinson Crusoé encontramos uma ilustração explícita dessa revalorização social, quando o pai do narrador lhe diz

que a minha era a condição média, ou o que se pode chamar de estrato superior da vida baixa — que, como ele constatara em sua longa experiência, era a melhor condição do mundo, a mais adequada à felicidade humana, não estando exposta às misérias, agruras, labores e sofrimentos da parte mecânica da humanidade, nem comprometida pelo orgulho, luxúria, ambição e inveja

\footnotetext{
81 "Many novels not only represent individuals from the middling ranks or classes of society; they depict more often than not attempts to acquire status (or wealth and power) through isolated and individual virtue and action rather than by inheritance or through corporate involvement. (...) In this world, the daring and resourceful investor and entrepreneur is a great hero, (...) and some men transformed themselves by hard work, luck, or often enough by bribery and corruption into great lords and aristocrats. In this emerging socioeconomic order, in fact but also in imagination, status if for sale (...).” John Richetti, “Introduction”, in The Cambridge Companion to the Eighteenth-Century Novel, p. 7.
} 
da parte superior da humanidade. ${ }^{82}$

82 “(...) that mine was the middle state, or what might be called the upper station of low life, which he had found, by long experience, was the best state in the world, the most suited to human happiness, not exposed to the miseries and hardships, the labour and sufferings of the mechanic part of mankind, and not embarrassed with the pride, luxury, ambition, and envy of the upper part of mankind.” Defoe, Robinson Crusoe, p. 6. 


\subsection{Recapitulação}

Após essas considerações preliminares, que não pretenderam ser breves nem simples, é interessante fazermos um balanço de nossa posição.

O romance forma-se paulatinamente numa época em que a respeitabilidade literária depende de vínculos com a aristocracia e da aceitação de princípios neoclássicos mais gerais. A elite literária da Era Augustana constituía um círculo fechado que dificultava o acesso de escritores sem formação clássica ou com propósitos inovadores. Com o tempo, o aumento do número de leitores nas camadas média e inferior gerou um mercado para textos menos interessados na tradição e nas formas neoclássicas e mais voltados a questões de individualismo e vida quotidiana. Como mostra Hunter, as características que definiriam o romance em sua forma consumada haviam resultado do intercâmbio entre os desejos conscientes ou inconscientes do público e a experimentação de autores marginais - em outras palavras, de um contexto cultural motivado por transformações históricas. Tais características se revelaram em formas anteriores de grande apelo popular, e foram notadas pelos círculos cultos. A prosa de ficção que então se desenvolvia (e que foi designada nessa fase pelos mais variados nomes) foi condenada por sua incompatibilidade com os princípios neoclássicos e por suas tendências socialmente subversivas, vinculada como estava à mentalidade de classe média.

A atitude dos augustanos foi de rejeição, mas eles descobririam nisso a fragilidade de seu apego à tradição. $\mathrm{O}$ credo neoclássico jamais teve pleno vigor entre eles, e na década de 1720 suas formas davam sinal de esgotamento. O envolvimento da aristocracia com a literatura também se tornava menos direto, e a queda do patronato enfraqueceu a posição dos augustanos. A relevância de McKeon para meu estudo está na idéia de que os autores conservadores, em seu esforço por combater as tendências progressistas, precisaram reformular, à luz dos novos desenvolvimentos, um credo tradicional então insustentável. Afastando-se da tradição, eles a usaram não obstante como um meio de combater as novas tendências. Resultou daí uma variedade de prosa de ficção sem grande realismo formal, praticada por autores não vinculados ao espírito de classe média. Esses autores, adeptos do ceticismo extremo e da ideologia conservadora, responderam ao "gênero" que já enxergavam nas narrativas pretensamente verazes dos progressistas. Se suas obras raramente chegam a 
constituir romances, elas representam um contrapeso à tendência que passa por Defoe e culmina em Richardson.

Esse é o espaço de Swift e é o espaço de As Viagens de Gulliver. 
PARTE 2

Swift e Gulliver 


\subsection{As raízes de Gulliver}

O livro foi publicado em 28 de outubro de 1726, sob o auspicioso título de Travels into Several Remote Nations of the World (Viagens a várias nações remotas do mundo). O autor era um certo Lemuel Gulliver, cirurgião de bordo e capitão de vários navios. Até então ninguém nunca ouvira falar dele - o que parecia natural, já que estivera tanto tempo ausente. Em questão de dias ele se tornou assunto obrigatório de cafés, periódicos e clubes literários. "Do nível mais alto ao mais baixo ele é universalmente lido, do conselho do gabinete ao berçário. É consenso entre os políticos que o livro está isento de reflexões particulares, mas que a sátira das sociedades humanas em geral é por demais severa. Não que não encontremos, de quando em quando, gente de maior perspicácia em busca de alusões particulares a cada folha; e é bastante provável que se publiquem chaves para projetar luz sobre os intuitos de Gulliver." ${ }^{83}$ A popularidade inicial não foi efêmera. Os dois meses seguintes trouxeram duas reimpressões, e em 1727 o livro foi "corrigido", serializado e traduzido para o francês, o holandês e o alemão. Ele superaria a vendagem de Robinson Crusoé e se tornar o maior best seller inglês do século XVIII. O tom tumultuoso dessa carreira foi ditado desde o início, com a polêmica sobre quais seriam os alvos do livro e com que justiça eram atacados. A princípio Swift foi cauteloso e preservou o anonimato, mas em dezembro de 1727 assumiu a autoria numa carta a Benjamin Motte, o editor. Em 1735 Gulliver foi reimpresso em Dublin por George Faulkner, incluindo dessa vez passagens mais acerbas que Motte eliminara por prudência de sua edição. Nesses anos de grande tensão no mundo editorial, era praxe julgar os produtos literários de acordo com sua bandeira política. Os conhecidos elos de Swift com os tories confirmaram as reservas dos whigs, e estes retaliaram com virulência. Por décadas a fio a atividade crítica julgaria Gulliver como documento político, e seu valor como obra literária só receberia uma atenção marginal. Quando feita pela crítica whig, a análise do livro se

\footnotetext{
83 "From the highest to the lowest it is universally read, from the Cabinet-council to the Nursery. The Politicians to a man agree, that it is free from particular reflections, but that the Satire on general societies of men is too severe. Not but we now and then meet with people of greater perspicuity, who are in search for particular applications in every leaf; and it is highly probable we shall have keys published to give light into Gulliver's design.” Carta de John Gay a Swift, 17 de novembro de 1726. In GT, p. 266.
} 
convertia num exercício de aviltamento, e muito da fama de misantropo que coube a Swift se deveu à mistura deliberada entre suas opiniões e as de Gulliver, como se o livro fosse um manifesto franco e direto das visões do autor — enfim, um panfleto político. A idéia é parcialmente verdadeira, mas obscurece os fatos de que Gulliver não é um porta-voz de Swift e de que este último, para além de suas motivações políticas, também estava empenhado numa importante campanha cultural - campanha que incluiu nesses anos a Duncíada, de Pope, e A Ópera do Mendigo, de Gay. As Viagens de Gulliver são, sim, um documento político, mas não constituem uma expressão direta das convicções pessoais de Swift, nem se restringem ao campo da política. Com o tempo, a crítica passaria a dar atenção a outros aspectos do livro, reconhecendo que em Gulliver confluem interesses políticos e culturais cujas raízes em grande medida se entrelaçavam.

O período de composição do livro foi por muito tempo um objeto de conjectura. Desde a publicação das cartas de Swift a Charles Ford, em 1935, sabemos que ele foi escrito na Irlanda entre 1721 e 1725 e corrigido provavelmente até sua publicação. Após seis anos de quase absoluto silêncio, durante os quais Swift se concentrara em seus deveres como deão da Catedral de São Patrício, esse período assinalou seu retorno ao campo da polêmica impressa. Mas o material que ele utilizou em Gulliver não provinha necessariamente dos anos de escritura. Note-se, por exemplo, o papel proeminente da guerra no fio satírico do livro - e todavia a Grã-Bretanha na década de 1720 estava sob a política de paz de Walpole. O mesmo não se pode dizer do período que precedeu o silêncio autoral de Swift: os últimos anos da rainha Ana, desfecho da Guerra da Sucessão Espanhola. É a esse período - e especificamente aos anos entre 1710 e 1714 - que remonta não somente a crítica de Swift à guerra, mas também a essência de sua sátira política e literária.

\subsubsection{Raízes políticas}

A escolha dos anos 1710-1714 não é casual. Nessa época Swift esteve em Londres em missão da igreja e firmou os principais elos políticos e literários de sua carreira, respectivamente com os tories e o Scriblerus Club. Dessa época datam os conhecidos retratos de Jervas, em que vemos Swift no auge de suas forças, empenhado na luta pelos valores que lhe eram mais caros. Tais valores (essencialmente a supremacia da igreja anglicana, o ideário 
conservador e a concepção augustana de literatura) enfrentavam então um momento crítico. Contra eles se elevavam as reivindicações dos dissidentes, o poder liberal dos novos capitalistas e uma nova corrente literária que, como já pudemos verificar, vinha se afirmando junto ao público burguês. Num dos períodos mais claramente bipartidários da história inglesa, era natural que os conflitos religioso, político e literário convergissem na oposição mais elementar entre tories e whigs. Swift, originalmente associado aos últimos, acabou atrelando seu destino ao dos primeiros.

Isso não envolveu necessariamente uma traição de princípios. Antes de mais nada, não é tarefa simples determinar se Swift era por definição tory ou whig, especialmente em se considerando o sentido instável desses termos na época ${ }^{84}$. Em sua biografia de Swift, o Dr. Johnson observaria: “ele reteve por toda a vida a disposição que atribui ao Homem da Igreja Anglicana — a de pensar em comum com os whigs do Estado e com os tories da Igreja”85. Tornou-se comum definir as inclinações de Swift por meio dessa fórmula, já que ela resolve a inconsistência entre seu apoio à Igreja Anglicana (típico dos tories) e à supremacia do legislativo (típico dos whigs). O próprio Swift nos autoriza a pensar assim numa passagem das Memoirs Relating to the Queen's Last Ministry:

Familiarizado desde há muito com os autores gregos e romanos, e sendo portanto um amante da liberdade, descobri-me bastante propenso a ser o que denominam um whig em política; de mais a mais, eu julgava impossível, com base em qualquer outro princípio, defender ou aceitar a revolução; em matéria de religião, porém, eu me confessava um membro da Alta Igreja, e não concebia como alguém que trajasse o hábito clerical poderia agir de outro modo. ${ }^{86}$

\footnotetext{
${ }^{84}$ Cf. David Oakleaf, “Politics and History”. In CCJS, p. 38.

85 "he continued throughout his life to retain the disposition which he assigns to the Church-of-England Man, of thinking commonly with the Whigs of the State, and with the Tories of the Church". Samuel Johnson, "Swift", em The Lives of the Poets, p. 221. Ver de Swift The Sentiments of a Church-of-England Man, with Respect to Religion and Government (1711).

86 "having been long conversant with the Greek and Roman authors, and therefore a lover of liberty, I found myself much inclined to be what they called a Whig in politics; and that, besides, I thought it impossible, upon any other principle, to defend or submit to the revolution: But as to religion, I confessed myself to be an High-
} 
E todavia essa fórmula desconsidera a estreita ligação então vigente entre Igreja e Estado. Ser um whig em política significava aprovar um sistema de empréstimos públicos que submetia o Estado à influência do Banco da Inglaterra e por conseguinte de capitalistas de origens presbiterianas. Esses financistas naturalmente pressionavam o parlamento por maior tolerância aos dissidentes, abalando com isso a estabilidade da Igreja Anglicana. Durante suas negociações prévias com os whigs, Swift já havia constatado que o preço destes para as concessões fiscais requeridas pela Igreja da Irlanda seria a suspensão da Lei do Teste Sacramental em território irlandês — o que na prática equivaleria a abrir os escalões do governo a todas as seitas protestantes que ele desprezava ${ }^{87}$. Por outro lado, embora a oposição partidária entre whigs e tories estivesse então no auge, sua oposição ideológica já não era tão absoluta como na época da Crise da Exclusão (1679-1681), quando mais não fosse porque a idéia de submissão a um rei por direito divino saíra de cena: os tories do novo reinado excetuada sua ala radical — não desejavam abolir a Revolução de 1688, mas modificá-la em prol dos proprietários de terras ${ }^{88}$. Isso significa que associar-se aos tories já não significava renegar a revolução (ou, em outras palavras, a restrição dos poderes do rei pelo parlamento). Quando Swift descobriu em Robert Harley um secretário de Estado moderado, afável, culto e, acima de tudo, disposto a negociar sem exigir concessões nocivas à Igreja, ele não teve dúvidas e apostou a sorte com os tories ${ }^{89}$.

A situação nos anos 1710-1714 pode ser resumida assim: uma guerra custosa e prolongada grassava na Europa, alinhando a Inglaterra, a Holanda e o Império num esforço por impedir a anexação do legado espanhol pela França de Luís XIV. Esse conflito, conhecido como Guerra da Sucessão Espanhola (1701-1713), foi o tema central da discussão política no reinado de Ana. O envolvimento direto da Inglaterra tinha a aprovação dos comerciantes londrinos, que lucravam imensamente com os esforços bélicos, e era condenado pela gentry, que penava sob uma taxação crescente em tempos de recessão agrária. Os interesses da esfera

Churchman, and that I did not conceive how anyone, who wore the habit of a clergyman, could be otherwise.” In David Nokes, Jonathan Swift: A Hypocrite Reversed, p. 56.

${ }^{87}$ A importância dessa lei na decisão de Swift de se afastar dos whigs fica patente em A Letter on the Sacramental Test (1708).

${ }^{88}$ G. M. Trevelyan, England Under the Stuarts, p. 392.

${ }^{89}$ Cf. The Journal to Stella, nas seções de setembro de 1710. 
comercial estavam incorporados nos whigs, que propeliram a máquina de guerra até 1710; os da gentry eram promovidos pelos tories, que a partir de 1710 se empenharam em negociar a paz. Dois fatores tornaram especialmente clamorosa a disputa entre as duas facções: o primeiro foi a Lei Trienal de 1694, que resultou em eleições parlamentares mais freqüentes e deixou o governo mais vulnerável a flutuações de ânimo no eleitorado; o segundo foi a caducidade da Lei de Licenciamento em 1695, que suspendeu a censura estatal e deu novo alento à imprensa periódica. Ambos os partidos se valeram da recém-adquirida liberdade de imprensa para assegurar o favor da opinião pública, e o resultado foi uma época de ouro para a panfletagem política. Robert Harley e Henry St. John ${ }^{90}$, líderes dos tories que venceram as eleições em 1710, teriam a seu serviço alguns dos mais talentosos panfletistas políticos da história inglesa — entre os quais Defoe e Swift.

A ligação de Swift com os tories envolveria portanto a composição de panfletos anônimos destratando os whigs e os esforços de guerra. Os principais desses textos foram os que ele escreveu para o periódico The Examiner (1710-11) e panfletos independentes como The Conduct of the Allies (1711), cujo objetivo era reduzir os escrúpulos do público no caso de uma paz unilateral com a França, que deixaria ao léu os aliados britânicos. Essa atividade, longe de venal, permitia a Swift dar vazão a um desprezo sincero pelos capitalistas urbanos:

Há vinte anos a nação tem gemido sob o fardo intolerável daqueles que lhe sugam o sangue em proveito próprio. Promovemos guerras apenas para encher os bolsos de especuladores. Revisamos nossa constituição e, graças a um grande e unívoco esforço nacional, asseguramos nossa sucessão protestante, somente para nos tornar ferramentas de uma facção que se arroga todo o mérito do que foi um ato da nação. Somos governados por arrivistas que vêm abalando os alicerces de nosso sistema social e substituindo a influência da gentry fundiária pela de uma classe de homens que descobre seus lucros em nossos males. Se o ministério recém-deposto representava algo, era isso. E a mudança que ora adveio despertará na nação o senso de seus erros, restabelecerá a devida influência da gentry e nos livrará do enxame pestilento de especuladores confederados com os whigs (...) homens que, com o espírito de merceeiros, vêm

\footnotetext{
${ }^{90}$ Respectivamente os futuros conde de Oxford e visconde de Bolingbroke.
} 
moldar regras para a administração de reinos. ${ }^{91}$

Ficam claras aqui as principais simpatias de Swift: ele está ao lado dos grandes proprietários de terras — a seu ver os verdadeiros donos da nação — , e vê nos novos capitalistas londrinos uma súcia de aproveitadores que se apossou do poder da gentry sem herdar-lhe as responsabilidades. Essa é uma posição perfeitamente compatível com um "homem da Alta Igreja”, já que os comerciantes ricos eram em grande parte membros de seitas dissidentes cujo acesso a outras profissões fora barrado pela legislação. Outros princípios - como a oposição à permanência do exército em tempos de paz, a crítica ao excesso de poder do executivo e a defesa de uma política não intervencionista — já vinham sendo absorvidos pelos tories moderados desde os tempos de Guilherme III $^{92}$. Swift, por tudo isso, não estava renegando seus princípios ao se pôr a serviço de Harley. Não se entenda, tampouco, que ele fosse uma espécie de empregado do ministério. Swift sempre exigiu que Harley o visse como um aliado numa missão comum. Em The Journal to Stella, a coletânea de cartas que escreveu a Esther Johnson durante sua longa estada em Londres, ele deixou claras suas esperanças de se alçar a uma alta posição — talvez a um bispado — no caso de sucesso dos tories ${ }^{93}$. Mais do que suas convicções religiosas e políticas, estavam em jogo suas ambições de carreira.

Os tories, no entanto, vinham fazendo uma cartada perigosa. O favor de uma rainha anglicana e avessa à guerra os amparava pelo momento, mas Ana não viveria muito. A sucessão ao trono no caso de ela morrer sem filhos fora definida pela Lei de Estabelecimento de 1701: a coroa caberia ao eleitor de Hanôver, descendente direto de Jaime I. Ficavam

\footnotetext{
91 "For twenty years the nation has groaned under the intolerable burden of those who sucked her blood for gain. We have carried on wars, that we might fill the pockets of stock-jobbers. We have revised our Constitution, and by a great and united national effort, have secured our Protestant succession, only that we may become the tools of a faction, who arrogate to themselves the whole merit of what was a national act. We are governed by upstarts, who are unsettling the landmarks of our social system, and are displacing the influence of the landed gentry by that of a class of men who find their profit in our woes. If the late discarded Ministry represented anything, they represented this: and the change that has now come, will awaken the nation to a sense of its mistakes, will recover the rightful influence of the landed gentry, and will rid us of the pestilential swarm of stock-jobbers who are confederate with the Whigs.” The Examiner, XXI. Em Henry Craik, The Life of Jonathan Swift, V. I, p. 267.

92 Ian Higgins, “Swift's Politics: A Preface to Gulliver’s Travels”, reproduzido em Claude Rawson (ed.), Jonathan Swift: A Collection of Critical Essays, p. 185; e David Nokes, op. cit., p. 270.

${ }^{93}$ The Journal to Stella, XVI, 17 de fevereiro de 1711.
} 
excluídos da linha de sucessão quaisquer católicos, inclusive o filho de Jaime II, que então vivia na corte francesa e tinha o apoio de Luís XIV. O dilema dos tories foi que, ao promoverem o fim da guerra à revelia dos aliados, eles se indispuseram com o futuro rei hanoveriano, que então lutava ao lado do Império. Mais que isso: a casa de Hanôver tinha interesse em que a guerra prosseguisse até depois da morte de Ana, o que manteria o pretendente Stuart associado aos inimigos da nação inglesa e reduziria suas possibilidades de reclamar a coroa. O resultado era que “qualquer paz seria jacobita por implicação"94. Os tories, que desde há muito eram considerados jacobitas pelos whigs, viram-se obrigados a considerar em segredo a sucessão de Jaime III, que Bolingbroke tentou inutilmente dissuadir do credo católico. Harley, ponto de conexão entre a ala radical de seu partido e os whigs, manteve um jogo duplo que iludiria a muitos, inclusive a Swift. Seu partido se via paradoxalmente na condição de um defensor da Igreja Anglicana que cortejava um sucessor católico. Quaisquer esperanças que eles tivessem de fraudar os termos da sucessão foram arruinadas pela morte súbita de Ana. Os whigs souberam se valer da ocasião, e a sucessão de Jorge I de Hanôver ocorreu sem percalços. Harley foi confinado à Torre, Bolingbroke exilouse na França e os tories recuaram para um plano secundário do qual não sairiam senão meio século mais tarde.

Swift foi enredado na desgraça do partido. Em 1713 já ficara claro que seus anseios de sagrar-se bispo eram vãos, e ele se resignou ao decanato da Catedral de São Patrício, numa Dublin que detestava. Sua pena também silenciara: o panfleto The Public Spirit of the Whigs (1714), que ele compusera em resposta a Steele durante a polêmica da sucessão, desagradara às autoridades por deslustrar os lordes escoceses, e a identidade do autor foi posta a prêmio ${ }^{95}$. Desde antes da queda sua confiança na proteção do ministério já estava abalada. Ele regressou à Irlanda sob suspeitas de jacobitismo, e durante anos teria sua correspondência pessoal esmiuçada às ocultas por agentes do governo. Não voltaria a publicar tão cedo. Esse silêncio se explica, como se vê, por um misto de precaução e desilusão. Em 1714 tinha fim sua fase de esplendor. Sem que Swift soubesse, seu regresso a Dublin seria definitivo. Salvo por raras visitas à Inglaterra, ele permaneceria na Irlanda até seus últimos dias, "para morrer feito um

\footnotetext{
${ }^{94}$ Kenyon, Stuart England, p. 343.

${ }^{95}$ Cf. Paul Hyland, “Richard Steele: Scandal and Sedition”, em Writing and Censorship in England, p. 67-69.
} 
rato envenenado numa toca”,

Entre 1715 e 1720 ele não publicou mais nada; não significa, contudo, que não tenha escrito nada. Dessa época datam várias obras de publicação posterior, entre as quais a History of the Four Last Years of the Queen, as Memoirs of that Change Which Took Place in the Queen's Ministry in the Year 1710 e An Enquiry into the Behaviour of the Queen's Last Ministry. São textos históricos que buscam inocentar o ministério a que ele estivera associado nos anos anteriores; na época, eram impublicáveis. Este fato demonstra que para Swift o debate entre whigs e tories estava longe de encerrado. O que faltava era trazê-lo de novo à arena pública. E isso Swift faria após seu sucesso inicial nas questões da Irlanda. A indignação pelo modo como o governo inglês tratava o país que lhe coubera como lar acabou rompendo seu silêncio. Ele promoveu uma verdadeira batalha impressa contra as restrições comerciais impostas à Irlanda, contra o absenteísmo dos governantes, contra a submissão do parlamento irlandês ao inglês — e, mais essencialmente, contra um governo corrupto que se perpetuava sob o amparo dos dois primeiros Jorges. "O que ele de fato ganhou com seu envolvimento na política irlandesa foi uma plataforma da qual confrontar seus velhos inimigos do establishment whig na Inglaterra”97. Em 1724 ele logrou um de seus maiores sucessos com as Drapier's Letters, uma série de panfletos em forma epistolar que mobilizou a opinião pública irlandesa contra a adoção de uma moeda de cunhagem inferior que lhes seria imposta pelo governo inglês. A importância das Drapier's Letters transcendeu em muito a questão pecuniária que lhes dera origem: elas constituíam um manifesto da resistência irlandesa aos abusos de um governo whig que tratava a Irlanda como uma colônia sem arbítrio. A lenda do nacionalista deão de São Patrício deveu muito a esse episódio, e foi com esse novo estímulo que Swift deu início à redação de As Viagens de Gulliver, culminação portanto da prolongada campanha que seu autor vinha promovendo desde os fatídicos anos do ministério tory ${ }^{98}$.

\footnotetext{
${ }^{96}$ Carta a Bolingbroke, 21 de março de 1729.

${ }^{97}$ David Nokes, "Swift and the Beggars”, reproduzido em Harold Bloom (ed.), Jonathan Swift: Modern Critical Views, p. 134.
} 


\subsubsection{Raízes literárias}

O que talvez intrigue é que Swift, que em questões políticas pronunciara-se sobretudo em panfletos dissertativos, tenha optado em Gulliver por uma narrativa ficcional. Procurar pronunciamentos de Swift sobre o valor desta ou daquela forma literária costuma ser um exercício frustrante. Quando muito ele comenta questões de estilo, como em A Proposal for Correcting, Improving and Ascertaining the English Tongue (1712) e A Letter to a Young Gentleman, lately entered into Holy Orders (1720). O texto que durante muito tempo constituiu um de seus testemunhos mais detalhados sobre questões literárias - A Letter of Advice to a Young Poet (1721) — é hoje tido como apócrifo. O que nos restam são sobretudo juízos avulsos e o que se pode deduzir de sua prática como escritor. As preferências que daí resultam são escrupulosas. Ao teatro, por exemplo, Swift não ia, e sabemos que só leu as peças de seu amigo Congreve por uma curiosidade ociosa ${ }^{99}$. E à prosa de ficção de seu tempo ele em geral se mostra hostil. Nas Directions to Servants, encontramos a seguinte recomendação (jocosa) às tutoras ou governantas:

Façam com que as senhoritas leiam romances ingleses e franceses, histórias romanescas francesas e todas as comédias escritas na época dos reis Carlos II e Guilherme, para abrandarlhes a natureza e deixá-las de coração terno. ${ }^{100}$

A Letter to a Young Lady sugere igualmente a incompatibilidade entre moças e romances; em notas manuscritas intituladas Hints: Education of Ladyes, ele escreveu: "Nada de romances franceses, e poucas peças para as senhoritas”"101; e a criada que causou o incêndio no palácio de Lilliput estava distraída "lendo um romance”"102. Igualmente sugestivo é o histórico de

\footnotetext{
${ }^{98}$ Cf. Ricardo Quintana, Swift: An Introduction, p. 22; Irvin Ehrenpreis, The Personality of Jonathan Swift, p. 8485; Simon Varey, "Exemplary History and the Political Satire of Gulliver's Travels”, in GGT, p. 48;

${ }^{99}$ Cf. The Journal to Stella, carta XXXIII, p. 322.

100 "Make the misses read French and English novels, and French romances, and all the comedies writ in King Charles II. and King William's reigns, to soften their nature, and make them tender-hearted.” In Eddy (ed.), Swift's Satires and Personal Writings, p. 250.

101 “No French Romances, and few plays for young Ladyes.” Cf. Turner (ed.), Gulliver’s Travels, p. 301.

102 “reading a romance”. GT, I, v.
} 
leituras e o acervo da biblioteca de Swift. Um levantamento feito por Brean Hammond com base numa lista deixada por Swift e nos inventários de seus livros revela um relativo descaso pela produção mais recente de obras de imaginação. Em 1696/7, suas leituras incluíram Homero, Petrônio, Horácio, Virgílio, Lucrécio, Cícero, Eliano, Diodoro Sículo, São Cipriano e Santo Irineu; e entre escritores ingleses recentes, Temple (seu patrão), Burnet e Blackmore (dois autores que ele desdenhava, e que provavelmente lera por sarcasmo). Sua biblioteca era bem abastecida de historiadores e teólogos, mas deficiente em outros sentidos. Shakespeare e Butler, por exemplo, não figuram em nenhum dos inventários disponíveis. "Isso tudo confirma que a biblioteca de Swift não era primariamente a de um literato: e por esta observação sensacional quero dizer que ele não colecionava energicamente as obras de imaginação de autores contemporâneos.”103 Não significa que Swift não lesse tais autores; eles simplesmente não atendiam a seus critérios seletivos. "Ele havia lido Defoe, mas não o queria em suas estantes.”104 Para além disso, as leituras e a biblioteca de Swift sugerem que a prosa de ficção, tal como praticada em seu tempo, não era de modo algum o gênero em que ele pretendia aplicar suas forças.

Antes de se tornar o satirista e panfletista político que tomou Londres de assalto em princípios do século XVIII, Swift tivera ambições literárias mais ortodoxas. Nascido e criado em condições medianas, ele ambicionou o prestígio dos luminares das letras da Restauração. Assim confessou a Pope:

"E digo-lhe ainda que, desde menino, todos os meus esforços por destacar-me se deveram à falta de título e fortuna, para que eu pudesse ser tratado como um senhor pelos que fizessem conta de meus talentos - se justa ou injustamente, não importa. E com isso, a reputação por espírito ou erudição faz as vezes de uma faixa azul ou de um coche de três parelhas”"105

\footnotetext{
103 "All of these confirm that Swift's library was not primarily that of a literary man: by which sensational remark, I mean that Swift did not energetically collect the writings of contemporary imaginative writers.” Hammond, “Swift's Reading”. In CCJS, p. 75.

104 “He had read Defoe, but he did not want him on his shelves.” Idem, p. 85.

105 "I will farther tell you that all my endeavours from a boy to distinguish myself, were only for want of a title and fortune, that I might be used like a lord by those who have an opinion of my parts; whether right or wrong, it is no great matter; and so the reputation of wit or great learning does the office of a blue ribband, or of a coach and six horses.” Carta a Pope, em 5 de abril de 1729. In Craik, The Life of Jonathan Swift, V. I, p. 170.
} 
A ambição de Swift é a do augustano por excelência, e ele cresceu envolvido pela atmosfera do neoclassicismo e do culto aos antigos. A formação que ambicionava lhe foi proporcionada pelo convívio com Sir William Temple, esse famoso defensor da Antigüidade, a quem ele serviu como secretário entre 1689 e 1699. A rica biblioteca de Temple e o mundo polido de Moor Park cimentaram seus interesses. Podemos inferir daí que o desprezo corrente pela prosa de ficção influiu em sua formação. Luciano, Rabelais e Cervantes estavam entre seus favoritos, mas nesse caso o registro é outro: nesses autores a ficção está a serviço da sátira, e não incorre na problemática mistura de estilos. Ademais, eles o ajudariam a descobrir sua veia satírica. Até então as tentativas literárias de Swift haviam sido comportadas - e de sobejo frustradas, como observou famosamente o Dr. Johnson:

Desde cedo Swift começou a achar ou a sonhar que era poeta, e escreveu odes pindáricas a Temple, ao rei e à Sociedade Ateniense (...). Contaram-me que Dryden, após examinar esses versos, disse: "Primo Swift, você jamais será um poeta"; e que tal denúncia foi o motivo da perpétua malevolência de Swift para com Dryden. ${ }^{106}$

Swift acabaria descobrindo que sua voz era outra, e já nos anos de Moor Park compôs as duas grandes sátiras que seriam publicadas em 1704: O Conto do Tonel e A Batalha dos Livros. Juntamente com os Bickerstaff Papers, essas sátiras o tornaram famoso em Londres e o agraciaram junto à intelectualidade da época. O vínculo com Harley lhe permitiu passar das sátiras e dos poemas cômicos a projetos mais sérios, como sua Proposal for Correcting, Improving and Ascertaining the English Tongue (1712). "Minha carta ao Lorde Tesoureiro sobre a língua inglesa está agora nas prensas, e permito que meu nome seja incluído ao final, coisa que jamais fiz em minha vida”107. Nessa mesma época veio-lhe o anelo de compor

\footnotetext{
${ }^{106}$ Swift began early to think, or to hope, that he was a poet, and wrote Pindarick Odes to Temple, to the King, and to the Athenian Society (...). I have been told that Dryden, having perused these verses, said, 'Cousin Swift, you will never be a poet'; and that this denunciation was the motive of Swift's perpetual malevolence to Dryden.” Johnson, “Swift”, em The Lives of the Poets, p. 195.

107 Na verdade ele assinara a Ode to the Athenian Society e a dedicatória das obras de Temple, mas aparentemente preferia esquecer o fato. No original: "My letter to Lord Treasurer, about the English Tongue, is
} 
seriamente obras históricas. "Suspeitamos que sua ambição não era tanto escrever As Viagens de Gulliver como escrever uma história de seu tempo menos implacavelmente whig do que a de Burnet.”108 Talvez tenha sido esse o momento em que Swift chegou mais perto de concretizar suas grandes aspirações como homem de letras.

Mas os projetos não vingaram: a proposta filológica não teve o apoio do governo e os textos históricos, após escritos, seriam engavetados. Depois da queda dos tories em 1714, o apoio político ao exercício das letras (dependente como fora da oposição entre os dois partidos) entrou em decadência. Walpole só contrataria panfletistas baratos e confiaria no suborno como alavanca de influência. Um número excessivo de escritores passou a disputar um número reduzido de patronos das artes, e como resultado a senda literária da Restauração foi se estreitando. O autor que até então praticara os gêneros polidos confiando no esteio firme da corte viu-se dependente da venda dos livros, o que significava compactuar em certa medida com os gostos do grande mercado ${ }^{109}$. Muitos encontraram uma saída para o dilema no sistema de subscrição: o autor, antes de empreender um projeto, recolhia assinaturas de leitores interessados, que deviam pagar metade do valor final de venda. Com isso era possível garantir de antemão a viabilidade do livro e selecionar o público para o qual se escrevia. Foi a subscrição que assegurou a independência autoral de Pope, graças ao sucesso estrondoso de suas traduções de Homero. Já outros autores preferiram fazer concessões. É nessas circunstâncias que os escritores cultos passam a aceitar a prosa de ficção como uma opção artística e economicamente interessante. Sintomas disso são o fato de que Fielding escreva romances depois que o teatro se torna impraticável e que Johnson componha Rasselas para pagar o enterro da mãe. Swift, que desde o declínio dos tories vinha evitando publicar, retornou ao prelo já sob o novo clima. As Viagens de Gulliver, que Ehrenpreis considerou a "sublimação de panfletos e fragmentos suprimidos”"110, representaram um desvio de rota

now printing; and I suffer my name to be put at the end of it, which I never did before in my life.” The Journal to Stella, carta XLIV, p. 437.

108 “One suspects that his ambition was not so much to write Gulliver's Travels as to write a history of his own times less relentlessly whiggish than Burnet's”. Hammond, op. cit., p. 81.

109 Cf. Pat Rogers, “Books, Readers and Patrons”, in FORD, Boris (ed.) From Dryden to Johnson; Hauser, História Social da Arte e da Literatura, VI, 2; Humphreys, “The Literary Scene”, in FORD, Boris (ed.), op. cit., e The Augustan World - Life and Letters in Eighteenth Century England, p. 93.

110 “a sublimation of the supressed pamphlets and fragments”. Ehrenpreis está pensando especificamente em Lilliput. The Personality of Jonathan Swift, p. 91. 
motivado pelas preferências do público e pelo desejo de se fazer ouvir mais amplamente.

Mas a escolha da prosa de ficção, e mais particularmente do relato de viagens, foi tudo, menos dócil. Swift tinha perfeita ciência da associação dessa forma com a classe mercante de seus inimigos. Os motivos que o levaram ainda assim a escolhê-la remontam aos tempos do Scriblerus Club. A primeira onda de inovação literária descrita por Hunter tinha um forte pendor whig. Ela constituiu uma alternativa ao augustanismo proposta por escritores que se empenharam em "identificar as formas e modelos literários adequados a uma nação que, com a Revolução Gloriosa de 1688, alcançara a liberdade política e entrara em posse de si mesma”"111. A escolha desse marco histórico como data de renovação literária era muito significativa. Ao passo que os augustanos viam o ponto de transição em 1660 e tinham em Carlos II seu herói, esses novos autores (como Sir Richard Blackmore, Charles Gildon e John Oldmixon) optavam alternativamente por 1688 e Guilherme III - o que implicava a tolerância religiosa, o estímulo ao comércio e o combate à França. Eles desconsideravam o vínculo com a Antigüidade e buscavam seu material e sua inspiração na nova Inglaterra, em seus feitos, seus generais, sua grandeza. Essa opção antitradicionalista foi combatida pelos tories e especialmente pelo Scriblerus Club, a associação literária concebida por Swift e Pope em 1714 como antídoto à predominância dos whigs nos cafés. Formado por Harley, Pope, Swift, Gay, Parnell e Arbuthnot, o Scriblerus Club se dedicou a aviltar seus oponentes literários com o mito do borra-papéis, um mito essencialmente tory que

afirmava deplorar a moderna cultura inglesa e a escrita que ela havia fomentado. Alienada do que havia de melhor nas tradições clássica e nativa, essa escrita era apresentada como obra menos de artistas que de mercadores de palavras. Ela por conseguinte estava presa à mediocridade. $^{112}$

\footnotetext{
111 "to identify the literary forms and models appropriate to a nation which, with the Glorious Revolution of 1688, had grasped its political liberty and entered into possession of itself.” David Womersley, no prefácio a Augustan Critical Writing, p. xiv.

112 "it claimed to deplore modern English culture and the writing it had fostered. Estranged from the best in both the classical and the native traditions, this writing was presented as the work of tradesmen in words rather than artists. It was consequently imprisoned within mediocrity.” Womersley, op. cit., p. xiv.
} 
O principal produto do clube seriam as Memoirs of Martinus Scriblerus, escritas em colaboração pelos membros e publicadas em 1741 na edição das obras completas de Pope. Seu propósito era “ridicularizar todos os falsos gostos em erudição, na figura de um homem de suficiente capacidade que se houvesse aprofundado em toda arte e ciência, mas insensatamente em ambos os casos" ${ }^{\text {113 }}$. O movimento dos scriblerianos constituía no campo literário algo similar à reação tory no campo político. Um de seus produtos tardios — a Duncíada de Pope - é uma aberta flagelação de escritores associados às novas tendências (entre os quais encontramos Defoe ${ }^{114}$ ). A queda do ministério foi entretanto fatídica: ela levou ao desmembramento do Scriblerus Club e, assim como havia debilitado a panfletagem política, atravancou o projeto de reforma literária.

As Memoirs of Martinus Scriblerus continuaram a ser compostas muito lentamente, com contribuições ocasionais de um que outro membro. Um dos capítulos previstos na sátira geral envolveria as viagens de Martinus a diversos países. Swift, cuja participação no projeto era ocasionalmente solicitada nas cartas de Arbuthnot, provavelmente pretendia se incumbir da descrição dessas viagens — algo que já lhe passara pelo espírito e que de resto estava mais de acordo com seus talentos que os demais elementos das Memoirs ${ }^{115}$. A idéia teria de esperar que ele recobrasse o ânimo da escrita. Em Gulliver Swift retomaria esse ponto de partida, refinando-o e conferindo-lhe fôlego e intensidade. A obra que acabou escrevendo transcende em muito as “viagens” originais, mas preserva elementos scriblerianos, sobretudo no Livro III. E a proposta básica igualmente se preservou. “As Viagens de Gulliver são totalmente scriblerianas em suas atitudes intelectuais básicas e até mesmo, excetuadas as referências às questões irlandesas, em seus específicos objetos de sátira.” ${ }^{\circledR 16}$ Isso tudo significa que Swift não recorreu ao relato de viagens por alguma confiança recém-descoberta no valor desse gênero. O germe de Gulliver era por natureza combativo, e cresceu com a obra. A prosa de

\footnotetext{
113 "to have ridiculed all the false tastes in learning, under the character of a man of capacity enough; that had dipped into every art and science, but injudiciously in each”. Joseph Spence, com base em confidências de Pope, em Anecdotes, Observations, and Characters, of Books and Men, seção I. In MMS, p. 363.

114 “The Dunciad”, II, v. 147. Pope, Selected Poetry, p. 141.

${ }^{115}$ Os trechos de sátira científica cabiam naturalmente a Arbuthnot, e outros tópicos, como a crítica e a poesia, já haviam sido suficientemente cobertos por Pope e Gay. Cf. Kerby-Miller, MMS, p. 316.

116 “Gulliver's Travels is thoroughly Scriblerian in its basic intellectual attitudes and even, with the exception of the references to Irish affairs, in its specific objects of satire.” Kerby-Miller, MMS, 320.
} 
ficção de Swift não compactuaria com a de seu tempo, pois a sua era uma adesão deletéria — a adesão, por assim dizer, de um vírus.

Tais as raízes políticas e literárias de Gulliver. Vê-se que elas se ligam intimamente: a postura de Swift como escritor reflete seu vínculo duradouro com uma certa classe e um certo partido. Ao ganharem expressão no livro, sua crítica política e sua crítica literária preservaram os laços originais. Isso significa que em Gulliver — para empregar os termos de McKeon —, o meio de dizer a verdade na narrativa associa-se a uma certa estimativa da virtude dos indivíduos. E é a isso que me voltarei agora. 


\subsection{Verdade e virtude}

Hoje nós geralmente sabemos, antes mesmo de ler o livro, que Gulliver é o gigante em terra de anões. Mas qual terá sido a reação do leitor de 1726, que abordou o texto sem sobreaviso? Podemos imaginá-lo adquirindo seu exemplar ou tomando-o emprestado (os livros afinal eram caros), percorrendo os parágrafos biográficos que abrem a narrativa e, desde que fosse um leitor experimentado, deixando-se tomar pelo déjà vu — pela impressão de que repetiam-se ali as viagens descritas por Richard Hakluyt ou William Dampier. Ele provavelmente alargaria os olhos ao primeiro naufrágio e então depararia este trecho, em que Gulliver está estendido, imóvel, numa costa anônima:

Passado pouco tempo senti que algo vivo se movia em minha perna esquerda, algo que, avançando gentilmente por meu tórax, chegou-se-me próximo ao queixo. Nisso, baixando meus olhos tanto quanto pude, percebi que era uma criatura humana com menos de seis polegadas de altura, de arco e flecha na mão e aljava nas costas. Entrementes, senti pelo menos outros quarenta da mesma espécie (ao que conjecturei) seguindo-se ao primeiro. ${ }^{117}$

A pergunta é: como reagiu nosso leitor hipotético? Quero presumir que continuou lendo, a ver se Gulliver tresvariava ou se realmente vira os homenzinhos. A primeira hipótese ele logo se vê forçado a descartar. Os parágrafos que se seguem são obstinadamente factuais: Gulliver não parece estranhar de modo algum os prodígios que relata. Ele prossegue em seu estilo detalhista e pés-no-chão, contando como os liliputianos o dominaram, deram-lhe de beber num tonel e finalmente o carregaram até sua capital, num colossal engenho para o transporte de toras. Tudo isso no tom de quem narra um passeio no parque.

\footnotetext{
117 "In a little time I felt something alive moving on my left Leg, which advancing gently forward over my Breast, came almost up to my Chin; when, bending my Eyes downwards as much as I could, I perceived it to be a human Creature not six inches high, with a Bow and Arrow in his Hands, and a Quiver at his Back. In the mean time, I felt at least forty more of the same kind (as I conjectured) following the first.” GT, I, i, p. 17.
} 


\subsubsection{Viagens verdadeiras?}

Então o leitor se pergunta: isso tudo é verdade?

Se nos limitássemos ao método de exposição, poderíamos responder que sim. O livro procura por todos os meios rechaçar a incredulidade, começando já pelo mistério que envolveu sua publicação. Swift preferiu proteger-se sob um pseudônimo durante as negociações com Benjamin Motte, o editor. Pope lhe contaria que "Motte recebeu a cópia (segundo me disse) sem saber de onde nem de quem, entregue em sua casa no escuro, por um coche; calculando o tempo, verifico que foi depois que você deixou a Inglaterra”118. A cópia das Viagens foi acompanhada por uma carta de "Richard Sympson”, escrita, por precaução, na caligrafia de Gay. Sympson declarava que seu primo, o capitão Lemuel Gulliver, lhe confiara havia anos o relato de suas viagens, que ele convenientemente abreviara para levar a público, desde que um editor assaz disposto o aceitasse. Motte aceitou o manuscrito, e a primeira edição saiu com um prefácio de Sympson comunicando ao leitor a proveniência do texto e esboçando a vida do “autor”. Lemuel Gulliver seria natural da cidade puritana de Banbury, onde havia de fato uma família com esse nome. Em 1728, por exemplo, foi sepultado no cemitério local um Samuel Gulliver, e até hoje várias lápides mantêm legível o nome da família ${ }^{119}$.

As Viagens, até prova em contrário, eram obra portanto de um viajante real, que naquela época vivia recolhido próximo a Newark. Na "Carta do Capitão Gulliver a seu primo Sympson”, incluída na edição de 1735, sabemos também que esse viajante era primo de William Dampier, o celebrado corsário cuja New Voyage Round the World (1697) foi em seu tempo o mais célebre de todos os relatos de viagens. Gulliver era ademais conhecido por seu amor à verdade: em Redriff, onde vivera muitos anos, tornara-se proverbial dizer que algo era “tão verdadeiro como se o Sr. Gulliver o houvesse dito" ${ }^{120}$. Cioso dessa reputação, ele próprio afirmará mais de uma vez seu compromisso com a verdade:

\footnotetext{
118 “Motte receiv'd the copy (he tells me) he knew not from whence, nor from whom, dropp'd at his house in the dark, from a Hackney-coach: by computing the time, I found it was after you left England.” Carta da Swift em 16 de novembro de 1726, in GT, p. 266.

${ }^{119}$ Cf. Turner (ed.), Gulliver's Travels, p. 291.

120 “it was as true as if Mr. Gulliver had spoke it”. “The Publisher to the Reader.” GT, p. 5.
} 
Eu talvez pudesse, como outros, ter-te assombrado com estórias estranhas e improváveis; mas preferi relatar fatos corriqueiros, na maneira e no estilo mais simples, porquanto meu propósito não era te divertir, mas informar-te. ${ }^{121}$

A preocupação com a plausibilidade não se revela somente em testemunhos diretos. O livro está repleto de artifícios autenticadores. O mais evidente deles é a profusão de detalhes. Gulliver é um narrador metódico que despeja sobre o leitor toda sorte de minúcias, presumivelmente extraídas de seu diário de viagens ${ }^{122}$. Sabemos, por exemplo, que na primeira viagem ele partiu de Bristol em 4 de maio de 1699; recebemos pormenores sobre os ventos, sobre as distâncias percorridas, sobre a latitude (a longitude ainda não era medida com precisão nessa época); sabemos quando Gulliver voltou e onde desembarcou. E tudo isso se repete nas demais viagens. Para tornar o estilo de Gulliver mais compatível com o de um homem de sua condição, Swift recorreu a uma linguagem sem adornos, e chegou a plagiar toda uma página da Mariner’s Magazine, usando e abusando da terminologia náutica ${ }^{123}$. O livro além disso é rico em descrições pormenorizadas e catálogos de objetos, em ocorrências banais e observações sem conseqüência.

Esses detalhes são em grande parte desnecessários ao desenrolar da ação, mas é justamente nisso que consiste sua serventia. A inclusão de minúcias secundárias tinha um efeito de que os escritores do século XVIII estavam bem cientes:

Como se avirá então [o narrador] para enganar-vos? Eis como: ele cumulará seu relato de pequenas circunstâncias tão ligadas ao tema, de traços tão simples, tão naturais e todavia tão difíceis de imaginar, que sereis forçado a dizer convosco: Por fé que isso é verdade; não se

\footnotetext{
121 "I could, perhaps, like others, have astonished thee with strange improbable tales; but I rather chose to relate plain matter of fact, in the simplest manner and style; because my principal design was to inform, and not to amuse thee.” In GT, IV, xii, 245.

${ }^{122}$ O diário não ocupa, como em Robinson Crusoé, uma posição muito visível no livro de Swift; mas Gulliver o considera, ao lado da boa memória, o requisito indispensável para escrever nesse gênero. Seu diário é mencionado três vezes. Ver GT, I, ii, p. 31; IV, iii, p. 198; e IV, xii, p. 246.

${ }^{123}$ Trata-se do segundo parágrafo da viagem a Brobdingnag.
} 
inventa esse tipo de coisa. ${ }^{124}$

O efeito que Diderot descreve pode ser ilustrado por um excerto de um dos escritores que melhor souberam empregá-lo. O narrador neste caso é um soldado inglês em Paris, e recebe de um pajem desconhecido a notícia de que seu capitão o chama. Ele é conduzido a um aposento escuro onde três homens lutam, e no calor da refrega acaba matando um deles.

A surpresa do fato, e o inesperado abate do homem por um desconhecido que surgira ninguém sabia como, apaziguou os outros dois, que me encaravam atônitos. Por essa altura eu já constatara que meu capitão não estava ali, e que algum estranho acidente me trouxera ao local. Eu falava mal o francês, e supunha que eles não falassem inglês. Por isso voltei-me em direção à porta, procurando o pajem que ali me conduzira; mas não avistando ninguém e estando a passagem livre, fugi o mais rápido que pude, sem dizer palavra. Tampouco os dois cavalheiros fizeram menção de deter-me.

O leitor naturalmente gostaria de saber quem era o pajem, com que propósito iludiu o narrador e que conseqüências teve o homicídio. Mas em vão: após duas páginas o incidente é esquecido, para não ser mais mencionado. A conclusão é que, se o episódio fosse fictício, o narrador cuidaria de arredondá-lo ou de vinculá-lo mais organicamente à narrativa; da maneira como está, ele só pode ser verdadeiro. Uma conclusão natural: o excerto pertence às Memoirs of a Cavalier (1720), de Defoe, livro que por mais de 60 anos foi aceito como uma autobiografia genuína datada do século XVII ${ }^{125}$.

Em Gulliver não há exemplos tão drásticos de pormenores dispensáveis, mas por toda

\footnotetext{
124 “Comment s’y prendra donc [le conteur] pour vous tromper? Le voici: il parsèmera son récit de petites circonstances si liées à la chose, de traits si simples, si naturels, et toutefois si difficiles à imaginer, que vous serez forcé de vous dire en vous-même: Ma foi, cela est vrai; on n'invente pas ces choses-là.” Diderot, Les Deux Amis de Bourbonne, p. 47.

125 "The Novelty of the Adventure, and the unexpected Fall of the Man by a Stranger come in no Body knew how, had becalmed the other two, that they really stood gazing at me. By this Time I had discovered that my Captain was not there, and that 'twas some strange Accident brought me thither. I could speak but little French, and supposed they could speak no English; so I stepped to the Door to see for the Page that brought me thither: but seeing no body there, and the Passage clear, I made off as fast as I could, without speaking a Word; nor did the other two Gentlemen offer to stop me.” Defoe, Memoirs of a Cavalier, p. 17.
} 
parte o detalhe menor se imiscui:

Propus deixar meus bens sob custódia como pagamento pelo frete: mas o capitão protestou que não receberia um tostão. Despedimo-nos cordialmente, e consegui que ele prometesse visitarme em minha casa em Redriff. Contratei um guia com cavalo por cinco xelins, que tomei emprestados do capitão. ${ }^{126}$

O leitor passaria bem sem saber quanto cobrava o guia e por que meios Gulliver conseguiu o dinheiro; tampouco lhe diz respeito a promessa do capitão, que jamais será cumprida. Mas a cena perderia em vividez se tais detalhes fossem suprimidos: são eles que a colorem e a tornam crível, tão crível quanto um relato veraz. "Mesmo Robinson Crusoé (embora relatando eventos muito mais prováveis) dificilmente supera Gulliver em seriedade e verossimilhança narrativa”, observaria Sir Walter Scott ${ }^{127}$.

Além do detalhismo, a narrativa de Gulliver comporta outros artifícios autenticadores. Em mais de um momento a estória estabelece vínculos com o mundo real. Os nomes dos navios em que Gulliver parte — Swallow, Adventure, Hopewell — eram todos de navios verdadeiros. As terras descritas situam-se em regiões convenientemente afastadas mas muito reais, e em geral Gulliver se preocupa em explicar por que elas eram desconhecidas na Europa. Brobdingnag, por exemplo, não fora antes tocada pelos europeus por ser uma península isolada por vulcões altíssimos e mares bravios;

donde não posso senão concluir que nossos geógrafos na Europa muito se enganam ao supor que nada há salvo o mar entre o Japão e a Califórnia; pois sempre fui de opinião que cumpre haver um balanço de terra como contrapeso ao grande continente da Tartária. Eles deveriam por conseguinte corrigir seus mapas e cartas, unindo essa vasta faixa de terra à parte noroeste da

\footnotetext{
126 "I offered to leave my Goods in Security for Payment of my Freight: but the Captain protested he would not receive one Farthing. We took kind leave of each other, and I made him promise he would come to see me at my House in Redriff. I hired a Horse and Guide for five Shillings, which I borrowed of the Captain.” GT, II, viii, p. 124.

127 "Even Robinson Crusoe (though detailing events so much more probable,) hardly excels Gulliver in gravity and verisimilitude of narrative.” Scott, Life of Swift. In TCH, p. 293.
} 
América, para o que me predisponho a prestar-lhes assistência. ${ }^{128}$

A proposta se assemelha às sugestões que Dampier fizera aos hidrógrafos para corrigir a extensão dos Oceanos Índico e Atlântico ${ }^{129}$, e constitui um traço usual dos relatos de viagens reais.

Outro fator que contribui para a verossimilhança é a consistência dos mundos visitados. Uma vez ditadas as regras desses mundos, elas são observadas com razoável rigor. Em Lilliput e Brobdingnag as proporções entre o protagonista e os nativos estão o tempo todo em evidência. Os gigantes de Rabelais, por exemplo, só são gigantes quando convém à sátira; em outros momentos seu gigantismo é convenientemente esquecido. Não se explica, por exemplo, como Pantagruel flertava com as moças ou visitava o interior das universidades européias. Mas ficamos sabendo como Gulliver se alimentava, como conseguia roupas, como se abrigava dos elementos, como via e julgava seres e objetos tão maiores ou tão menores que ele, e como estes o viam e julgavam. E a consistência não se limita a questões de proporção. Os acontecimentos têm uma coerência muito rara nesse gênero. Quando Gulliver avança em missão militar contra o império de Blefuscu (I, v), ele protege os olhos das setas inimigas com um par de óculos que trazia ao bolso; longe de constituir um improviso, esse par de óculos é o mesmo que havia anteriormente escapado à vistoria dos liliputianos (I, ii). Se demonstra ao imperador o uso da pólvora (I, ii), Gulliver também se preocupa em explicar como ela não se molhou no naufrágio. Se os Houyhnhnms têm enigmáticos artigos manufaturados — como casas e coches puxados por Yahoos —, ficamos sabendo que eles são habilíssimos com seus cascos, chegando à façanha de passar um fio pelo buraco da agulha $(\mathrm{IV}, \mathrm{ix})^{130}$.

Por fim, Gulliver procura conquistar a cumplicidade do leitor demonstrando ele próprio uma ocasional surpresa. Eis sua reação ao ser albergado entre os Houyhnhnms:

\footnotetext{
128 “whence I cannot but conclude, that our Geographers of Europe are in a great Error, by supposing nothing but Sea between Japan and California; for it was ever my Opinion, that there must be a Balance of Earth to counterpoise the great Continent of Tartary; and therefore they ought to correct their Maps and Charts, by joining this vast Tract of Land to the North-west parts of America, wherein I shall be ready to lend them my Assistance.” GT, II, iv, p. 92.

${ }^{129}$ Dampier, A New Voyage Round the World, X, pp. 196-201.
} 
Receei que meu cérebro houvesse sido perturbado por meus sofrimentos e infortúnios. Levanteime e observei o aposento onde fora deixado só: era mobiliado como o primeiro, salvo que de maneira mais elegante. Esfreguei os olhos mais de uma vez, mas os mesmos objetos se me apresentavam. Belisquei os braços e os flancos para acordar, na esperança de estar num sonho. $^{131}$

Mais adiante, quando Gulliver adquire rudimentos da linguagem e começa a contar sua história ao mestre Houyhnhnm (IV, iii), este duvida que possa haver um outro país além dos mares. O leitor inglês, que tem sua própria existência posta em dúvida, é obrigado a censurar o ceticismo desinformado. Com essa hábil manobra, o narrador o predispõe à credulidade. Para os céticos obstinados ele só teria desprezo:

Se a censura dos Yahoos pudesse de algum modo afetar-me, eu teria grande motivo de queixa, já que alguns deles têm a audácia de considerar meu livro de viagens uma mera ficção nascida de meu cérebro, e chegam ao ponto de insinuar que os Houyhnhnms e Yahoos não têm mais existência do que os habitantes de Utopia. ${ }^{132}$

Gulliver, em suma, é um narrador extremamente cioso da veracidade, e procura credenciar o relato de suas viagens com uma vasta gama de artifícios autenticadores. À pergunta de nosso leitor hipotético _ “ “Isso tudo é verdade?” — podemos oferecer esta resposta parcial: Gulliver faz o possível para que pareça verdade.

\footnotetext{
${ }^{130}$ Não se sabe como Swift pretendia que fosse pronunciado o nome dos cavalos, mas tornou-se convencional a pronúncia whinnim, o que remete ao verbo to whinny ("relinchar").

131 "I feared my Brain was disturbed by my Sufferings and Misfortunes. I roused my self, and looked about me in the Room where I was left alone: this was furnished like the first, only after a more elegant manner. I rubbed my Eyes often, but the same Objects still occurred. I pinched my Arms and Sides to awake myself, hoping I might be in a Dream.” GT, IV, ii, p. 194.

132 "If the Censure of the Yahoos could any way affect me, I should have great Reason to complain, that some of them are so bold as to think my Book of Travels a mere Fiction out of mine own Brain, and have gone so far as to drop Hints, that the Houyhnhnms and Yahoos have no more Existence than the Inhabitants of Utopia. GT, "A Letter from Capt. Gulliver, to his Cousin Sympson”, p. 256.
} 
Ao que o leitor fatalmente replicará: "E todavia ele mente!”.

\subsubsection{Viagens imaginárias}

Um elemento fundamental de As Viagens de Gulliver é a incompatibilidade entre o arcabouço realista da narrativa e o conteúdo que esse arcabouço se presta a transmitir. De um lado temos a proveniência atestada do manuscrito, as profissões de veracidade, a riqueza de detalhes secundários, a precisão temporal e geográfica e a coerência interna; de outro, temos homens de seis polegadas ou sessenta pés de altura, uma ilha voadora, uma raça de imortais, cavalos falantes e outros “fatos corriqueiros”. Não há dúvida: estamos na província da viagem imaginária.

Em sua tentativa de classificar Gulliver dentro desse subgênero, William A. Eddy dividiu as viagens imaginárias entre românticas e filosóficas; as viagens filosóficas, por sua vez, foram subdivididas em fantásticas e realistas. Nessa classificação As Viagens de Gulliver ocupam um lugar ambíguo, pois embora sejam em substância fantásticas, sua forma narrativa é realista — "o tipo de narrativa de uma viagem real, caracterizada pelas experiências comuns e invariáveis do marujo ordinário"133. Num salto de imaginação, é como se tivéssemos as viagens de Simbá narradas por William Dampier ${ }^{134}$.

Que Swift tenha optado pelo subgênero da viagem imaginária é, como vimos, compreensível. O artifício estava previsto no projeto das Memoirs of Martinus Scriblerus. Ademais, as vantagens desse gênero para o comentário político e cultural eram evidentes. A viagem imaginária como mecanismo satírico já era conhecida desde os tempos de Luciano de Samósata, cuja História Verdadeira procurava ridicularizar relatos falsificadores como os de Ctésias, Heródoto ou até mesmo Ulisses. Ela passara por Rabelais e Cyrano de Bergerac, e

\footnotetext{
133 "the type of narrative of actual travel, distinguished by the standard, invariable experiences of an ordinary seaman”. Eddy, Gulliver's Travels: A Critical Study, p. 29.

${ }^{134}$ Por falar em Simbá, embora admita-se uma certa influência geral das Mil e Uma Noites sobre Swift, há uma possível influência particular que ainda não vi apontada por nenhum crítico. A história da mulher que desdenhou o primeiro-ministro de Laputa para viver com um lacaio que a maltratava pode ter sido inspirada num episódio das Noites na versão de Galland. Ver a “Histoire du Jeune Roi des Îles”, em Les Mille et Une Nuits, p. 64.
} 
vinha tendo uma voga crescente nos séculos XVII e XVIII ${ }^{135}$. Sucessos como O Espião nas Cortes dos Reis Cristãos (1684), do genovês Gian-Paolo Marana, e as Cartas Persas (1721), de Montesquieu, ilustrariam bem a eficácia do método - que consistia basicamente em submeter a realidade a um olhar estranho, exaltando-lhe os absurdos. O sucesso de Cyrano, particularmente, ajudou a ampliar o escopo da viagem imaginária para além dos confins da utopia. Depois da época de More o interesse narrativo desse gênero passou a disputar terreno com a mensagem filosófica. Uma espécie de propósito ulterior se preservou em muitos casos, mas a utopia genuína se tornou rara e perdeu-se em elementos ambíguos e trechos distópicos - como em The Isle of Pines (1668), de Henry Neville ${ }^{136}$. No início do século XVIII a viagem imaginária deixara de ser um mero enquadramento para o diálogo filosófico (como em More e Campanella) e se tornara efetivamente uma estória. Sua finalidade predominante seria a sátira, e nisso consistia seu atrativo para Swift. Em abril de 1711 ele mencionou a Stella uma sugestão que dera a Steele para um número do Spectator, "sobre um indiano que supostamente escreveria suas viagens à Inglaterra. Lamento que ele a tenha tido. Eu pretendia escrever um livro sobre o assunto" ${ }^{\prime 137}$. Em Gulliver Swift inverteria o enfoque, enviando um inglês a países estranhos que, não obstante, representam em muitos sentidos sua terra natal. A pílula da sátira seria adocicada pela riqueza ficcional que nessa época caracterizava o gênero; e a ficção, como em Luciano ou Rabelais, se justificaria por estar a serviço da sátira.

Mas por que asseverar a veracidade de uma narrativa tão evidentemente falaciosa? Luciano, por exemplo, após denunciar os falsificadores de relatos, declara: "Minha maneira de mentir é muito mais honesta que a deles; pois há pelo menos um ponto em que serei

\footnotetext{
135 Confira-se o abrangente estudo de Philip Babcock Gove, The Imaginary Voyage in Prose Fiction, que enumera 215 viagens imaginárias publicadas entre 1700 e 1800. Minhas observações sobre o desenvolvimento do gênero nessa época baseiam-se em Ralph E. Tieje, The Prose Imaginary Voyage before 1900 (1917), que Gove resume nas páginas 92-96. Aos interessados é útil saber que o livro de Gove inclui longas citações não traduzidas em francês, alemão e holandês, além de passagens mais breves em outros idiomas, o que pode limitar sua utilidade.

${ }^{136}$ O texto de Neville vem atraindo interesse por prenunciar certos elementos de Robinson Crusoé. Cumpre advertir, porém, que sua versão mais comum (incluída por Philip Henderson em Shorter Novels: Seventeenth Century) elimina as ambigüidades de sentido ao suprimir a importante “Carta de Van Sloetten”, que emoldura a narrativa de Pines. A versão completa foi incluída por Susan Bruce em Three Early Modern Utopias (ver bibliografia).

${ }^{137}$ The Journal to Stella, XXI, 28 de abril de 1711. O texto de Steele saiu no Spectator $\mathrm{N}^{\circ} 50$.
} 
verídico, e é em reconhecer que sou mentiroso”"138. Já Gulliver faz precisamente o contrário, embora suas chances de iludir o leitor não sejam maiores que as de Luciano. As razões para sua atitude são sugeridas na terceira parte, quando ele conferencia com figuras da Antigüidade:

Ali descobri a velhacaria e ignorância dos que pretendem escrever anedotas, ou histórias secretas; que remetem tantos reis ao túmulo com um cálice de veneno; que repetem discursos entre um príncipe e um primeiro-ministro, quando não havia testemunhas; que descerram os pensamentos e gabinetes de embaixadores e secretários de Estado; e que têm o perpétuo infortúnio de estar equivocados. ${ }^{139}$

Este é um dos momentos em que a voz de Gulliver deixa de ser a do cirurgião e marujo e se confunde com a do homem de letras que o imagina. Swift via com desconfiança e aversão o gênero das histórias secretas, com suas descrições pseudoverazes de eventos absolutamente imaginários - eventos que acabavam, não obstante, se imiscuindo nas páginas da história. A ambigüidade entre fato e ficção não era apanágio das histórias secretas: era comum em muitas outras formas, como por exemplo os falsos relatos de viagens a terras remotas. Motivados pelo sucesso de autores como Dampier, muitos escritores passaram a satisfazer a curiosidade pública descrevendo a fauna, a flora, os povos e os costumes de países distantes sem o inconveniente de visitá-los. A desconfiança com relação a esse ardil atingiu um pico em 1704, quando foi desmascarado o então famoso George Psalmanazar, um francês que se passava por formosino e que publicou em Londres uma detalhada descrição de Formosa, jactando-se de sua veracidade ${ }^{140}$. Os scriblerianos tinham um olho nessa tendência, e as viagens de Martinus destinavam-se em parte a atacá-las (“Que outros mortais se debrucem sobre mapas e engulam

\footnotetext{
138 "Ma manière de mentir est beaucoup plus honnête que la leur; car il y a du moins un point où je serai véridique, c’est en avouant que je suis un menteur.” Luciano de Samósata, Histoire Vraie (versão francesa de Émile Chambry), p. 32.

${ }^{139}$ Here I discovered the Roguery and Ignorance of those who pretend to write Anecdotes, or secret History; who send so many Kings to their Graves with a Cup of Poison; will repeat the discourse between a Prince and Chief Minister, where no Witness was by; unlock the thoughts and cabinets of Ambassadors and Secretaries of State; and have the perpetual Misfortune to be mistaken.” GT, III, viii, p. 170.
}

${ }^{140}$ An Historical and Geographical Description of Formosa, an Island Subject to the Emperor of Japan (1704). 
as lendas de viajantes mentirosos”141). Enquanto redigia Gulliver, Swift se ocupou com a leitura de relatos de viagens ${ }^{142}$, entre os quais talvez estivesse Robinson Crusoé considerado por seu “editor” uma “justa história de fatos; tampouco há nela qualquer aparência de ficção” 143 . Por essa época já se sabia que Robinson Crusoé era, sim, ficção, e muitas das outras viagens lidas por Swift deviam ser igualmente imposturas. Ele recorreria a um método sutil para desmascará-las — o mesmo método que já empregara em mais de uma sátira: adotar a voz de seu adversário para proferir absurdos.

Ao contrapor o realismo dos relatos de viagens às aventuras absolutamente improváveis de Gulliver, Swift está exaltando o caráter enganoso daquele. Como ele demonstra, as convenções realistas podem perfeitamente ser postas a serviço da falsidade. Exemplos disso abundam nas Viagens. Num certo momento (I, viii), Gulliver relata suas experiências em Lilliput aos marinheiros que o resgatam, e como prova de sua veracidade tira dos bolsos minúsculos bois e carneiros. Nessa passagem Paul Turner incluiu a seguinte nota:

como o leitor não pode ver os carneiros e bois, essa prova de veracidade é equivalente à de Luciano quando, após relatar as mais desvairadas estórias sobre a sociedade lunar, ele conclui: “Bem, assim eram as coisas na Lua. Se você não acredita, vá e veja com seus próprios olhos”. ${ }^{144}$

Mais adiante (II, iii) Gulliver oferece uma prova mais palpável de suas viagens, declarando haver exposto em vários lugares da Europa os ferrões das vespas gigantes que matara em Brobdingnag; quem os quisesse ver podia procurá-los no Gresham College, sede da Real Sociedade. (E fatalmente os veria, pois lá se encontravam reproduções ampliadas de muitos insetos — interesse que Swift julgava dos mais fúteis.) Lembremo-nos ainda da seriedade com que Gulliver refuta os boatos de que tivera um caso com a esposa de Flimnap, o

\footnotetext{
141 “Let other Mortals pore upon Maps, and swallow the legends of lying travellers.” MMS, II, p. 101.

${ }^{142}$ Ver carta a Vanessa em 13 de julho de 1722.

143 Defoe, Robinson Crusoé, “Preface”, p. 3.

144 "since the reader cannot see the sheep and cattle, this proof of veracity is equivalent to Lucian's when, after telling some very tall stories about lunar society, he concludes: 'Well, that is what it was like on the Moon. If you don’t believe me, go and see for yourself’.” Turner (ed.), Gulliver’s Travels, p. 307.
} 
tesoureiro de Lilliput. “Admito que ela vinha amiúde à minha casa, mas sempre publicamente, e nunca sem outras três pessoas no coche, que eram de uso sua irmã e sua jovem filha, além de algum amigo próximo.”145 Essa circunspecção denota franqueza, mas omite o fato elementar de que a Sra. Flimnap tinha seis polegadas de altura. Em todos esses casos o aparente apego de Gulliver pela verdade é acompanhado pela exposição inadvertida de absurdos. Também pode ser acompanhado pela mais pura irrelevância. A Real Sociedade havia exortado os viajantes a ser muito minuciosos no registro de dados. Foi isso que motivou a precisão do relato de Dampier, por exemplo. Gulliver, seguindo o mesmo conselho, é devotamente meticuloso:

Ocultei-me entre duas folhas de azeda, e ali aliviei as necessidades da natureza.

Espero que o gentil leitor me perdoe por alongar-me neste e em outros detalhes do tipo, que, por insignificantes que pareçam a mentes vulgares e chãs, certamente ajudarão o filósofo a alargar seus pensamentos e sua imaginação e a aplicá-los no benefício da vida pública e privada. ${ }^{146}$

Ao longo das Viagens o conflito entre o conteúdo e as convenções realistas sugere que artifícios como o manuscrito original, o “autor” recolhido, a profusão de detalhes e os vínculos com o mundo real não eram garantia alguma de veracidade ou valor documental. Eles constituíam antes um disfarce para que a ficção tentasse invadir o nobre terreno da história. Essa é uma infração que Swift via como grave, e que As Viagens de Gulliver em momento algum cometem. O livro, apesar dos artifícios autenticadores, assume de diversas maneiras seu caráter ficcional. A mais evidente é o conteúdo extravagante, mas há outras. Fica claro, pelas passagens acima, que a voz do narrador é amiúde desacreditada pela ironia de fundo. E Swift procurou confirmar por outros meios a distância entre criador e criatura.

\footnotetext{
145 "I own she came often to my House, but always publicly, nor ever without three more in the Coach, who were usually her Sister and young Daughter, and some particular Acquaintance.” GT, I, vi, p. 54.

146 "I hid my self between two Leaves of Sorrel, and there discharged the Necessities of Nature./I hope the gentle Reader will excuse me for dwelling on these and the like Particulars, which, however insignificant they may appear to groveling vulgar Minds, yet will certainly help a Philosopher to enlarge his Thoughts and Imagination, and apply them to the Benefit of Public as well as private Life.” GT, II, i, p. 78.
} 
More, na composição de seu livro, procurara deixar indícios "que habilitassem aos mais cultos enxergarem através do véu do simulacro"147; em Utopia temos um rio Anidro (“sem água”), um rei Ademos (“sem povo”) e o relator Hitlodeu (“mercador de disparates”). Swift fez algo muito similar. O nome Gulliver (que só aparece no frontispício, não ocorrendo nenhuma vez no texto) pode significar simplesmente gullible (“crédulo”, “simplório”) ${ }^{148}$. Para reforçar a sugestão, a edição de 1735 trouxe um retrato imaginário de Gulliver ornado pela inscrição “Splendide Mendax” (“mentiroso esplêndido”). A expressão provém de uma ode de Horácio em que uma mulher comete perjúrio para evitar que seu pai lhe mate o marido. A mentira, nesse contexto, se torna uma forma de retidão, e "ressuscita a complexa confiabilidade moral de Gulliver, no momento mesmo em que desabona sua veracidade narrativa”149. Em outras palavras, as mentiras de Gulliver podem ser o veículo para a transmissão de verdades mais amplas.

\subsubsection{O viajante imaginário}

Quando Swift entra em campo para combater os viajantes de sótão que se pretendiam verazes, ele se empenha também em refutar sua visão progressista de mundo. Para o primeiro objetivo, ele tomou emprestada a mesma postura epistemológica que pretendia desmentir. Para o segundo, ele recorre ao mesmo herói que tenciona desvirtuar. Desde os primeiros parágrafos ficamos sabendo que Gulliver é o terceiro filho de uma família modesta de extração puritana, e que seu histórico é o do homem de classe média. Uma possibilidade que já ocorreu à crítica é a de que a abertura autobiográfica seja uma alegoria da carreira de Defoe $^{150}$. É certo que Gulliver, em sua busca pela prosperidade nos mares, remete inicialmente a Robinson Crusoé. Num sentido mais amplo, ele remete também a outros narradores autobiográficos por cuja consciência individual o mundo se refletia. Vale lembrar

\footnotetext{
${ }^{147}$ More, em carta a Peter Giles, Utopia, p. 187.

${ }^{148}$ Gullible nessa época seria um neologismo criado a partir do verbo to gull. A palavra só surge de fato no século XIX. Cf. A. D. Nuttall, “Gulliver among the horses”, in Rawson (ed.), Jonathan Swift: A Collection of Critical Essays, p. 256.

149 “resurrects Gulliver’s complicated moral reliability even as it impeaches his narrative veracity.” Janine Barchas, “The Paratext of The Travels: Gulliver’s Many Faces”. In GT, p. 476.

150 John Robert Moore, “A DeFoe Allusion in Gulliver's Travels”. Cf. Hunter, “Gulliver's Travels and the novel”, in GGT, p. 74 .
} 
que a narrativa em primeira pessoa era o artifício mais conveniente para o autor que desejasse afirmar a autenticidade de seu relato. Por meio dela era possível invocar a convenção do manuscrito autobiográfico ou do diário de bordo. O enredo básico desse tipo de narrativa consistia num tortuoso caminho rumo à prosperidade ou à remissão; o “autobiógrafo”, que escrevia tempos depois dos eventos narrados, e a quem a experiência trouxera sabedoria, podia julgar moralmente o passado, condenando ou aprovando como melhor lhe conviesse. Essa visão retrospectiva e esclarecida constituía um eficiente filtro ideológico. Robinson Crusoé era uma espécie de “diário das virtudes mercantis”"151 — esse tipo de virtude que McKeon associou à ideologia progressista. Em Gulliver, porém, a fidelidade a esse modelo é apenas aparente. A promessa implícita na abertura — de um retorno triunfante após várias peripécias - não se cumpre. O narrador é muito ineficaz como herói progressista, fracassando não somente no requisito do progresso, mas também no do julgamento retrospectivo.

Em primeiro lugar, Gulliver não prospera e não aprende. Na abertura da quarta viagem, após tanto tempo como cirurgião de bordo, ele finalmente recebe a proposta de ser capitão de um navio, mas o sucesso não dura duas páginas: um motim o destitui da posição e ele é abandonado em desgraça no país dos Houyhnhnms. Não somente sua condição não melhora, como seu espírito até esse momento não guarda marcas da experiência. As viagens se sucedem sem que haja um verdadeiro movimento no tempo ${ }^{152}$. Embora o caráter do narrador sofra trancos (veja-se mais abaixo), após cada retorno voltamos a encontrar na abertura seguinte o mesmo Gulliver, "condenado pela natureza e fortuna a uma vida ativa e irrequieta”"153.

"Permaneci em casa com minha esposa e meus filhos por cerca de cinco meses, numa condição das mais felizes, se eu pudesse ter aprendido a lição de perceber quando estava bem.”154

\footnotetext{
151 Título de um ensaio que Italo Calvino dedicou a Defoe, em Por que ler os clássicos.

${ }^{152}$ A esse respeito, cf. Ehrenpreis, “Show and Tell in Gulliver's Travels”, in GT, pp. 450-467.

153 “condemned by Nature and Fortune to an active and restless Life”. GT, II, i, p. 69.

154 "I continued at home with my Wife and Children about five Months, in a very happy Condition, if I could have learned the Lesson of knowing when I was well.” GT, IV, i, p. 187.
} 
O movimento do livro é, enfim, cíclico. Procuraremos em vão, na viagem a Laputa, indícios de que o narrador já passou por Lilliput e Brobdingnag. Somente o livro II guarda reminiscências claras de fatos anteriores, necessárias neste caso ao efeito satírico. Se em Lilliput o leitor vê que o orgulho e a ambição podem brotar em criaturas desprezíveis, em Brobdingnag ele é subitamente posto no papel dessas criaturas. A conclusão é que tudo o que vale contra os liliputianos vale igualmente contra os europeus. A lição, se se imprime no leitor, não o faz todavia em Gulliver: este é justamente o livro em que seus elogios à pátria são os mais desmedidos. A experiência em Lilliput não serviu de nada para seu engrandecimento de espírito. É apenas na quarta viagem que testemunhamos uma verdadeira renovação pessoal, e não se trata da típica remissão moral de tantas narrativas da época. O personagem que deveria encerrar suas andanças num estado de maior discernimento só degenera em misantropia. O esperado elogio às virtudes do homem que percorre o mundo e domestica a natureza não se concretiza, e em seu lugar temos uma declaração de ódio à humanidade. Igualmente ausente é o entusiasmo mercantil. Dampier, por exemplo, recomenda repetidamente o fortalecimento mundial do comércio inglês, e só tem olhos para o intercâmbio de bens: mesmo os animais e as plantas interessam-lhe como mercadorias. Em Gulliver inexistem as costumeiras sugestões de expedições exploratórias ao governo. O livro se encerra com um manifesto contra o colonialismo, especificamente contra o tratamento dispensado pela Inglaterra à Irlanda. O comércio e a prosperidade a ele associada só figuram no livro em cores negativas.

Em segundo lugar, a visão retrospectiva é muito problemática no caso de Gulliver. Nas autobiografias ficcionais da época o protagonista costuma estar presente de duas maneiras simultâneas: como o jovem estouvado que age e como o homem ponderado que narra, e é da interação entre as ações do primeiro e o julgamento do segundo que resulta o significado moral da obra. Nas Viagens tal interação raramente ocorre. O relato foi escrito cinco anos após o retorno definitivo de Gulliver à Inglaterra (IV, xi). Nessa época ele já era o misantropo que havia deixado a contragosto o país dos Houyhnhnms e que só com dificuldade tolerava a vizinhança das pessoas. No entanto, sem consultarmos o livro IV ou as cartas de Gulliver, jamais suspeitaríamos que os livros I-III foram escritos por um misantropo. O tom é incompatível com o caráter final do narrador. O velho Gulliver jamais escreveria um trecho 
como este, em que o rei de Brobdingnag acaba de cobrir os ingleses de reprimendas:

\begin{abstract}
Nada, salvo um extremo amor pela verdade, poderia ter-me impedido de omitir esta parte de minha estória. Seria vão demonstrar meus ressentimentos, que eram sempre convertidos em ridículo; e fui forçado a agüentar com paciência enquanto meu nobre e amado país era tratado tão injuriosamente. ${ }^{155}$
\end{abstract}

Falta aqui o proverbial “eu era jovem e não sabia”. Sentimos a mesma ausência de julgamento retrospectivo até meados do livro IV, quando a transformação moral de Gulliver tem início. Isso ocorre porque Gulliver não descreve os acontecimentos como os vê em sua posição de memorialista, mas como os vira no momento em que eles tinham lugar. Os julgamentos e as ações pertencem quase sempre ao mesmo Gulliver — o Gulliver do passado. Não temos com isso um narrador que, como bom herói progressista, reconsidere seus atos à luz da experiência adquirida. Mesmo que seu estado final não fosse a misantropia, ele seria incapaz de extrair um corolário ideológico das atribulações que descreve. Há basicamente duas razões para esse problema de ponto de vista. A primeira é a estrutura episódica do livro: as quatro viagens são quase que unidades autônomas, e quando Swift concebeu as primeiras ele provavelmente não pensara ainda no desfecho da quarta. A segunda razão é que a idéia de consciência individual era vista com aversão por Swift e por muitos augustanos, para quem

tentativas de ler o mundo e seu propósito mediante o registro de impressões sensórias e a atribuição de qualidades simbólicas a coisas e eventos (como ocorre em Robinson Crusoé e na tradição emblemática representada por meditadores meletéticos como Robert Boyle) [são] enfim um modo arrogante, interesseiro e até mesmo solipsista de encarar o mundo. ${ }^{156}$

\footnotetext{
155 "Nothing but an extreme Love of Truth could have hindered me from concealing this Part of my Story. It was in vain to discover my Resentments, which were always turned into Ridicule; and I was forced to rest with Patience, while my noble and beloved Country was so injuriously treated.” GT, II, vii, p. 111.

156 "attempts to read the world and its purpose through the recording of sense impressions and the imparting of symbolic qualities to things and events (as done in Robinson Crusoe and in the emblematic tradition represented by meletetic meditators like Robert Boyle) is [sic] finally an arrogant self-serving, even solipsistic way of regarding the world.” J. P. Hunter, “Gulliver's Travels and the Novel”, in GGT, p. 68.
} 
Acrescente-se ainda que o individualismo, para Swift, estava associado a seitas dissidentes de tendência calvinista, com sua ênfase na autonomia do intercurso entre Deus e o fiel e seu conseqüente descaso pela igreja estabelecida. Era, em suma, uma tendência rebelde e subversiva. Por tudo isso, Swift não se preocupou em adotar o modelo da consciência individual senão superficialmente, e como resultado seu narrador não pôde temperar o relato de acordo com suas idiossincrasias.

Isso não comprometeria necessariamente a coerência moral da narrativa: se o narrador é omisso, poderíamos perfeitamente nos contentar com os julgamentos do jovem Gulliver. Ocorre, porém, que Gulliver é inconsistente não apenas como narrador, mas também como protagonista. Observei mais acima que seu caráter não sofre uma evolução rumo a uma condição final. Resta dizer que tal “caráter” tampouco se preserva. A verdade é que Gulliver não possui estabilidade suficiente para que uma evolução seja discernível, nem para que lhe atribuamos uma personalidade fixa. Ele sofre modulações bruscas e freqüentes, para as quais não existe nenhuma causa externa visível. Num momento ele é o observador perspicaz que enxerga nitidamente a corrupção à sua volta; em outro, é um tolo que sem perceber elogia a mesma corrupção. Na mesma situação podemos vê-lo ora sensato, ora ingênuo, ora inadvertidamente irônico. Um exemplo é seu tratamento da justiça inglesa. Neste trecho ele a critica, comparando-a com a de Lilliput:

E essa gente considerou uma prodigiosa falha de política entre nós quando lhes contei que nossas leis eram impostas somente por penalidades, sem menção alguma de recompensas. É por esse motivo que a imagem da justiça, em suas cortes de judicatura, é formada com seis olhos, dois na frente, dois atrás e um de cada lado, para denotar circunspecção; e com um saco de ouro aberto na mão direita e uma espada embainhada na esquerda, para demonstrar que ela se dispõe mais a recompensar do que a punir. ${ }^{157}$

\footnotetext{
157 “And these People thought it a prodigious Defect of Policy among us, when I told them that our Laws were enforced only by Penalties, without any Mention of Reward. It is upon this account that the Image of Justice, in their Courts of Judicature, is formed with six Eyes, two before, as many behind, and on each Side one, to signify Circumspection; with a Bag of Gold open in her Right Hand, and a Sword sheathed in her Left, to show she is more disposed to reward than to punish.” GT, I, vi, p. 49.
} 
Mais adiante sua atitude crítica desaparece:

Passei então às cortes de justiça [inglesas], sobre as quais os juízes, esses veneráveis sábios e intérpretes da lei, presidiam, para determinar disputas sobre os direitos e propriedades dos homens, bem como sobre a punição do vício e a proteção da inocência. ${ }^{158}$

E em seguida dá lugar à ironia involuntária (o trecho a seguir pretende ser lisonjeiro):

Vossa Excelência ora há de saber que esses juízes são pessoas designadas para decidir quaisquer controvérsias relativas à propriedade e ao julgamento de criminosos, sendo escolhidos dentre os mais hábeis advogados, quando envelhecidos ou preguiçosos; e, por se haverem inclinado durante toda a vida contra a verdade e a eqüidade, sentem uma necessidade tão fatal de favorecer a fraude, o perjúrio e a opressão, que eu soube de alguns que recusaram grandes subornos do lado em que estava a justiça para não ofenderem sua profissão com atitudes incompatíveis com sua natureza ou seu ofício. ${ }^{159}$

As oscilações de caráter de Gulliver tornam complexo seu estatuto como personagem. Ele não é nem “plano” nem “redondo”, para usar os termos de Forster ${ }^{160}$ : não se limita a uma única idéia ou qualidade, nem envolve uma variedade delas. Ele é antes um complexo de características muitas vezes incompatíveis que se sucedem no tempo, sem a necessidade de influxos exteriores. Se o misantropo que rememora não é capaz de proporcionar ao leitor o

\footnotetext{
158 "I then descended to the Courts of Justice; over which the Judges, those venerable Sages and Interpreters of the Law, presided, for determining the disputed Rights and Properties of Men, as well as for the Punishment of Vice and Protection of Innocence.” GT, II, vi, p. 107.

159 "Now your Honour is to know, that these Judges are Persons appointed to decide all Controversies of Property, as well as for the Trial of Criminals, and picked out from the most dexterous Lawyers, who are grown old or lazy; and having been biassed all their Lives against Truth and Equity, lie under such a fatal Necessity of favouring Fraud, Perjury, and Oppression, that I have known some of them refuse a large Bribe from the Side where Justice lay, rather than injure the Faculty, by doing any Thing unbecoming their Nature or their Office.” GT, IV, v, p. 210.

${ }^{160}$ E. M. Forster, Aspects of the Novel, p. 73ss.
} 
tipo de orientação moral que as autobiografias tipicamente ofereciam, esse protagonista tão instável tampouco servirá de guia.

A biografia narrada em primeira pessoa por um herói esclarecido de classe média é, assim, uma convenção que Swift adota somente para subvertê-la. Não significa, porém, que os acontecimentos em Gulliver sejam isentos de um juízo direto - em outras palavras, que o livro “mostre” mas não “conte”"161. Ocorre apenas que esse juízo, que o narrador e o protagonista não conseguem nos oferecer, acaba provindo de outra direção. O significado dos eventos é sugerido por uma outra presença no texto — a mesma presença que nos permite saber que a narrativa é falsa, apesar das afirmações de Gulliver em contrário. Essa outra voz — cujo distanciamento de Gulliver varia e nem sempre é nítido — é a do satirista. Trata-se da única voz consistente no desenrolar das viagens, e a ela podem sacrificar-se outras considerações, como a coerência psicológica do narrador.

[Gulliver] fala como o faz não por ser tal e qual personagem, desenvolvendo-se ou modulando desta ou daquela maneira, e adotando tons de voz que respondam a mudanças e pressões em suas circunstâncias e seu temperamento, mas porque Swift o está usando para projetar propósitos satíricos mais amplos, numa manipulação da indireta irônica, e não do ponto de vista característico dos romances. ${ }^{162}$

A instabilidade do caráter de Gulliver se explica pela variedade de enfoques satíricos que Swift adotou, às vezes ridicularizando o mundo através da visão do narrador, e outras vezes ridicularizando o próprio narrador por sua falta de visão. “[Gulliver] é em grande medida o que quer que Swift deseje ou precise que ele seja a cada momento da narrativa; ele é mais uma figura retórica do que humana” ${ }^{\text {} 163}$. Gulliver constitui assim mais uma das personce de

\footnotetext{
161 Sobre a distinção usual entre "mostrar” e “contar”, cf. Wayne C. Booth, The Rhetoric of Fiction; Booth trata de Gulliver no capítulo 11 da parte III.

162 "He speaks as he does not because he is such and such a character, developing or modulating in this or that way, adopting tones of voice that respond to changes and to pressures in his circumstances or temperament, but because Swift is using him to project larger satiric purposes, in a manipulation of ironic indirection, not of novelistic point of view.” Claude Rawson, “Reflections on Swift's 'I’ Narrators”, in GT, p. 487.

163 "He is pretty much whatever Swift wants or needs him to be at any given point in the narration; he is more of a rhetorical figure than a human one.” J. P. Hunter, “Gulliver's Travels and the later writings”, in CCJS, p. 227.
} 
Swift, ao lado de Isaac Bickerstaff, do compilador do Conto do Tonel e do autor da Modesta Proposta. A lista é instrutiva: vemos nela um vidente que expõe ao ridículo a astrologia, um erudito cuja obra desqualifica a erudição e um proponente que faz lamentar a publicação de propostas. No caso de Gulliver, o que temos é um viajante imaginário sem sucesso e sem mensagem positiva - um herói das viagens progressistas que põe em descrédito as convenções dessas mesmas viagens.

\subsubsection{A alternativa conservadora}

A subversão dos métodos de seus rivais é a forma que Swift encontrou de desacreditar os relatos autobiográficos pseudoverazes e ao mesmo tempo “dizer a verdade na narrativa”. Qual é então essa verdade, que terá de ser transmitida pela sátira e que por implicação deve ser diversa da dos heróis progressistas? Já ficou evidente que o que estava em jogo não era uma mera opção epistemológica, mas um conflito entre duas visões de mundo antagônicas. Swift procurou atacar a ideologia progressista e contrapor-lhe uma alternativa conservadora, mas enfrentou o dilema comum dos satiristas — o de saber demolir mais do que construir ${ }^{164}$. Os veredictos negativos da sátira são muito claros; mais difícil é extrair dela uma mensagem construtiva.

Desde muito cedo apontou-se o parentesco de As Viagens de Gulliver com o gênero utópico. Muitas das propostas dispersas pelo livro - como a eugenia, a igualdade de instrução entre os sexos e a educação com exercícios físicos - encontram paralelos na República ou na Cidade do Sol. Thomas Sheridan, pai do dramaturgo e biógrafo de Swift, escreveu em 1784 que a quarta viagem “destina-se evidentemente a mostrar em que consiste a real dignidade e perfeição da natureza do homem, e a apontar os meios pelos quais ela pode ser atingida” ${ }^{65}$. Essa, todavia, era uma convicção de que nem todos partilhavam. O biógrafo inaugural de Swift, o conde de Orrery, foi talvez o primeiro a duvidar da exemplaridade dos

\footnotetext{
${ }^{164}$ São os termos com que Macaulay se refere a Voltaire em sua biografia de Frederico II. Cf. Ensaístas Ingleses. São Paulo: Clássicos Jackson, 1970, p. 232.

165 "is evidently designed to show in what the true dignity and perfection of man's nature consists, and to point out the way by which it may be attained." The Life of the Reverend Jonathan Swift. Em TCH, p. 234.
} 
Houyhnhnms, cujas virtudes consistiriam na mera incapacidade de praticar o mal ${ }^{166}$. A seriedade dos modelos sugeridos no livro se mostraria muito mais duvidosa que a dos descritos por Hitlodeu na Utopia. Até que ponto Swift desejava que o rei de Brobdingnag ou os cavalos inteligentes da quarta viagem fossem vistos pelos leitores como padrões louváveis de conduta? No que toca aos Houyhnhnms, a questão permanece até hoje em aberto. Mas uma coisa é certa: qualquer que tenha sido a opinião de Swift sobre os modelos e preceitos apresentados por Gulliver, eles nunca causaram grande impressão. Nem poderiam, imersos como estão sob uma massa de impropérios. Leitores escandalizados como Thackeray ${ }^{167}$ ilustram o fato de que os Yahoos sempre se impuseram com maior força à imaginação pública do que os Houyhnhnms. Se é verdade que a grande sátira, mais que denegrir, deve propor soluções, também é verdade que as conjecturais soluções propostas em Gulliver não têm o mesmo peso que os retratos da vileza humana que amargam suas páginas. A impressão comum do leitor que acaba de fechar o livro não é a de quão virtuoso o homem pode ser, mas a de quão vicioso ele é. Como diria Swift, seu principal propósito era "vexar o mundo, e não diverti-lo”168. Essa é uma diferença essencial entre As Viagens de Gulliver e obras mais claramente utópicas, como A República ou as Novas de Nenhures, de William Morris: na comparação entre o mundo real e o ideal, a ênfase de Swift recai sobre o primeiro. O lado utópico do livro serve como elemento de contraste que realça os contornos de seu lado antiutópico. Gulliver é, como resultado, um livro intrinsecamente pessimista.

As razões para isso eram muitas. Em 1721, quando Swift pôs mãos à redação, os tories praticamente inexistiam como partido parlamentar, e sua influência no campo padecia com a compra generalizada de votos, facilitada pelo alargamento do prazo entre as eleições (1716) e pela ação de grandes magnatas como o duque de Newcastle. O sistema de Dívida Nacional que ligava o Estado ao Banco da Inglaterra foi preservado, e com a influência do capital urbano as leis de repressão à dissidência religiosa começaram a cair — o que serviu para fortalecer os dissidentes e debilitar ainda mais os tories. Acrescente-se ainda a concessão

\footnotetext{
166 Remarks on the Life and Writing of Dr. Jonathan Swift, Dean of St. Patrick's, Dublin (1752). Em TCH, p. 127.

167 Para a visão de Thackeray sobre Swift, ver The English Humorists of the Eighteenth Century e os capítulos XI (livro I) e II (livro III) de Henry Esmond.

168 "to vex the world rather than divert it". Carta a Pope, em 29 de setembro de 1725. In GT, p. 261.
} 
calculada de sinecuras e a prática do apadrinhamento para garantir uma maioria whig nos Comuns. Ao contrário do que então se sugeria ${ }^{169}$, as instâncias executiva e legislativa na Inglaterra estavam longe de separadas, já que os membros do gabinete - como os secretários de Estado, o lorde chanceler e o primeiro-ministro - eram igualmente parlamentares, o que comprometia a função das câmaras de restringir o poder executivo. Seguros do apoio dos financistas, do parlamento e do eleitorado, os whigs se perpetuavam viciosamente no poder, dando continuidade, na visão de Swift, ao sistema perverso que interrompera em 1714 um projeto tory para salvaguardar a hierarquia social e a cultura. As Viagens de Gulliver são a retomada desse projeto numa fase de desencanto.

Verifiquemos agora como esses problemas ganham expressão no livro. Já vimos que Gulliver, embora seja a princípio uma imitação do herói progressista, não possui um caráter definido. Sujeito como está às exigências da sátira, ele oscila entre dois extremos, em um dos quais é objeto da sátira, sendo no outro o observador do ridículo alheio. Allan Bloom (para quem o livro é uma “descrição da natureza humana, e particularmente do homem político, à luz da grande cisão”), resumiu o esquema da seguinte maneira:

A fórmula é simplesmente esta: quando [Gulliver] é bom, os outros são maus; quando ele é mau, eles são bons. Os outros maus se encontram nos livros I e III, que tratam do reconhecidamente moderno. Os outros bons figuram nos livros II e IV, que estão, no mínimo, distantes da modernidade. ${ }^{170}$

A divisão é um pouco simplista, pois o enfoque satírico muda até mesmo dentro de cada viagem. A primeira metade do capítulo VI (parte I), por exemplo, interrompe a sátira com uma passagem utópica. No terceiro livro, vemos Gulliver ora como crédulo (ao louvar os Struldbruggs), ora como sensato (ao ver com admiração os primorosos domínios de Lorde

\footnotetext{
${ }^{169}$ V. Montesquieu, O Espírito das Leis, II, VI.

170 “Gulliver's Travels is a discussion of human nature, particularly of political man, in the light of the great split." "The formula is simply this: when he is good, the others are bad; when he is bad, they are good. The bad others are found in books I and III, which treat of the recognizably modern. The good others are in books II and IV, which are, at the least, removed from modernity.” Alan Bloom, “An Outline of Gulliver’s Travels”. In WJS, p. 649.
} 
Munodi). Mas a fórmula de Bloom proporciona um bom ponto de partida, sobretudo por chamar a atenção para o contraste entre a boa antigüidade e a modernidade corrupta. Quando Gulliver é bom (como na maioria das passagens em Lilliput ou Laputa), o que vê são abusos de poder, corrupção, desvarios intelectuais e empreendimentos absurdos. Quando ele é mau, o que vê são arranjos sociais desejáveis nos quais não encontra espaço, sendo como é um representante da Inglaterra e mais particularmente de sua camada progressista. Em um e outro caso, a ênfase recai sobre o lado negativo - que, escusa-se dizer, tem muito de whig. Nos trechos utópicos quem está em destaque é o observador, manifestação literária da mentalidade de classe média; nos trechos antiutópicos, é o observado, reprodução da sociedade inglesa em cores exóticas mas reconhecíveis.

As passagens que criticam o novo princípio de poder na Inglaterra são muitas; recordese, por exemplo, a afluência do partido Slamecksan (os whigs) em Lilliput, embora o Tramecksan seja reconhecidamente mais conforme à antiga constituição (I, iv); a ingratidão da rainha pelos esforços de Gulliver, no que é geralmente visto como uma alegoria das ações de Bolingbroke (I, v) ${ }^{171}$; o descaso pela agricultura tradicional em Balnibarbi (III, iv); o vil apreço dos Yahoos por pedregulhos coloridos (IV, vii); e as conversas de Gulliver com o rei de Brobdingnag. Este último caso traz um exemplo que merece citação extensa. Durante cinco audiências Gulliver retratou de modo idealista sua terra natal, após o que o rei, que se ocupara em tomar notas, passa a apresentar suas dúvidas.

Ele passou em seguida à administração de nosso tesouro, dizendo julgar que minha memória me falhara, porquanto eu computara nossos impostos em cerca de cinco ou seis milhões ao ano, mas à minha menção dos gastos ele notara que estes perfaziam amiúde mais que o dobro; e as notas que havia tomado eram muito precisas nesse sentido, já que ele esperava, segundo me disse, que o conhecimento de nossa conduta lhe pudesse ser útil, cumprindo-lhe assim não se enganar nos cálculos. Mas se o que eu lhe havia dito era verdade, ele não concebia como um reino podia dissipar seu patrimônio qual fora um particular. Perguntou-me quem eram nossos credores, e onde encontrávamos dinheiro para pagá-los. Admirou-se de me ouvir falar em guerras caras e

\footnotetext{
${ }^{171}$ A esse respeito, ver J. A. Downie, “The Political Significance of Gulliver’s Travels; Quintana, op. cit., p. 150; e Ehrenpreis, op. cit., p. 84.
} 
onerosas - certamente que éramos um povo belicoso, ou vivíamos entre péssimos vizinhos, e nossos generais seriam por necessidade mais ricos que nossos reis. Perguntou-me que negócios tínhamos fora de nossas ilhas, salvo nos misteres do comércio, de tratados ou da defesa costeira por nossas frotas. Acima de tudo, assombrou-se de me ouvir falar de um exército mercenário permanente em tempos de paz, no seio de um povo livre. ${ }^{172}$

Neste parágrafo concentram-se críticas ao sistema da Dívida Nacional, à Guerra da Sucessão Espanhola, ao suposto projeto de enriquecimento pessoal do duque de Marlborough (comandante das forças aliadas durante a guerra) e à manutenção do exército após a cessação de conflitos. Gulliver, que neste trecho é inconsciente dos defeitos de seu povo, só consegue manifestar pasmo quando o rei expressa dúvidas como a de "se um estranho de bolsa opulenta não poderia levar os eleitores comuns a escolhê-lo em vez do próprio senhor, ou do mais considerável gentil-homem das redondezas ${ }^{\text {173 }}$. O retrato ideal pintado pelo protagonista padece sob a crueza do bom senso do rei, para o prejuízo dos ingleses.

Passagens como esta se repetem e acumulam, maculando a dignidade de ministros, juristas, nobres, mercadores, médicos e até mestres de dança. O efeito geral é muito pouco lisonjeiro para a Inglaterra progressista. O rigor da sátira deve então ser compensado por um modelo corretivo, proporcionado neste caso pelos “outros bons” — os habitantes de Brobdingnag e os cavalos falantes. Que tal modelo não recebe grande destaque é algo que já observei. Mas de que natureza é esse contraponto positivo na sátira? Mesmo uma rápida leitura revela que Swift não contrasta os males da civilização com as virtudes do bon sauvage. Em Brobdingnag e no país dos Houyhnhnms o que vemos não são arranjos “naturais”, mas

\footnotetext{
${ }^{172}$ He fell next upon the Management of our Treasury; and said, "he thought my Memory had failed me, because I computed our Taxes at about five or six Millions a-year, and when I came to mention the Issues, he found they sometimes amounted to more than double; for the Notes he had taken were very particular in this Point, because he hoped, as he told me, that the Knowledge of our Conduct might be useful to him, and he could not be deceived in his Calculations. But, if what I told him were true, he was still at a loss how a Kingdom could run out of its Estate, like a private Person." He asked me, "who were our Creditors; and where we found money to pay them?" He wondered to hear me talk of such chargeable and expensive Wars; "that certainly we must be a quarrelsome People, or live among very bad Neighbours, and that our Generals must needs be richer than our Kings.” He asked, what Business we had out of our own Islands, unless upon the Score of Trade, or Treaty, or to defend the Coasts with our Fleet?” Above all, he was amazed to hear me talk of a mercenary standing Army, in the midst of Peace, and among a free People.” GT, II, vi, p. 109.

173 "whether a Stranger, with a strong Purse, might not influence the vulgar Voters to choose him before their own Landlord, or the most considerable Gentleman in the Neighbourhood?” Idem, p. 108.
} 
sociedades sofisticadas purgadas de excessos — em outras palavras, modelos de civilização não corrompida. Se na obra de Defoe encontramos pouca simpatia pela natureza intocada e grande admiração pelo engenho interventor do homem ${ }^{174}$, na de Swift encontramos não o retorno à natureza, mas o receio quanto aos abusos desse engenho.

Se ao fim [Gulliver] desenvolve uma aversão avassaladora por tudo o que há em sua terra, isso não ocorre porque a Europa sofra os males da civilização, mas por estar perdendo sua civilização e tombando num estado de corrupção degenerada. Não há talvez nenhuma outra viagem imaginária tão livre quanto As Viagens de Gulliver de quaisquer laivos de antitradicionalismo e com tão poucos ou tão mínimos detalhes de primitivismo cultural. ${ }^{175}$

O que há de utopia em Gulliver é assim estritamente tradicional: os traços dos “outros bons” são traços de uma aristocracia ideal que, no entender de Swift, constituía o melhor dos governos. Nobres cujo poder fosse fundado na posse de terras, e cuja educação esmerada os

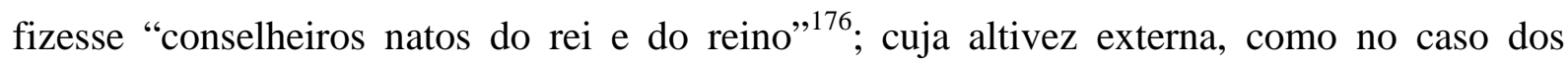
Houyhnhnms, fosse um indício de virtude interna ${ }^{177}$; que fizessem do governo uma arte límpida e sem mistérios escusos, assistidos nisso por uma fidalguia rural especialmente preparada ${ }^{178}$. A “política da nostalgia” - a crença numa idade de ouro em que a Inglaterra fora regida por uma aristocracia rural assaz habilitada — era invocada costumeiramente pelos tories para criticar o governo de Walpole ${ }^{179}$. Tratava-se de um modelo com o qual nenhum governo real poderia concorrer, e cujos proponentes ignoravam por conveniência os entraves práticos de sua aplicação. O que lhes interessava era o contraste entre real e ideal, e o

\footnotetext{
${ }^{174}$ Isso se observa idealmente em A Tour Through the Whole Island of Great Britain.

175 "If in the end [Gulliver] develops an overwhelming aversion to everything at home, it is not because Europe suffers the evil of civilization, but because it is losing its civilization and falling into a state of degenerate corruption. There is perhaps no other imaginary voyage as free as Gulliver's Travels of anything resembling anti-traditionalism, and very little or even the minor details of cultural primitivism.” Quintana, op. cit., p. 157.

${ }^{176}$ GT, II, vi, p. 106. Para a idéia de que Swift via como subversiva a separação entre a posse de terras e a posse de poder político, cf. Myrdin Jones, "Swift, Harrington and Corruption in England”.

${ }^{177}$ Cf. McKeon, The Origins of the Enblish Novel, p. 346.

${ }^{178}$ Cf. Samuel Holt Monk, “The Pride of Lemuel Gulliver”, em WJS, p. 639, e GT, II, vi, p. 107.

${ }^{179}$ W. A. Speck, “Politics”, em Pat Rogers (ed.), The Eighteenth Century, p. 100-101.
} 
conseqüente agigantamento das falhas dos whigs.

Esta vaga insinuação de crença na justiça de uma estratificação tradicional e aristocrática é inteiramente consistente, como argumentei, com a ideologia conservadora. É uma ficção socialmente útil, uma fé prudentemente instrumental que germina no solo deixado pelas flores da crença progressista depois que a crítica conservadora, para a sua própria satisfação, as desenraizou. ${ }^{180}$

A sociedade dos cavalos falantes, principal elemento utópico do livro, não é necessariamente um modelo a ser seguido. Sua função na narrativa constitui o principal motivo da polarização ocorrida durante o século XX entre as assim chamadas escolas de interpretação branda e rígida $^{181}$. Os adeptos da escola rígida declaram que os Houyhnhnms são de fato um padrão de virtude, ao passo que os da escola branda os vêem como outros tantos objetos da sátira. A despeito de quem tenha razão, o fato é que ainda que a sociedade dos cavalos seja apresentada como exemplar, seu ideal de razão absoluta e supressão das emoções é humanamente inimitável. Eles são no máximo um modelo para fins de comparação. “Os Houyhnhnms são menos uma afirmação do que o homem devia ser que uma afirmação do que ele não é."182 $\mathrm{E}$ essa impraticabilidade dos modelos caracteriza de modo geral o contraponto positivo na sátira de Gulliver.

O fato é que Swift, embora invocasse as virtudes da aristocracia ideal, já não tinha ilusões quanto à aristocracia real de seu tempo. Em seu Essay on Modern Education (1728) ele ataca a má formação dos nobres, que a seu ver fora corrompida em meados do século XVII pela morte de muitos luminares da nobreza na revolução e pelo novo status do homem de armas devido às guerras anglo-holandesas. Confiantes em sua excelência por nascimento,

\footnotetext{
180 “This ghostly insinuation of belief in the justice of a traditional, aristocratic stratification is entirely consistent, I have argued, with conservative ideology. It is a socially useful fiction, a cautiously instrumental faith that germinates in the soil left by the flowers of progressive belief once the conservative critique has, to its own satisfaction, quite deracinated them.” McKeon, op. cit., p. 344.

${ }^{181}$ O conceito dessa divisão foi proposto em 1974 por James L. Clifford, no ensaio “Gulliver’s Fourth Voyage: 'Hard and Soft Schools of Interpretation'”.

182 "[T] He Houyhnhnms are not a statement of what man ought to be so much as a statement of what he is not." Claude Rawson, “Gulliver and the Gentle Reader”, em WJS, p. 693.
} 
os nobres descuravam de educar-se devidamente, abrindo espaço aos "novos homens” de origem plebéia. Nas quarta viagem há um trecho em que se contrasta a nobreza ideal dos Houyhnhnms com a nobreza real da Inglaterra. Quando Gulliver menciona os nobres ingleses a seu mestre, este inicialmente se deixa iludir pelos conceitos vigentes entre os cavalos, mas Gulliver logo emenda

que a nobreza, entre nós, era algo totalmente diverso da idéia que ele dela fazia; que nossos jovens nobres eram instruídos desde a infância no ócio e na luxúria; que, tão logo lhes permitissem os anos, consumiam seu vigor e contraíam doenças odiosas entre fêmeas lascivas; e que, quando suas fortunas estavam à beira da ruína, esposavam (meramente pelo dinheiro) alguma mulher de nascimento espúrio e constituição enferma, que detestavam. ${ }^{183}$

A degeneração abria caminho para homens da pior espécie (e Swift tinha em mente Walpole):

O palácio de um primeiro-ministro é um seminário para formar outros em seu próprio ofício: os pajens, lacaios e porteiros, ao imitarem seu mestre, tornam-se ministros de Estado em seus vários distritos, e aprendem a excelir nos três ingredientes principais da insolência, da mentira e do suborno. Por conseguinte, têm uma corte subalterna que lhes é feita por pessoas da melhor posição; e às vezes, por força de destreza e impudência, chegam gradualmente a sucessores de seu senhor. ${ }^{184}$

Esta virulência não carece de certo ressentimento pessoal:

\footnotetext{
183 "that Nobility, among us, was altogether a different Thing from the Idea he had of it; that our young Noblemen are bred from their Childhood in Idleness and Luxury; that, as soon as Years will permit, they consume their Vigour, and contract odious Diseases among lewd Females; and when their Fortunes are almost ruined, they marry some Woman of mean Birth, disagreeable Person, and unsound Constitution (merely for the Sake of Money), whom they hate and despise.” GT, IV, vi, p. 217.

184 “The palace of a chief Minister is a Seminary to breed up others in his own Trade: the Pages, Lackeys, and Porters, by imitating their Master, become Ministers of State in their several Districts, and learn to excel in the three principal Ingredients, of Insolence, Lying, and Bribery. Accordingly, they have a subaltern Court paid to them by Persons of the best Rank; and sometimes by the Force of Dexterity and Impudence, arrive, through several Gradations, to be Successors to their Lord.” Idem, p. 216.
} 
A pior marca que se pode receber [de um ministro de Estado] é uma promessa, especialmente se confirmada por uma jura - após o que o homem sábio se retira, renunciando a toda e qualquer esperança. ${ }^{185}$

Num ensaio que se tornou famoso, George Orwell exaltou (em termos por vezes contestáveis) o perfil reacionário de Swift. Eis uma passagem de especial interesse:

Ele é um anarquista tory que despreza a autoridade enquanto descrê da liberdade, e preserva a visão aristocrática embora veja claramente que a aristocracia existente é degenerada e desprezível. Quando Swift profere uma de suas características diatribes contra os ricos e poderosos, provavelmente devemos, como sugeri mais acima, dar um desconto pelo fato de que ele próprio pertencia ao partido menos bem-sucedido e estava pessoalmente desapontado. ${ }^{186}$

Não me parece que Swift, admirador da república romana, possa ser designado como anarquista, nem que fosse descrente da liberdade. Mas o excerto é ainda assim penetrante. A filiação de Swift à “política da nostalgia” resulta tanto de sua natural inclinação conservadora como dos dissabores que ele sofreu após a queda do ministério. O azedume particular de seus escritos deve muito a essa identificação pessoal com o destino de uma classe e seus princípios. Que a fidalguia rural permanecesse a principal força econômica durante o século XVIII é um fato que não teve lugar na crítica de Swift, cujos olhos se voltavam em outra direção, oscilando entre um presente corrupto e um passado irrestaurável.

A superação dos tories pelos whigs em 1714 constituíra um duro golpe para os

\footnotetext{
185 "The worst Mark you can receive is a Promise, especially when it is confirmed with an Oath; after which, every wise Man retires, and gives over all Hopes.” Ibidem, p. 215.

186 "He is a Tory anarchist, despising authority while disbelieving in liberty, and preserving the aristocratic outlook while seeing clearly that the existing aristocracy is degenerate and contemptible. When Swift utters one of his characteristic diatribes against the rich and powerful, one must probably, as I said earlier, write off something for the fact that he himself belonged to the less successful party, and was personally disappointed." Orwell, "Politics vs. Literature: An Examination of Gulliver's Travels", em The Collected Essays, Journalism and Letters of George Orwell. Vol. IV., p. 216.
} 
princípios ideológicos e as ambições pessoais de Swift. Em sua condição de excluído ele interpretou a história segundo uma ótica conservadora cujo vínculo com a tradição se desfizera, mas cujo apego a um modelo ideal de virtude preservara-se como trampolim para a crítica aos valores progressistas. A robinocracia da década de 1720 só veio confirmar seus receios da preponderância do partido whig, e após seus primeiros sucessos nas polêmicas impressas da Irlanda ele retomou a discussão que abandonara com a queda do ministério. A oposição aos valores progressistas condicionou tanto o conteúdo como a forma das Viagens de Gulliver, retomando em partes um antigo debate político e literário, e retomando-o com um teor negativista - o teor de quem vê o mundo antigo dando lugar a um outro mundo, corrupto e decadente. 
PARTE 3

Conclusão 


\subsection{Conclusão}

Não seja o primeiro por quem o novo é tentado, E tampouco o último a pôr o velho de lado. ${ }^{187}$ Pope, “An Essay on Criticism”, 335-6.

A época de Swift é uma época de transformações, em que os modelos antigos estão perdendo a validade e abrindo espaço a modelos novos nem sempre atraentes. Esse dilema está no cerne de As Viagens de Gulliver. Swift representa um dos lados do debate então fremente, e, se fiz freqüentes alusões a Defoe, não o fiz porque ele seja o alvo específico da sátira de Gulliver, mas porque representa idealmente o outro lado. Como observou Nigel Dennis:

Swift é o autor gentil-homem cujo lar de escolha é a sociedade e a esfera dignificada dos bem educados e bem nascidos; Defoe é o nativo de Grub Street, pai de tudo o que é mais ruidoso e livre no jornalismo moderno (...), e investe em direção aos tempos modernos na mesma proporção em que Swift recua para a época anterior. Quando temos em mãos a obra-prima de cada um, seguramos as metades de um pomo — o pomo da discórdia que, em sua inteireza, representa a Inglaterra do século XVIII. ${ }^{188}$

Robinson Crusoé e As Viagens de Gulliver, obras à primeira vista tão similares — ambas são relatos de náufragos escritos tardiamente por polemistas à beira dos 60 anos, e partilharam o

\footnotetext{
187 "Be not the first by whom the new are tried, / Nor yet the last to lay the old aside."

188 "Swift is the gentleman-author whose chosen home is society and the dignified sphere of the well-educated and well-born; Defoe is the born gander of Grub Street, the father of all that is noisiest and freest in modern journalism. (...), and he presses forward into modern times proportionately as Swift fights backwards into the time behind him. When we hold each man's masterpiece in our hands we hold the halves of one apple - the apple of discord that in its wholeness, represents the England of the eighteenth century." "Defoe and Swift", in WJS, p. 662.
} 
fado comum de se tornarem clássicos juvenis — , registram e ilustram num microcosmo a grande crise de seu tempo. Elas funcionam qual fossem proposição e réplica. As implicações de Robinson Crusoé para a esfera conservadora eram nítidas. Ao tratar do trajeto de Defoe da panfletagem aos romances, Paula Backscheider observou:

\begin{abstract}
Nas histórias secretas ele passava amiúde de acontecimentos reais para acontecimentos que podiam ser reais e para incidentes que ele desejava fossem reais; todos tinham os mesmos propósitos políticos e morais. Ele ficou mais e mais disposto a usar eventos para ilustrar idéias específicas. Suas obras de propaganda se tornaram mais e mais longas. (...) Certo de um mercado para o que quer que escrevesse, Defoe começou a se comprazer e, sem mais desculpas, a subordinar a verdade histórica a considerações ideológicas e pessoais. ${ }^{189}$
\end{abstract}

A pretensão de veracidade - de que o que se escreve "não é uma estória, mas uma História”190 — tinha amiúde fins casuísticos. No caso de Defoe isso fica especialmente claro, já que sua prosa de ficção brotou pouco a pouco de sua atividade como polemista, preservando o enviesamento original. Seus heróis, com suas aventuras "reais”, pareciam provas genuínas do valor do empreendedorismo. Por essa altura a busca de um meio comum para o tratamento simultâneo de problemas epistemológicos e sociais estava adiantada, e o falso historicismo se associava mais e mais aos valores progressistas. As convenções narrativas de Robinson Crusoé eram vistas como daninhas pela elite intelectual porque constituíam a expressão literária da mentalidade de classe média. Na réplica que Swift ofereceria, a crítica ao etos burguês se associaria a uma atitude epistemológica específica. Essa réplica, no entanto, está marcada pelo fato gerador da crise: a caducidade dos valores tradicionais.

A virtude da aristocracia vinha cedendo lugar à dos empreendedores, e isso se refletia

\footnotetext{
189 "In secret histories he often moved from real events to events that might be real to incidents that he wished real; all had the same political and moral purposes. He became more and more willing to use events to make particular points. His propaganda works become longer and longer. (...) Sure of a market for whatever he wrote, Defoe began to indulge himself and to subordinate historical truth unapologetically to ideological and personal considerations.” Backscheider, Daniel Defoe: His Life, pp. 410-411.

190 “is not a Story, but a History”. Defoe, Roxana, p. 35.
} 
necessariamente na literatura. A estória romanesca, ficção da honra aristocrática, era uma relíquia da Restauração (capítulo 1.2). O apego a esse gênero em pleno século XVIII seria um saudosismo caduco como o de Dom Quixote. Não por acaso, o Female Quixote (1752) de Charlotte Lennox ridicularizaria o gosto anacrônico pelos heróis do filão seiscentista. Não só o romanesco perdera seu espaço, como a literatura palaciana e o credo neoclássico estavam se esgotando, em razão da brecha crescente entre escritores e nobres e da incerteza com que o neoclassicismo se assentara na Inglaterra desde o início (capítulo 1.1). Sem um piso firme na tradição — fosse o vínculo entre posse de terras e posse de poder, fosse a literatura romanesca ou palaciana — os tories e os augustanos precisaram ajustar-se aos novos tempos e participar também eles do movimento de renovação, submetendo-o porém a sua própria crítica. Eles empreenderam uma renovação moderada que preservava o que parecia válido na tradição, como meio de refrear os excessos progressistas. E fizeram-no sobretudo quando seu objetivo era contrastar os bons modelos do passado com a degeneração presente. O que se resgatava de outros tempos não precisava se refletir na realidade, desde que servisse de munição. Assim como os tories atacavam os whigs com base num ideal de nobreza que se perdera num passado utópico (capítulo 2.4), os autores augustanos, ao julgarem a literatura popularesca, invocavam normas neoclássicas que eles próprios não aceitavam de todo (capítulo 1.2). Como resultado, em muitos momentos a resposta desses conservadores foi mais eficiente em denunciar os problemas do progresso do que em propor modelos alternativos.

Muito eficientes como crítica da modernidade, As Viagens de Gulliver são todavia ambíguas quando se trata de oferecer soluções válidas. Já o vimos no plano político, mas o mesmo vale no literário. As Viagens de Gulliver não fundam um gênero novo, nem filiam-se a alguma corrente alternativa com uma proposta estética autônoma. O livro, afinal, é famosamente uma sátira. Esse termo, que na Antigüidade havia nomeado um gênero, passara com o tempo a designar meramente uma atitude retórica ${ }^{191}$, a atitude de expor um réu ao julgamento do leitor, induzindo-o a absolver ou condenar — e, no caso de Gulliver, a condenar. O que Swift fez foi transplantar essa intenção retórica do tradicional poema augustano - como MacFlecknoe ou An Epistle to Dr. Arbuthnot - para a mesma prosa de ficção que ele punha no banco dos réus. No esforço por se apropriar das convenções das

\footnotetext{
${ }^{191}$ Cf. James Sutherland, English Satire, p. 5, e Ian Jack, Augustan Satire, 97-99.
} 
formas modernas, o livro se afastou drasticamente dos padrões augustanos. Enumeremos algumas regras neoclássicas: unidade de concepção, linguagem decorosa, expurgo dos detalhes secundários, consistência na caracterização dos personagens... onde fica Gulliver em meio a tudo isso? Podemos responder que está em viagem a novos territórios, que deixou o reduto estrito do augustanismo e invadiu a província de seus inimigos. "Taticamente, Swift como satirista é um quinta-coluna que adota o uniforme do oponente para sabotar por dentro a fortaleza." ${ }^{192}$ Ao afastar-se da base da tradição e engalfinhar-se com as novas formas em seu próprio território, Swift fez de seu livro um ato de destruição que, após a remoção dos destroços, não se ocupou necessariamente de reconstruir. Ele recorreu, é certo, a muitas convenções preexistentes — o ridículo rabelaisiano, o relato utópico, a viagem imaginária —, mas o que criou foi um espécime exótico, e não um ramo frutífero. Daí as dificuldades da crítica de classificar As Viagens de Gulliver de forma definitiva. Trata-se afinal de uma obra que subsiste não tanto pelo que propõe, como pelo que rejeita. É um livro combativo desde suas raízes — as desiludidas raízes do reinado de Ana — , que manteve em tempos posteriores o projeto scribleriano de responder às novas vozes da literatura. É, enfim, um livro que não procura tanto ser uma certa coisa, como não ser uma outra.

Que outra coisa era essa? As convenções que As Viagens de Gulliver combatem não caracterizavam apenas Robinson Crusoé ou os relatos de viagens em geral, aos quais principalmente me ative. Basta repassá-las e seu verdadeiro alcance fica evidente: o que Swift está renegando são narrativas pseudoverazes em primeira pessoa cujo conteúdo fica submetido ao crivo de uma consciência individual e cujos traços comuns são o interesse num destino pessoal, a associação com o mundo real, a ênfase em detalhes da vida quotidiana, a precisão temporal e geográfica, e a linguagem referencial. São, enfim, as características de uma prosa de ficção em desenvolvimento que, num estágio posterior de maturação, constituiria o que conhecemos inequivocamente como o romance (capítulo 1.3).

J. Paul Hunter observa que “certos críticos de Swift têm assomos de apoplexia quando a

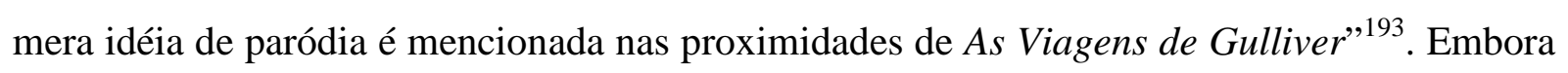

\footnotetext{
192 “Tactically, Swift as a satirist is a fifth-columnist, adopting his opponent's uniform in order to sabotage from within the fortress.” Probyn, Jonathan Swift: The Contemporary Background, p. 4.

193 “some Swift critics lurch toward apoplexy when the very idea of parody is broached within reaching distance of Gulliver's Travels”. Hunter, “Gulliver's Travels and the Novel”, in GGT, pp. 65-6.
} 
eu não tenha usado a palavra até aqui, ela deve ter ocorrido mais de uma vez ao leitor: a Parte 2, para darmos às coisas seus devidos nomes, foi em grande medida um estudo dos métodos paródicos em Gulliver. A paródia - “a adoção e o exagero conscientes das convenções e excessos estilísticos de obras ou gêneros literários identificáveis”194 — foi um recurso a que Swift recorreu repetidamente ao longo de sua carreira. O Conto do Tonel parodia as excentricidades de autores do século XVII ${ }^{195}$; o Argument against abolishing Christianity parodia em variados níveis o estilo dos polemistas cristãos; os Bickerstaff Papers parodiam os almanaques populares e sua dose de astrologia. Outros exemplos são A Meditation upon a Broomstick, Mr. Collins’ Discourse on Free-Thinking e a Modesta Proposta. A paródia era uma arma que se ajustava muito bem aos propósitos de Swift, autor que raramente recorria à invectiva direta ${ }^{196}$ e que preferia arremedar pejorativamente seus adversários. Essa, como espero ter demonstrado, é uma das estratégias principais de As Viagens de Gulliver. Se existe certa relutância crítica em reconhecer o elemento paródico no livro, ela se deve a dois equívocos possíveis que devemos evitar: o primeiro é considerá-lo unicamente como paródia - como uma paródia persistente e prolongada; o segundo, apontado entre outros por Hunter, é julgar que seus trechos paródicos aludem sempre a uma mesma obra. Em Gulliver a paródia, como de resto a alegoria e o enfoque satírico, é inconsistente. O segundo capítulo da viagem a Lilliput, por exemplo, encerra-se com um inventário do que Gulliver levava nos bolsos ao naufragar, e que Hunter considera uma alusão paródica aos atulhados bolsos de Robinson Crusoé; no terceiro capítulo a chave é outra: passamos à corrupção da corte, e o tom, embora satírico, já não é paródico - já não envolve a imitação deliberada dos excessos de outras obras. Tais lapsos na paródia são freqüentes. Quanto ao segundo problema, As Viagens de Gulliver não parodiam especificamente Robinson Crusoé nem qualquer obra. Seu alcance é mais geral:

O exemplo dos bolsos alusivos sugere que As Viagens de Gulliver são, entre muitas outras

\footnotetext{
194 "the conscious adoption and exaggeration of the conventions and stylistic excesses of identifiable literary works or genres”. Roger D. Lund, "Parody in Gulliver's Travels”, in Approachings to Teaching Swift's Gulliver's Travels, p. 81

195 Cf. Ronald Paulson, “The Parody of Excentricity”, in Bloom (ed.), Jonathan Swift: Modern Critical Views.

${ }^{196}$ Cf. Bullitt, Jonathan Swift and the Anatomy of Satire, p. 38.
} 
coisas impressionantes, uma paródia cumulativa genérica ou classista não somente das narrativas de viagens em si, mas também de uma classe maior e emergente de narrativas ficcionais em primeira pessoa que fazem asserções extraordinárias quanto à importância do contemporâneo, da cognoscibilidade de grandes padrões cósmicos mediante a experiência pessoal, da significância do indivíduo e das possibilidades imperialistas da mente humana uma paródia classista, em suma, do que hoje vemos como o romance e as premissas que o possibilitam. ${ }^{197}$

Tudo isso, para retomar os termos de McKeon, ocorre às vésperas da obtenção da identidade canônica por parte do romance. Nesse momento o vínculo entre questões de verdade e questões de virtude é muito forte: a antiga crítica de Swift à ideologia progressista encontra vazão numa forma que, em essência, parodia os desvarios do empirismo simplório - numa paródia não contínua, mas intermitente, e não de uma dada obra, mas das convenções soltas de um futuro gênero. O resultado é um consórcio simbiótico entre a ideologia conservadora e o ceticismo extremo, com a conseqüente retomada parcial dos valores da tradição (cf. p. 37). Se as características do romance em formação constituem a expressão literária de um novo modo de pensar, o que encontramos em Gulliver é a expressão reformulada de um pensamento mais tradicional. Em ambos os casos a escolha do modelo literário atrela-se inextricavelmente a um certo juízo social. No plano literário Gulliver é uma resposta sofisticada a um gênero em busca de sofisticação, a réplica paródica de um augustanismo que rui e cujas formas tradicionais, por si só, já não bastam para o embate crítico numa época de decadência palaciana e popularização das letras, e que por isso mesmo precisa aderir parcialmente às regras do novo jogo. O livro não é ainda uma proposta de renovação, um exemplo a ser imitado: é um palco em que as novas tendências e convenções tropeçam em suas próprias fragilidades. No plano social, Gulliver representa a atitude de toda uma classe que vinha então perdendo as rédeas do poder e que assistia com amargura à

\footnotetext{
197 “The example of the allusive pockets suggests that Gulliver's Travels is, among many other impressive things, an accreting generic or class parody not only of travel narratives per se but also of a larger developing class of first-person fictional narratives that make extraordinary claims for the importance of the contemporary, the knowableness through personal experience of large cosmic patterns, the significance of the individual, and the imperialistic possibilities of the human mind - a class parody, in short, of what we now see as the novel and the assumptions that enable it.” Hunter, op. cit., p. 69.
} 
ascensão de arrivistas que, sem título e sem sangue, alçavam-se à preeminência social e política. Esses novos homens e seu novo gênero servem de sujeito e objeto em As Viagens de Gulliver, e fazem-no para seu próprio deslustre. O que resta, depois desse exercício de desabono, são sérias dúvidas quanto à possibilidade de corrigir as estruturas sociais e reajustar os rumos da literatura.

Mas isso não é tudo. Não pretendo deixar a impressão de que Gulliver foi uma mera reação acerba ao romance, sem mais conseqüências. Basta pensar em Fielding, Sterne, Johnson e até mesmo Goldsmith para saber que a história do romance no século XVIII não se limitou às narrativas pseudoverazes nem às ficções de honra da classe mercante. A entrada em campo de escritores com históricos diferentes, mas com confiança no valor do novo gênero, submeteu-o a uma transformação duradoura. Se Swift não apresentou uma alternativa consistente ao romance progressista, ainda assim ele apontou caminhos para novos autores. Não o fez, porém, pelo caminho das paródias positivas que Bakhtin identificou na cultura popular medieval e que “corporificavam, materializavam e ao mesmo tempo aligeiravam tudo o que tocavam”198. O século XVIII, com seu “utopismo abstrato e racionalista”, já havia abandonado totalmente o espírito cômico e solidário do riso medieval, insistindo tão-somente no aviltamento do objeto parodiado. Em Swift a rejeição dos traços parodiados é incondicional; nele, como em Voltaire, “o positivo é exterior ao riso e confina-se no domínio da idéia abstrata”199. Se Gulliver teve também um lado construtivo, isso ocorreu não por alguma ambigüidade da paródia, mas sim por um paradoxo:

[O] paradoxo da paródia, pelo qual a paródia cria novas expressões a partir da expressão de que procura escarnecer, significa que ela preserva tanto quanto destrói, ou, antes, que preserva no momento mesmo em que destrói - e com isso o parasita tem ocasião de servir ele próprio

\footnotetext{
198 Bakhtin, A Cultura Popular na Idade Média e no Renascimento, p. 72.

${ }^{199}$ Idem, p. 100.
} 
como hospedeiro. ${ }^{200}$

A paródia, por definição, não é uma reprodução idêntica do objeto parodiado: a destruição que ela provoca depende de sua distinção em certos sentidos. E Gulliver deixou raízes na medida em que se distinguiu do romance em formação. Trata-se de uma obra que, embora caçoe das narrativas de seu tempo, é também uma narrativa com atrativos capazes de envolver os leitores - demonstra-o sua conversão em clássico da literatura juvenil —, salvo que com outra atitude epistemológica. Nesse sentido postura de Swift assemelha-se curiosamente à de Shaftesbury, autor com quem ele se parece bem pouco. Para criticar os modernos desvios de gosto, Shaftesbury escolhe como exemplo ilustrativo os livros de viagens. Esse gênero tergiversa com dados sobre “estalagens e ordinárias, barcos e balsas de passagem, tempo bom e ruim”, estendendo-se em descrições “da dieta, dos hábitos corporais, dos perigos pessoais e dos infortúnios do autor em terra e mar”, apenas para iludir o leitor e conduzi-lo a alguma grande cena de ação povoada de monstros. "De bestas monstruosas ele passa a homens ainda mais monstruosos. Pois nessa raça de autores o mais completo e de mais alto nível é o capaz de dizer as coisas mais desnaturadas e monstruosas”201. Os relatos de viagens, enfim, são um gênero escrito por autores sem gênio para leitores de mau gosto.

É o mesmo gosto que nos faz preferir uma história turca a uma grega ou romana, um Ariosto a um Virgílio, e um romance ou novela a uma Ilíada. Não fazemos o menor caso do caráter ou gênio de nosso autor, nem estamos curiosos por ver quão hábil ele é no julgamento dos fatos ou quão engenhoso na textura das mentiras. Pois fatos relatados ineptamente, embora com a maior sinceridade e boa fé, podem se mostrar a pior espécie de logro; e puras mentiras, judiciosamente

\footnotetext{
200 " [T] $]$ he parodic paradox, by which parody creates new utterances out of the utterances that it seeks to mock, means that it preserves as much as it destroys — or rather, it preserves in the moment that it destroys — and thus the parasite becomes the occasion for itself to act as a host.” Dentith, Parody, p. 189.

201 "inns and ordinaries, passage boats and ferries, foul and fair weather, with all the particulars of the author's diet, habit of body, his personal dangers and mischances on land and sea." "From monstrous brutes he proceeds to yet more monstrous men. For in this race of authors he is ever completest and of the first rank who is able to speak of things the most unnatural and monstrous." Shaftesbury, "Advice to an Author", in Characteristics of Men, Manners, Opinions, Times (1711). In ECCE, p. 208.
} 
compostas, podem nos ensinar a verdade das coisas, mais que qualquer outro método.”202

Esta última passagem sugere uma alternativa ao simulacro da verdade - alternativa a que McKeon chamou ceticismo extremo, e que consiste na refutação das pretensões historicistas em prol de uma narrativa que, embora assumidamente ficcional, aborde problemas do mundo real. Essa é a estratégia que os céticos encontram de “dizer a verdade na narrativa”. E é a estratégia que justifica a incursão de Swift pela prosa de ficção. Ele de modo algum negava o valor da fábula como transmissora de lições morais; em sua Letter to a Young Gentleman, ele observa: "Fui mais bem entretido e informado por um único capítulo do Progresso do Peregrino do que por algum longo discurso sobre a vontade e o intelecto ou sobre idéias simples ou complexas”203. A ficção, para Swift, é tolerável desde que não invada a província da história e desde que instrua o leitor, indo além do deleite. Em sua crítica ao falso historicismo dos escritores progressistas, Swift retorna portanto a uma atitude epistemológica mais antiga - que é a de Luciano e Rabelais, mas é também a das parábolas bíblicas, a de Esopo e, por incrível que pareça, a da própria estória romanesca em sua variedade histórica (cf. p. 24). A esse respeito McKeon comenta:

[A]o subverter a epistemologia empírica, Swift contribui, tão plenamente quanto Defoe o faz ao favorecê-la, para o crescimento das idéias modernas do realismo e da espiritualidade internalizada do estético. A pedagogia parabólica de Swift pode justificar tacitamente seu retorno a uma atitude anacrônica quanto ao modo de dizer a verdade na narrativa, em partes, porque conquistou o direito de fazê-lo mediante a evisceração autoconsciente da alternativa mais moderna. ${ }^{204}$

\footnotetext{
202 "It is the same taste which makes us prefer a Turkish history to a Grecian or a Roman, an Ariosto to a Virgil, and a romance or novel to an Iliad. We have no regard to the character or genius of our author, nor are so far curious as to observe how able he is in the judgment of facts, or how ingenious in the texture of his lies. For facts unably related, though with the greatest sincerity and good faith, may prove the worst sort of deceit; and mere lies, judiciously composed, can teach us the truth of things beyond any other manner.” Idem.

203 "I have been better entertained, and more informed, by a Chapter in the Pilgrim's Progress, than by a long Discourse upon the Will and the Intellect, and simple or complex ideas.” In Eddy (ed.), Swift's Satires and Personal Writings, p. 287.

204 “[B]y subverting empirical epistemology, Swift contributes, as fully as Defoe does by sponsoring it, to the growth of modern ideas of realism and the internalized spirituality of the aesthetic. Swift's parabolic pedagogy
} 
No decorrer do século a pretensão de veracidade acabará saindo de cena, e a capacidade do romance de refletir ficcionalmente sobre a “natureza humana” e o mundo real será reconhecida. Gulliver, se não chegou a constituir um espécime genuíno de romance conservador, foi não obstante um precedente conspícuo. Seu exemplo está presente em Fielding e em outros autores que praticaram o romance a sério mas renunciaram aos clamores de veracidade. Swift é um dos elos lógicos entre a obsolescente literatura neoclássica e o gênero em ascensão, e ocupa com relação a Fielding uma posição similar à de Defoe com relação a Richardson. A diferença essencial é que ele não apostou no futuro da forma, e como resultado Gulliver ficou perdido entre dois tempos - entre o tarde demais e o demasiado cedo.

O futuro lhe daria herdeiros mais diretos: obras como Erewhon, de Samuel Butler, 1984, de George Orwell, e Admirável Mundo Novo, de Huxley, serão tributárias evidentes de seu ilustre predecessor. As sementes deixadas por Swift também chegaram a terrenos menos evidentes, germinando na obra de escritores tão variados como Laurence Sterne e H. G. Wells. O que disse Claude Rawson do Conto do Tonel pode aplicar-se também a Gulliver: “[F]oi a extraordinária elaboração de um estilo paródico por Swift que criou paradoxalmente novas possibilidades de auto-expressão para o mesmo modernismo a que ele estava resistindo.”205 Observei em certo momento que a adesão de Swift à prosa de ficção era a adesão de um vírus. Mas a forma soube absorver o vírus e desenvolver anticorpos, fortalecendo-se em conseqüência. As Viagens de Gulliver parodiam e ilustram de um só fôlego a nova tendência, e, no ato mesmo de refutá-la, inadvertidamente a enriquecem. É esse o seu papel ambíguo na conturbada história do romance inglês.

É assim que fica Gulliver nessa história.

can tacitly justify its return to an anachronistic attitude toward how to tell the truth in narrative in part because it has, as it were, earned the right to do it through a self-conscious evisceration of the more modern alternative.” McKeon, The Origins of the English Novel, p. 351.

205 “[I]t was Swift's extraordinary elaboration of a parodic style that paradoxically created new possibilities of self-expression for the very modernism he was resisting." Rawson, “Introduction”, em Jonathan Swift: A Collection of Critical Essays, p. 7. 


\section{Bibliografia}

\section{Fontes Primárias}

ARBUTHNOT, John; SWIFT, Jonathan; POPE, Alexander; et alii. The Memoirs of the Extraordinary Life, Works, and Discoveries of Martinus Scriblerus. Charles Kerby-Miller, editor. Oxford, OUP, 1988.

SWIFT, Jonathan. The Journal to Stella. Together with Other Writings Relating to Stella and Vanessa. Introdução e notas de Sir Walter Scott. Londres: George Newnes, 1904.

. A Modest Proposal and Other Writings. Köln: Könemann, 1997.

. A Tale of a Tub and other works. Edição e introdução de Angus Ross e David Wooley.

Nova Iorque: Oxford University Press, 1990.

. Gulliver's Travels. Edição Crítica de Alberto J. Rivero. Londres: W. W. Norton \& Company, 2001.

. Gulliver's Travels. Edição e introdução de Paul Turner. Oxford: Oxford University Press, 1986.

- Selected Prose Works of Jonathan Swift. Edição de John Hayward. Londres: The Cresset Press, 1949.

. Swift's Satires and Personal Writings. Edição de William Alfred Eddy. Londres: Oxford University Press, 1951.

. The Basic Writings of Jonathan Swift. Edição de Claude Rawson. Nova Iorque: Modern Library, 2002.

. The Writings of Jonathan Swift. Edição crítica de Robert Greenberg e William Piper Londres: W. W. Norton \& Company, 1973. 


\section{Literatura Crítica}

AITKEN, George Atherton. “Swift”. In: The Cambridge History of English Literature, v. 9 From Steele and Addison to Pope and Swift. Cambridge: Cambridge University Press, 1934. P. 91-128.

ALLEN, Walter. (1954) The English Novel: A Short Critical Study. (Londres: Penguin Books, 1999)

BLOOM, Harold (ed.) Jonathan Swift: Modern Critical Views. Chelsea House, 1986.

BULLITT, John. Jonathan Swift and the Anatomy of Satire. Cambridge: Harvard University Press, 1966.

BUTT, John. The Augustan Age. Londres: Hutchinson’s University Library, 1950.

CRAIK, Henry. The Life of Jonathan Swift. Londres: Macmillan and Co., 1894.

DAVIS, Lennard J. Factual Fictions: The Origins of the English Novel. Filadélfia: University of Pennsylvania Press, 1997.

DAY, Geoffrey. From Fiction to the Novel. Londres: Routledge \& Kegan Paul, 1987.

DENTITH, Simon. Parody. The New Critical Idiom. Londres: Routledge, 2000.

DePORTE, Michael. “Avenging Naboth: Swift and Monarchy”. Philological Quarterly, Iowa: The University of Iowa, v. 69, n. 4, p. 419-433. Outono de 1990.

DUCKWORTH, Alistair M. “ 'Whig’ Landscapes in Defoe’s Tour”. Philological Quarterly, Iowa: The University of Iowa, v. 61, n. 4, p. 453-465. Outono de 1982.

EDDY, William A. Gulliver's Travels: A Critical Study. Gloucester, Peter Smith, 1963.

EHRENPREIS, Irvin. The Personality of Jonathan Swift. Londres: Methuen, 1958.

JEFFERSON, D. W. (1957) "Swift and the Tradition of Wit”. In: FORD, Boris (ed.). The New Pelican Guide to English Literature 4. From Dryden to Johnson. Londres: Penguin Books, 1997. p. 195-213.

FOX, Christopher (ed.) The Cambridge Companion to Jonathan Swift. Cambridge, CUP, 2003. 
GOVE, Philip Babcock. The Imaginary Voyage in Prose Fiction. Nova Iorque: Octagon Books, 1975.

GLENDINNING, Victoria. Jonathan Swift. A Portrait. Nova Iorque: Henry Holt and Company, 1998.

HUNTER, J. Paul. Before Novels. The Cultural Contexts of Eighteenth-Century English Fiction. Nova Iorque/Londres: W. W. Norton \& Company, 1990.

IRWIN, W. R. "Swift and the Novelists”. Philological Quarterly, Iowa: The University of Iowa, v. 45, n. 1, p. 102-113. Outono de 1966.

JONES, Myrddin. “Swift, Harrington and Corruption in England”. Philological Quarterly, Iowa: The University of Iowa, v. 53, n. 1, p. 59-70. Janeiro de 1974.

KETTLE, Arnold. An Introduction to the English Novel, V. I. Defoe to George Eliot. Nova Iorque: Harper Torchbooks, 1960.

KLIMA, S. “A Possible Source for Swift’s Struldbrugs?” Philological Quarterly, Iowa: The University of Iowa, v. 42, n. 4, p. 566-569. Outubro de 1963.

McKEON, Michael. The Origins of the English Novel. 1600-1740. Baltimore: Johns Hopkins University, 1988.

McMINN, Joseph. Jonathan Swift. A Literary Life. Londres: MacMillan, 1991.

NEILL, S. Diana. A Short History of the English Novel. Nova Iorque: Collier Books, 1964.

NOKES, David. Jonathan Swift. A Hypocrite Reversed. Oxford, OUP, 1985.

ORWELL, George. “Politics vs. Literature: An Examination of Gulliver's Travels. In: The Collected Essays, Journalism and Letters of George Orwell. Vol. IV. Londres: Secker \& Warburg. 19xx.

PAULSON, Ronald. Satire and the Novel in Eighteenth-Century England. New Haven, Yale University Press, 1967.

PROBYN, Clive T. English Fiction of the Eighteenth Century. 1700-1789. Nova Iorque: Longman, 1987. 
. Jonathan Swift: The Contemporary Background. Nova Iorque: Barnes \& Noble, 1979.

. The Art of Jonathan Swift. Nova Iorque: Barnes \& Noble, 1978.

QUINTANA, Ricardo. Swift: An Introduction. Londres: Oxford University Press, 1962.

RAWSON, Claude (ed.) Jonathan Swift: A Collection of Critical Essays. Upper Saddle River, Prentice-Hall, 1995.

REICHERT, John F. "Plato, Swift and the Houyhnhnms”. Philological Quarterly, Iowa: The University of Iowa, v. 47, n. 2, p. 179-192. Abril de 1968.

RICHETTI, John (ed.). The Cambridge Companion $t$ the Eighteenth-Century Novel. Cambridge, CUP, 1996.

RIELLY, Edward. Approaches to Teaching Swift's Gulliver's Travels. Nova Iorque: The Modern Language Association of America, 1988.

ROSENHEIM, E. W., Jr. “Swift and the Martyred Monarch”. Philological Quarterly, Iowa: The University of Iowa, v. 54, n. 1, p. 178-194. Inverno de 1975.

SHIMADA, Takau. "Possible Sources for Gulliver's Travels.” Philological Quarterly, Iowa: The University of Iowa, v. 63, n. 1, p. 125-129. Inverno de 1984.

SMITH, Frederik N. (ed.) The Genres of “Gulliver's Travels”. Newark: University of Delaware Press, 1990.

STEVENSON, Lionel. The English Novel. Londres: Constable and Company, 1961.

SUTHERLAND, James. English Satire. Cambridge: Cambridge University Press, 1958.

TERRY, Richard. "Swift and Lying”. Philological Quarterly, Iowa: The University of Iowa, v. 73, n. 2, p. 243-265. Primavera de 1994.

TORCHIANA, Donald T. "Jonathan Swift, the Irish, and the Yahoos: The Case Reconsidered”. Philological Quarterly, Iowa: The University of Iowa, v. 54, n. 1, p. 195-211. Inverno de 1975.

VASCONCELOS, Sandra Guardini T. Dez lições sobre o romance inglês do século XVIII. São Paulo: Boitempo, 2002. 
WAGENKNECHT, Edward. Cavalcade of the English Novel. Nova Iorque: Henry Holt and Company, 1944.

WATT, Ian. A Ascensão do Romance. Tradução de Hildegard Feist. São Paulo: Companhia das Letras, 1991.

WILLIAMS, Kathleen. Swift - The Critical Heritage. Londres: Routledge \& Kegan Paul, 1970.

\section{Obras Literárias Complementares}

Anônimo. Arden of Faversham. Edição de Martin White. Nova Iorque: W. W. Norton \& Co., 1982.

Anônimo. Lazarillo de Tormes. Prólogo de Francisco Rico. Barcelona: Plaza \& Janes, 1997.

APULEIO [APULEIUS]. The Golden Ass. Edição e introdução de E. J. Kenney. Londres: Penguin Books, 1998.

ARBUTHNOT, John. The History of John Bull. Mclean, IndyPublish, s/d.

ARISTÓTELES, HORÁCIO, LONGINO. A Poética Clássica. São Paulo: Cultrix, 1997.

BEHN, Aphra. Love-Letters between a Nobleman and His Sister. Edição e introdução de Janet Todd. Londres, Penguin Books, 1996.

. Oroonoko and Other Writings. Edição e introdução de Paul Salzman. Oxford: Oxford University Press, 1994.

BOSWELL, James. Life of Johnson. Chicago: William Benton, Encyclopædia Britannica, Inc., 1952.

BRUCE, Susan (ed.). Three Early Modern Utopias. Utopia; New Atlantis; The Isle of Pines. Oxford, Oxford University Press, 1999.

BUNYAN, John. The Pilgrim’s Progress. Edição e introdução de Roger Sharrock. Londres: Penguin Books, 1987. 
BUTLER, Samuel. Erewhon. Edição e introdução de Peter Mudford. Londres: Penguin Books, 1985.

CAMPANELlA, Tommaso. A Cidade do Sol. São Paulo: Abril, 1974. (Coleção Os Pensadores.)

CAVENDISH, Margaret. The Blazing World and Other Writings. Edição de Kate Lilley. Londres: Penguin Books, 1992.

ROJAS, Fernando de. A Celestina. Tradução de Paulo Hecker Filho. Porto Alegre: Sulina, 1990.

CERVANTES, Miguel de. Dom Quixote de la Mancha. Tradução dos Viscondes de Azevedo e Castilho. São Paulo: Atena, sem data.

. Los Trabajos de Persiles y Sigismunda. Madri: Clásicos Castalia, 1969.

CONGREVE, William. The Comedies of William Congreve. Edição e introdução de Eric Rump. Londres: Penguin Books, 1985.

CYRANO DE BERGERAC, Savinien. Voyage dans la Lune. Paris: Flammarion, 1997.

. Les États et Empires du Soleil. Paris: Flammarion, 2003.

DAMPIER, William. A New Voyage Round the World. Nova Iorque: Dover, 1968.

DEFOE, Daniel. A Journal of the Plague Year. Edição crítica de Paula Backscheider. Londres: W. W. Norton \& Company, 1992. Outras edições: A Journal of the Plague Year. Edição e prefácio de Anthony Burgess. Londres: Penguin Books (1986). A Journal of the Plague Year. Edição e prefácio de Louis A. Landa. Oxford: Oxford University Press (1969).

. A Tour Through the Whole Island of Great Britain. Introdução e edição de Pat Rogers. Londres: Penguin Books, 1986.

. Capitain Singleton. Introdução de Penelope Wilson. Oxford: Oxford University Press, 1990.

. Coronel Jack. Tradução de Geir Campos. Rio de Janeiro: Francisco Alves, sem data. 
. Memoirs of a Cavalier. Introdução de John Mullan. Oxford: Oxford University Press, 1991.

. Moll Flanders. Edição e introdução de David Blewett. Londres: Penguin Books, 1989.

. Robinson Crusoe. Edição e introdução de John Richetti. Londres: Penguin Books, 2001.

. Roxana. Introdução de David Blewett. Londres: Penguin Books, 1987.

. “The Apparition of Mrs. Veal”, in English Literature 1650-1800 (Nova Iorque: J. B.

Lippincott Company, 1940). John C. Medenhall (ed.)

. The Best of Defoe's Review. Seleção de William L. Payne e introdução de Marjorie Nicholson. Nova Iorque: Barnes and Noble, 1971.

. "The True and Genuine Account of the Life and Actions of the Late Jonathan Wild." In: FIELDING, Henry. Jonathan Wild. Edição e introdução de David Nokes. Londres: Penguin Books, 1986.

. The True-Born Englishman and Other Writings. Edição e introdução de P. N. Furbank e W. R. Owens. Londres: Penguin Books, 1997.

DEKKER, Thomas. “The Shoemaker’s Holiday”. In: Eight Famous Elizabethan Plays. Nova Iorque: Modern Library, 1932.

DIDEROT, Les Deux Amis de Bourbonne et autres contes. Paris, Gallimard, 2002.

DUNN, Esther Cloudman (ed.). Eight Famous Elizabethan Plays. Nova Iorque: Modern Library, 19xx.

ELLEDGE, Scott (ed.). Eighteenth-Century Critical Essays. Ithaca: Cornell University, 1966.

FÉNELON, François de Salignac de la Mothe-. Les Aventures de Télémaque. Edição de Jacques Le Brun. Paris: Gallimard, 1995.

FIELDING. Henry. A Journey From This World to the Next and The Journal of a Voyage to Lisbon. Edição e introdução de Ian A. Bell e Andrew Varney. . Amelia. Edição e introdução de David Blewett. Londres: Penguin Books, 1987. 
. Jonathan Wild. Edição e introdução de David Nokes. Londres: Penguin Books, 1986. . Joseph Andrews / Shamela. Edição e introdução de Judith Hawley. Londres: Penguin Books, 1999.

. Tom Jones. Tradução de Octavio Mendes Cajado. São Paulo: Círculo do Livro, 1995.

FURETIÈRE, Antoine. Le Roman Bourgeois. Edição de Jacques Prévot. Paris: Gallimard, 1981.

GALLAND, Antoine (Trad.). Les Mille et Une Nuits; Paris, Éditions Garnier Frères, 1955,

GAY, John. The Beggar's Opera. Edição de Bryan Loughrey e T. O. Treadwell. Londres: Penguin Books, 1986.

GOLDSMITH, Oliver. The Vicar of Wakefield. Edição e introdução de Arthur Friedman. Oxford: Oxford University Press, 1999.

HAMMOND, Paul. Restoration Literature: An Anthology. Oxford: OUP, 2002.

HELIODORO [HELIODORUS]. Ethiopian History. Tradução do grego de Sir Walter Lamb. Edição e introdução de J. R. Morgan. Londres: Everyman, 1997.

JOHNSON, Samuel. Lives of the Poets. 2 v. Londres: Oxford University Press, 1952. . The History of Rasselas, Prince of Abyssinia. Introdução de Michael Irvin. Ware: Wordsworth Editions Limited, 2000.

LAFAYETTE, Madame de. La Princesse de Clèves. Paris: Garnier-Flammarion, 1966.

LAWRENCE, Robert G. (ed.) Restoration Plays. Londres: Everyman, 1999.

LE SAGE, Alain-René. Le Diable Boiteux. In Romanciers du XVIIIe Siècle. Coleção Bibliothèque de la Pléiade, v. 144. Bruxelas, Gallimard, 1996.

LENNOX, Charlotte. The Female Quixote. Oxford: OUP, 1989.

LINDSAY, David W. (ed.) The Beggar's Opera and Other Eighteenth Century Plays. Londres: Everyman, 1998. 
LONGO [LONGUS]. Daphnis et Chloé. Edição e tradução do grego de Aline TalletBonlavot. Paris: Flammarion, 1999.

LUCIANO DE SAMÓSATA. Histoire Vraie. Paris, Librarie Garnier Frères, 19xx.

MACKENZIE, Henry. The Man of Feeling. Oxford: OUP, 2001.

MANLEY, Delarivier. New Atalantis. Edição e introdução de Ros Ballaster. Londres: Penguin Books, 1992.

MONTESQUIEU. Lettres Persanes. Paris, Le Livre de Poche, 1995.

_. O Espírito das Leis. São Paulo, Martins Fontes, 2000.

MORE, Sir Thomas. Utopia. Tradução (da versão em inglês) de Jefferson Luiz Camargo e Marcelo Brandão Cipolla. São Paulo: Martins Fontes, 1999.

MORRIS, William. News From Nowhere and Other Writings. Londres: Penguin, 1998.

NASHE, Thomas. The Unfortunate Traveller and Other Works. Edição e introdução de J. B. Steane. Londres: Penguin Books, 1985.

ORWELL, George. Nineteen Eighty-Four. Londres: Penguin, 2003.

PEPYS, Samuel. The Diary of Samuel Pepys. Londres: Everyman / J. M. Dent \& Sons, sem data.

PETRÔNIO [PETRONIUS]. Satyrica. Tradução do latim e introdução de R. Bracht Branham e Daniel Kinney. Londres: Everyman, 1997.

PLATÃO. A República. Tradução de Enrico Corvisieri. São Paulo: Nova Cultural, 2000.

POPE, Alexander. Selected Poetry. Edição de Pat Rogers. Oxford: Oxford University Press, 1998.

PRAZ, Mario (ed.). Three Gothic Novels. The Castle of Otranto; Vathek; Frankenstein. Londres: Penguin Classics, 1986.

QUEVEDO, Francisco de. El Buscón. Edição de Domingo Ynduráin. Madri: Catedra, 2000.

RABELAIS, François. Gargantua. Prefácio de Michel Butor. Paris: Gallimard, 1969. . Pantagruel. Prefácio de Michelet. Paris: Gallimard, 1964. 
RICHARDSON, Samuel. Pamela; or, Virtue Rewarded. Introdução de Margaret A. Doody. Londres: Penguin Books, 1985.

. Clarissa: or The History of a Young Lady. Edição e introdução de Angus Ross. Londres: Penguin Books, 1986.

SAINTSBURY, George (ed.). Shorter Elizabethan Novels. Londres: J. M. Dent \& Sons, 1953.

SALZMAN, Paul (ed.). An Anthology of Elizabethan Prose Fiction. Oxford: Oxford University Press, 1987.

. An Anthology of Seventeenth-Century Fiction. Oxford: Oxford University Press, 1991.

SCARRON, Paul. Le Roman Comique. Edição de Yves Giraud. Paris: Flammarion, 1981.

SMOLLETT, Tobias.. The Adventures of Ferdinand Count Fathom. Edição e introdução de Paul-Gabriel Boucé. Londres: Penguin Books, 1990.

. The Adventures of Roderick Random. Oxford: OUP, 1999.

. The Expedition of Humphry Clinker. Edição e introdução de Lewis M. Knapp. Oxford: Oxford University Press, 1998.

. The Life and Adventures of Sir Launcelot Graves. Edição e introdução de Peter Wagner. Londres: Penguin Books, 1988.

SOREL, Charles. Histoire Comique de Francion. In Romanciers du XVIIe Siècle. Coleção Bibliothèque de la Pléiade. Paris, Gallimard, 1958.

STEELE, Richard, e ADDISON, Joseph. Selections from the Tatler and the Spectator. Edição e introdução de Angus Ross. Londres: Penguin Books, 1988.

STERNE, Laurence. A Sentimental Journey; The Journal to Eliza; A Political Romance. Oxford: Oxford University Press, 1998.

. A vida e as opiniões do cavalheiro Tristram Shandy. Tradução e introdução de José Paulo Paes. São Paulo: Companhia das Letras, 1998.

THACKERAY. “The English Humourists of the Eighteenth Century.” In: The Complete Works of William Makepeace Thackeray. Vol. XIII. Boston: Houghton, 
Mifflin and Company, 1889. p. 111-330.

The History of Henry Esmond. Nova Iorque: Modern Library, s/d.

VOLTAIRE. Lettres Philosophiques. Edição de Frédéric Deloffre. Paris: Gallimard, 1986.

WOMERSLEY, David (ed.). Augustan Critical Writing. Londres: Penguin Books, 1977.

\section{Literatura Complementar}

AITKEN, George Atherton. “Arbuthnot and Lesser Prose Writers”. In: The Cambridge History of English Literature, v. 9 - From Steele and Addison to Pope and Swift. Cambridge: Cambridge University Press, 1934. P. 129-145.

ALKON, Paul K. "Literary Criticism and Intellectual Foregrounds”. Philological Quarterly, Iowa: The University of Iowa, v. 55, n. 4, p. 553-566. Outono de 1976.

ATKINS, J. W. H. English Literary Criticism: $17^{\text {th }}$ and $18^{\text {th }}$ centuries. Londres: Methuen, 1951.

AUERBACH, Erich. Mimesis. A Representação da Realidade na Literatura Ocidental. São Paulo, Edusp/Perspectiva, 1971.

BACKSCHEIDER, Paula. Daniel Defoe: His Life. Baltimore: John Hopkins University Press, 1989.

BAKHTIN, Mikhail. A Cultura Popular na Idade Média e no Renascimento. Brasília/São Paulo: EUB, Huticec: 1987

BOOTH, Wayne C. The Rhetoric of Fiction. $2^{\mathrm{a}}$ edição. Londres: Penguin Books, 1991.

BURGESS, Anthony [John Burgess Wilson]. English Literature. A Survey for Students. Londres: Longmans, 1966.

CALLAN, Norman. (1957) “Alexander Pope”. In: FORD, Boris (ed.). The New Pelican Guide to English Literature 4. From Dryden to Johnson. Londres: Penguin Books, 1997. p. 235-254.

CALVINO, Italo. Por que ler os clássicos. Tradução de Nilson Moulin. São Paulo, Companhia das Letras, 1995. 
CARTER, Ronald, e McRAE. John, History of Literature in English. Londres: Routledge, 1998.

COLLINS, A. S. (1957) “Language 1660-1784”. In: FORD, Boris (ed.). The New Pelican Guide to English Literature 4. From Dryden to Johnson. Londres: Penguin Books, 1997. 165-181.

CULLER, Jonathan. Teoria literária: uma introdução. Tradução de Sandra Vasconcelos. São Paulo: Beca, 1999.

DAICHES, David. A Critical History of English Literature, v. II. Londres: Secker \& Warburg, 1960.

DOBRÉE, Bonamy. English Literature in the Early Eighteenth Century - 1700-1740. Oxford: Clarendon Press, 1959.

DURANT, Will, e DURANT, Ariel.. A Era de Voltaire. Tradução de Antônio Carlos Gonçalves Penna. Rio de Janeiro: Record, sem data.

EAGLETON, Terry. Teoria da Literatura. Uma Introdução. Tradução de Waltensir Dutra. São Paulo: Martins Fontes, 2001.

FORSTER, Edward Morgan. Aspects of the Novel. Londres: Penguin Books, 1964.

HAUSER, Arnold. (1953) História Social da Arte e da Literatura. Tradução de Álvaro Cabral. São Paulo: Martins Fontes, 2000.

HORNE, C.J. (1957) “Literature and Science”. In: FORD, Boris (ed.). The New Pelican Guide to English Literature 4. From Dryden to Johnson. Londres: Penguin Books, 1997. p. 135-150.

HUMPHREYS, Arthur. (1957) “The Social Setting” e “The Literary Scene”. In: FORD, Boris (ed.). The New Pelican Guide to English Literature 4. From Dryden to Johnson. Londres: Penguin Books, 1997. p. 15-100.

. The Augustan World - Life and Letters in Eighteenth Century England (Londres: Methuen \& Co. Ltd., 1964)

HYLAND, Paul, e SAMMELLS, Neil (ed.). Writing and Censorship in England (London, Routledge, 1992) 
IRWIN, W. R. “Swift the Verse Man”. Philological Quarterly, Iowa: The University of Iowa, v. 54, n. 1, p. 222-238. Inverno de 1975.

JACK, Ian. Augustan Satire. Intention and Idiom in English Poetry. 1660-1750. Oxford, OUP, 1942.

JACK, Jane H. (1957) “The Periodical Essayists”. In: FORD, Boris (ed.). The New Pelican Guide to English Literature 4. From Dryden to Johnson. Londres: Penguin Books, 1997. p. 182-194.

KENYON, J. P. (1978) Stuart England. Londres: Penguin Books, 1990.

LOCKYER, Roger. Tudor and Stuart Britain. Londres: Longman, 1967.

McCUTCHEON, Roger P. Eighteenth-Century English Literature. Londres: Oxford University Press, 1985.

MORGAN, Kenneth O. (ed.) The Oxford Illustrated History of Britain. Oxford: Oxford University Press, 1992.

MUIR, Edwin. The Structure of the Novel. Londres: The Hogarth Press, 1957.

NISBETT, H. B., e RAWSON, Claude (ed.). The Eighteenth Century. The Cambridge History of Literary Criticism, V. 4. Cambridge, CUP, 1997.

NORTON, Glyn P. (ed.). The Renaissance. The Cambridge History of Literary Criticism, V. 3. Cambridge, CUP, 2001.

PALLARES-BURKE, Maria Lúcia Garcia. The Spectator. O Teatro das Luzes. Diálogo e Imprensa no Século XVIII. São Paulo: Hucitec, 1994.

PARK, William. “Change in the Criticism of the Novel after 1760”. Philological Quarterly, Iowa: The University of Iowa, v. 46, n. 1, p. 34-41. Janeiro de 1967.

PLUMB, John Harold. England in the Eighteenth Century. Londres: Viking Penguin, 1951.

POMEAU, René, e EHRARD, Jean. De Fénelon à Voltaire. Paris: Flammarion, 1998.

ROGERS, Pat. “Books, Readers and Patrons”. In: FORD, Boris (ed.). The New Pelican Guide to English Literature 4. From Dryden to Johnson. Londres: Penguin Books, 1997. p. 214-227. 
. The Context of English Literature — The Eighteenth Century. Londres: Methuen, 1978.

SAMPSON, George. The Concise Cambridge History of English Literature. Cambridge, Cambridge University Press, 1970.

SUTHERLAND, James. English Literature in the Late Seventeenth Century. Oxford: Clarendon Press, 1969.

TREVELYAN, G. M.. History of England. Londres: Longmans, Green and Co., 1948.

. "William and Mary” e “The Reign of Anne”. In: England Under the Stuarts. Londres: Methuen \& Co. Ltd., 1949. p. 371-430.

TROLANDER, Paul, e TENGER, Zeynep. “Criticism Against Itself: Subverting Critical Authority in Late-Seventeenth-Century England”. Philological Quarterly, Iowa: The University of Iowa, v. 75, n. 3, p. 311-338. Verão de 1996.

WARD, A. C. Illustrated History of English Literature, v. II. Londres: Longsman, Green \& Co., 1954.

WATT, Ian. Mitos do Individualismo Moderno. Tradução de Mario Pontes. Rio de Janeiro: Jorge Zahar, 1997.

WEINBROT, Howard D. Augustus Caesar in “Augustan” England. Princeton, PUP, 1978.

WHEELER, Michael. English Fiction of the Victorian Period. Nova Iorque: Longman, 1994.

WILLIAMS, Basil. The Whig Supremacy: 1714-1760. The Oxford History of England, XI. Oxford, OUP, 1939.

WILliAMS, Raymond. O Campo e a Cidade. Tradução de Paulo Henriques Britto. São Paulo, Companhia das Letras, 1990.

WOOLF, Virginia. The Common Reader. Londres: Hogarth Press, 1957.

ZUBER, Roger, e CUÉNIN, Micheline. Le Classicisme. Paris: Flammarion, 1998. 